\title{
Э.Я. Вафин
}

\section{Золотые слова}

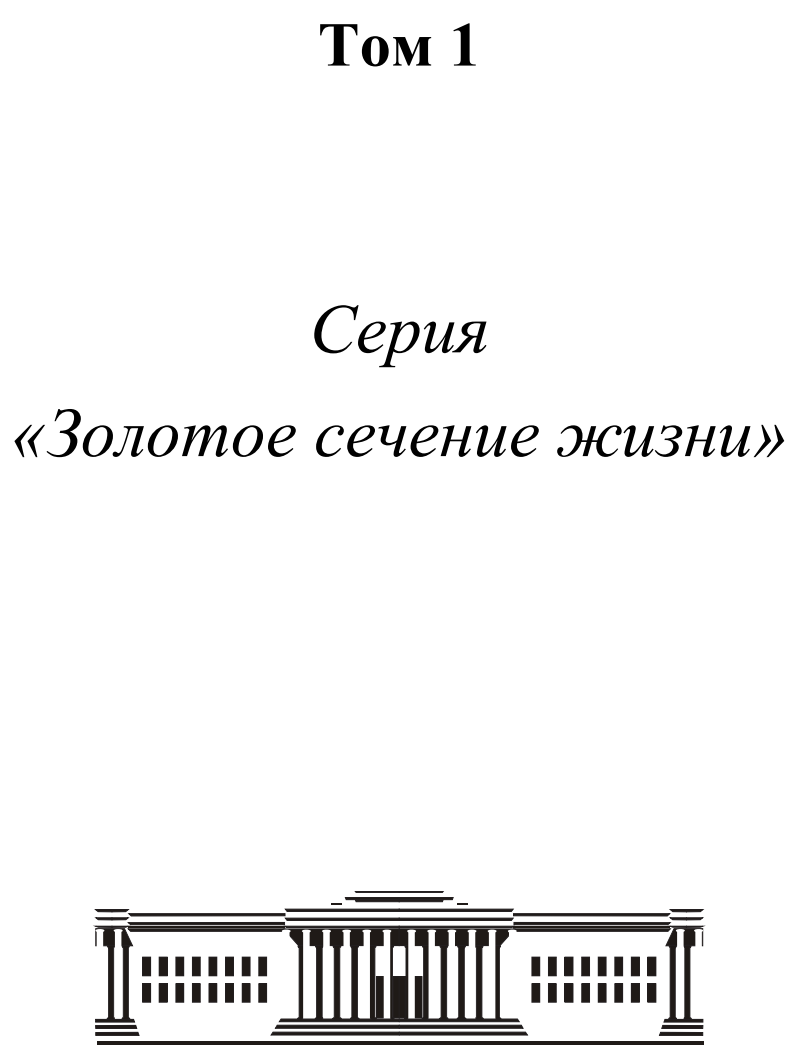

КАЗАНСКИЙ ФЕДЕРАЛЬНЫЙ УНИВЕРСИТЕТ 2017 


\section{УДК 398}

\section{ББК 82}

B21

\section{Вафин Э.Я.}

В21 Золотые слова / авт.-сост. Э.Я. Вафин. - Казань: Изд-во Казан. ун-та, 2017. - Т. 1. - 196 с. (Серия «Золотое сечение жизни»).

Эта книга - первая из серии «Золотое сечение жизни». Авторсоставитель начиная еще со студенческих лет собрал множество теплых слов, произнесенных на различных праздничных мероприятиях: как придуманных лично, так и заимствованных из книг и Интернета. Под одной обложкой объединены понравившиеся, собранные в течение 20 лет поздравления к различным приятным событиям, которые сопровождают нас на протяжении всей жизни. Это издание позволит читателю с легкостью подобрать подходящие слова к любому торжественному мероприятию. 


\section{Оглавление}

Вступительное слово ...................................... 5

Универсальные тосты ........................................... 6

Притчи .......................................................... 12

Торжественные мероприятия ….............................. 27

День рождения …...................................... 27

Поздравление Коллеге ..................................... 27

Поздравление Женщине ................................. 35

Поздравление Руководителю ............................ 44

Именные .................................................. 55

Поздравление Мужчине ..................................... 60

Поздравление Родственникам ................................ 64

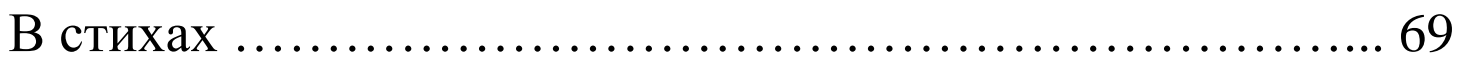

Юбилей ................................................... 73

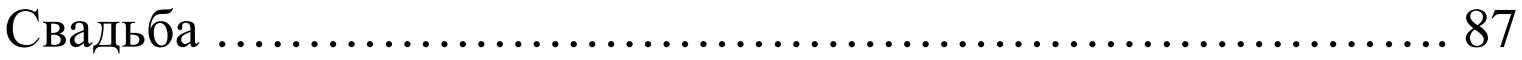

Рождение ребенка .......................................... 101

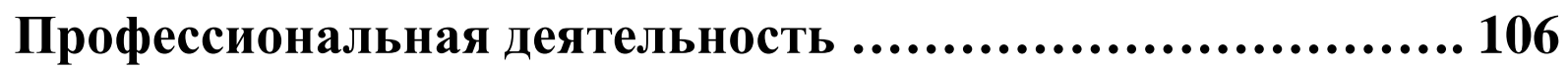

Назначение на должность .................................... 106

Проводы на пенсию .......................................... 109

Руководителю на годовщину пребывания в должности ...... 111

День рождения / юбилей организации ...................... 113

Завершение трудовой деятельности ........................ 118

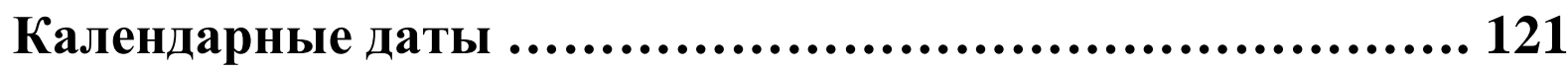

Январь …................................................ 121

Новый год / 1 января ................................... 121

Старый Новый год / 13 января ........................... 132

Татьянин день. День российского студенчества /

25 января ............................................ 139

Февраль ...................................................... 140

День святого Валентина. День всех влюбленных /

14 февраля .............................................. 140 
День защитника Отечества / 23 февраля .................. 143

Март ........................................................... 149

Международный женский день / 8 марта ................ 149

Апрель ..................................................... 158

День смеха / 1 апреля ..................................... 158

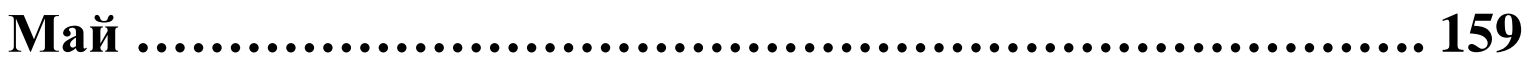

Праздник весны и труда / 1 мая .......................... 159

День Победы в ВОВ 1941-1945 / 9 мая ................... 162

Последний звонок / 25 мая .............................. 165

Июнь ...................................................... 168

Международный день защиты детей / 1 июня ............. 168

День социального работника / 8 июня .................... 169

День России / 12 июня .................................... 171

День медицинского работника / 19 июня ................. 178

День молодежи / 27 июня ................................ 179

Июль ......................................................... 179

День российской почты / 2-е воскресенье июля .......... 179 День ГИБДД МВД РФ / 3 июля ........................... 179

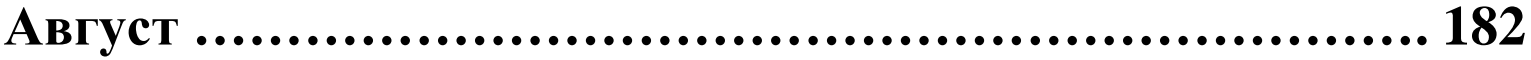

День города ........................................... 182

Сентябрь ...................................................... 182

День знаний / 1 сентября ................................. 182

День финансиста / 8 сентября ........................... 183

Октябрь ....................................................... 184

Международный день пожилых людей / 1 октября ...... 184

День российского страховщика / 6 октября ............... 188

Ноябрь ........................................................ 190

День народного единства / 4 ноября ...................... 190

Международный день бухгалтера / 16 ноября ............. 191

Декабрь ........................................................... 193

День Конституции РФ / 12 декабря ..................... 193 


\section{Вступительное слово}

Хорошая застольная речь - всегда импровизация, ее слова всегда свежи и остроумны. Импровизация импровизацией, но, как известно, лучший экспромт тот, который заготовлен заранее.

Тост - слово из английского языка и обозначает слегка обжаренный ломтик хлеба. В старину жители Британских островов, прежде чем выпить вино или какой-либо более крепкий напиток, окунали в него поджаренный на огне ломтик хлеба, чтобы напиток впитал в себя также и хлебный аромат. Впоследствии традиция окунать хлеб в вино забылась, но возникла другая: произносить тост, перед тем как выпить вина.

В этой книге, первой из серии «Золотое сечение жизни», я, начиная еще со студенческой скамьи, собрал множество теплых слов, произнесенных на различных праздничных мероприятиях: как придуманных лично мной, так и заимствованных из книг и Интернета.

Названием серии хотелось показать гармоничную взаимозависимость разных этапов жизни, в течение которой один жизненный этап относится к другому, как вся жизнь к самому ее (жизни) началу. Немного запутанно, но, наверное, станет понятнее, если вы внимательно посмотрите на обложку. Поэтому и содержание имеет свою цель - объединить под одной обложкой понравившиеся, собранные в течение 20 лет поздравления к различным приятным случаям, которые сопровождают нас на протяжении всей жизни. Надеюсь, читатели найдут их интересными и обязательно подберут для себя подходящие теплые слова или даже целый тост. А я, в свою очередь, отметил понравившиеся мне.

Разумеется, весь собранный за долгие годы материал не уместится и в нескольких томах, поэтому продолжение, очевидно, будет... 


\section{Универсальные тосты}

Произнести хороший тост - задача не из легких. Мне бы не хотелось ограничиваться краткими высказываниями в стиле: «Ну, за встречу!», «За молчание!» и так далее Хочется произнести свежий и оригинальный тост, чтобы поддержать атмосферу праздничного веселья, ведь хороший тост становится изюминкой всего торжества.

Первоначально тостам приписывали магическую силу: вино приносили в храмы, там люди произносили молитвы, говорили о своих желаниях, а затем выпивали вино. Именно с тех пор живет в народе поверье, что после тоста ставить бокал на стол нельзя, необходимо его выпить, в таком случае желание обязательно сбудется.

$* * *$

Обычай чокаться бокалами появился в те далекие времена, когда не считалось серьезным грехом подсыпать яду в бокалы гостей или соседей за столом. Поэтому, чтобы заверить гостей в своем миролюбии, хозяин не только наливал немного вина сначала в свой бокал и выпивал его, но и все гости в ходе застолья неоднократно «обменивались вином», то есть отливали из своего бокала в бокал соседа, а затем символически соединяли бокалы чокались.

В нынешнее время угроза отравлений не является столь актуальной, поэтому предлагаю поднять бокалы и выпить за здоровье присутствующих!

\section{$* * *$}

Один мой приятель давно уже собирался полететь в космос, другой - выучить китайский язык, третий - бросить курить. 
Но до сих пор первый так и ходит по Земле, второй не знает ни одного иероглифа, а третий так и дымит как паровоз. И знаете почему? Потому что все они пытались начать новую жизнь с понедельника, а в году их целых 52, и они не знали какой именно из них выбрать.

Но мы с Вами прекрасно умеем расставлять приоритеты, добиваясь своих целей. И каждый понедельник мы ставим перед собой новые амбициозные креативные проекты и воплощаем их в жизнь! Невозможное возможно - вот наш девиз! Предлагаю за это выпить!

$$
* * *
$$

Кобру спросили:

- Почему, когда ты ужалишь человека - гибнет человек, а если пчела ужалит человека - гибнет пчела?

- Все зависит от степени квалификации. Пчела дилетант, а я - профессионал.

Так выпьем же за профессионализм в любом деле!

Пожалуй, одна из самых поразительных особенностей жизни в том, насколько по разному каждый из нас к ней относится. Проанализировав огромную массу научной информации, английский психолог и антрополог Дэниэль Нетл сделал удивительные умозаключения. Поделюсь лишь главным выводом - никакой «наилучшей» личности в природе не существует, то есть каждая наша особенность в определенных обязательствах нам невероятно выгодна. 
Так выпьем же за то, чтобы мы лучше знали свои личные особенности и максимально их использовали в достижении своих целей!

Предлагаю тост за неоднозначность нашей жизни.

Мир состоит не только из черного и белого цветов, приходиться учиться находить компромиссы, изменяться, учиться, расти, становиться мудрее, восприимчивее, сильнее.

Вот например, иногда быть сильным - это не делать ничего, приложить силу - значит проявить слабость.

Главная мудрость жизни - это мудрость уместности, выпьем за то, чтобы мы все в совершенстве овладели этим искусством!

$* * *$

Хочу поднять тост за то, чтобы не расстраиваться из-за каждой мелочи!

Решили как-то два жулика магазин ограбить. Тщательно все спланировали. Дождались ночи, вскрыли замок, обчистили кассу и хотели уже уходить. Как вдруг у одного из них карман порвался, и оттуда мелочь высыпалась. Второй его торопит: «Идем», говорит, а он отвечает: «Погоди, сейчас мелочь соберу!». Ну, пока он собирал, милиция и приехала. Так что весь их тщательный план расстроился. Так выпьем за то, чтобы не расстраиваться из-за всякой мелочи!

\section{$* * *$}

Один народный мудрец сказал: «Дайте мне точку опоры и я произнесу тост». Как известно, для того, чтобы выпить, надо решить 2 фундаментальные проблемы - на какие деньги и по 8 
какому поводу? Устранение первой проблемы автоматически является поводом и разрешает вторую проблему. Как говорят ирландцы, лучше потратить деньги так, как будто у Вас нет завтра, чем провести вечер так, как будто у Вас нет денег.

Хочу блеснуть эрудицией и произнести английский тост Healthy, wealthy, stealthy! - Это пожелание здоровья, богатства и изворотливости, или умения находить выход из любой ситуации с выгодой для себя.

Слепому кажется, что его не видят. Глухому кажется, что его не слышат. Эгоисту кажется, что его никто не любит. За нашего руководителя! Он у всех у нас на слуху, на виду и в сердце!

\section{$* * *$}

Ползла жаба через рельсы. Проехал поезд и оторвал ей ноги. Отползла жаба в сторону и подумала: «Красивые были ноги, надо вернуться». Только она залезла под рельсу, как опять поезд проехал и отрезал ей голову. Так выпьем же за то, чтобы не терять головы из-за красивых ног.

$* * *$

Один проповедник трезвости обратился к своим слушателям:

- Несчастные, знайте же, что вы пали ниже животных. Ну, поставьте перед ослом два ведра: одно с водой, другое с вином. Что он будет пить?

- Конечно, воду! - ответили многие слушатели.

- Вот именно: воду. А почему?

- Потому, что он осел! - послышался дружный ответ.

Не уподобимся же и мы ослам неразумным! 


\section{*** $*$}

Мой прадед говорил: «Я имею желание купить дом, но не имею возможности. Я имею возможность купить козу, но не имею желания». Так давайте выпьем за то, чтобы наши желания совпадали с нашими возможностями!

Великий философ Л. Фейербах сказал, что жизнью следует наслаждаться как превосходным вином, глоток за глотком, с передышкой. Даже лучшее вино теряет для нас всякую прелесть, мы перестаем его ценить, когда пьем как воду.

Так давайте же выпьем за то, что у нас у всех есть вкус к жизни и мы всегда им наслаждаемся!

Великий философ А. Шопенгауэр утверждал, что с точки зрения молодости жизнь есть бесконечно долгое будущее; с точки зрения старости - очень короткое прошлое. Великая наука жить счастливо состоит в том, чтобы жить в настоящем, не жалеть о прошлом и не бояться будущего. Давайте выпьем за это!

\section{$* * *$}

Пессимист видит трудности при каждой возможности; оптимист в каждой трудности видит возможности. Считают, что успех приходит к тем, кто рано встает. Нет: успех приходит к тем, кто встает в хорошем настроении. Так давайте же выпьем за то, чтобы мы всегда были в хорошем расположении духа, что будет лучшим доказательством мудрости! 
Какой-то мудрец сказал, что чем меньше мы гонимся за удовольствиями, за счастьем, чем больше заняты делом своей жизни, тем больше счастья мы находим, ведь счастье - свобода в настоящем, удовлетворение прошлым, надежда на будущее. Так давайте же выпьем за то, чтобы все мы овладели искусством быть счастливым!

\section{$* * *$}

Немецкий философ XVIII века Георг Кристофер Лихтенберг сказал: «Долг каждого мудреца - видеть в сапожнике короля, воздавать должное всякому по заслугам и ценить величие души, талант и способности не только по шумным эффектам». Я предлагаю поднять наши бокалы за то, чтобы мы всегда были подобными мудрецами, и тогда, как и сегодня, у нас будет много настоящих друзей и все больше и больше удачи.

\section{$* * *$}

В одной притче, описанной Кафкой, говорится о человеке, который стоял перед раскрытыми воротами и не решался в них войти, поскольку возле них застыли в молчании суровые стражи. Человек думал, что воины не пропустят его. Прошло время, и ворота закрылись. Тогда один из стражей сказал человеку:

- Чудак, эти ворота были открыты специально для тебя, и только тебя мы должны были пропустить.

Так давайте же выпьем за то, чтобы не боятся входить в свои ворота и никогда не упускать свой шанс. 


\section{Притчи}

На задворках Вселенной находился один магазинчик. Вывески на нем давно уже не было - ее куда-то унесло ураганом, а новую хозяин не стал прибивать, потому что каждый местный житель и так знал, что магазин продает желания.

Ассортимент магазина был огромен, здесь можно было купить практически все: огромные яхты, квартиры, замужество, пост вице-президента корпорации, деньги, детей, любимую работу, красивую фигуру, победу в конкурсе, большие машины, власть, успех и многое-многое другое. Не продавались только жизнь и смерть - этим занимался головной офис, который находился в другой галактике.

Каждый пришедший в магазин (а ведь есть и желающие, которые ни разу не зашли в магазин, а остались сидеть дома и просто желать) в первую очередь узнавал цену своего желания.

Цены были разные. Например, любимая работа стоила отказа от стабильности и предсказуемости, готовности самостоятельно планировать и структурировать свою жизнь, веры в собственные силы и разрешения себе работать там, где нравится, а не там, где надо.

Власть стоила чуть больше: надо было отказаться от некоторых своих убеждений, уметь всему находить рациональное объяснение, уметь отказывать другим, знать себе цену (и она должна быть достаточно высокой), разрешать себе говорить «Я», заявлять о себе, несмотря на одобрение или неодобрение окружающих.

Некоторые цены казались странными - замужество можно было получить практически даром, а вот счастливая жизнь стоила 
дорого: персональная ответственность за собственное счастье, осознание собственной ценности и значимости, отказ от бонусов «жертвы», риск потерять некоторых друзей и знакомых.

Не каждый пришедший в магазин был готов сразу купить желание. Некоторые, увидев цену, сразу разворачивались и уходили. Другие долго стояли в задумчивости, пересчитывая наличность и размышляя, где бы достать еще средств. Кто-то начинал жаловаться на слишком высокие цены, просил скидку или интересовался распродажей.

А были и такие, которые доставали все свои сбережения и получали заветное желание, завернутое в красивую шуршащую бумагу. На счастливчиков завистливо смотрели другие покупатели, судача о том, что хозяин магазина - их знакомый, и желание досталось им просто так, без всякого труда.

Хозяину магазина часто предлагали снизить цены, чтобы увеличить количество покупателей. Но он всегда отказывался, так как от этого страдало бы и качество желаний.

Когда у хозяина спрашивали, не боится ли он разориться, то он качал головой и отвечал, что во все времена будут находиться смельчаки, готовые рисковать и менять свою жизнь, отказываться от привычной и предсказуемой жизни, способные поверить в себя, имеющие силы и средства для того, чтобы оплатить исполнение своих желаний.

А на двери магазина уже добрую сотню лет висело объявление: «Если твое желание не исполняется - оно еще не оплачено».

Надо быть смелее в этой жизни: и пробовать, и рисковать, и падать, и разбивать коленки ради любимого дела, ради любимой семьи, ради мечты! 
И не случайно мудрые говорят, что начало - половина дела. Самое сложное, как показывает жизненная практика, именно начать. Кто начинал - тот знает. Сдвинуться с места, с мертвой точки, сделать первый шаг к достижению поставленной цели... лишь начав, можно продвинуться дальше.

$* * *$

Три поросенка построили себе домики. Пришел волк к первому, посмотрел: стены дрянь, одна солома; дунул посильнее, все развалилось. Съел волк поросенка, пошел к другому. Смотрит, стены из прутьев, ерунда. Пнул ногой, пнул другой, домик развалился. Съел волк второго поросенка, пошел к последнему. А вот с последним вышел облом. Нет, дверь-то волк выбил и даже стенку как-то умудрился развалить. Но тут на него свалилась крыша.

Мораль: да будь ты хоть последней свиньей, главное иметь солидную крышу.

***

В одном городе жили-были слепцы. А у них, как водится, был поводырь - одноглазый. Слепцы его очень уважали и завидовали его умению все видеть.

А потом пришел в этот город великий лекарь, а может, добрая фея или вообще пророк какой-нибудь, и всех вылечил. Слепцы прозрели.

Они посмотрели на одноглазого, увидели, что он носит повязку, и тоже сделали себе такие же, потому что поводырю, конечно, лучше знать, одним глазом смотреть на мир или двумя он же такой опытный! 
Однажды вор залез в чужой курятник и украл курицу. Когда он убегал, то опрокинул фонарь, и курятник загорелся. Курица смотрела назад и, видя огонь пожара, понимала: вор спас ей жизнь.

Когда вор откармливал курицу пшеном и хлебом, курица понимала: вор о ней заботится.

Когда вор скитался из города в город, пряча курицу за пазуху, курица понимала: вор ее любит.

Когда курица увидела, что вор замахнулся ножом, она поняла: вор хочет покончить жизнь самоубийством. Она прыгнула на нож и прикрыла вора своим телом. И умерла счастливой. И вор тоже был счастлив. В общем, хэппи-энд.

Так выпьем же за правильное видение ситуации!

$* * *$

Однажды некий мастер стрельбы из лука узнал, что в соседней провинции живет мальчик, владеющий великим искусством. И действительно, когда он пришел в гости к этому мальчику, то увидел, что все стены разрисованы мишенями: демонами, духами, драконами - и в сердце каждой мишени торчит стрела.

- Удивительно! - воскликнул мастер лука. - Это действительно великое искусство!

- Хочешь, я и тебя научу? - спросил мальчик, улыбаясь. Все очень просто, я стреляю в стену, а потом рисую мишень.

Мастер сплюнул, выругался и пошел восвояси. Он ничего не понял.

Мальчик не был великим стрелком. Он был великим художником. 


\section{$* * *$}

В город пришел пророк и возвестил о Конце Света. Люди пришли в страшное возбуждение, целые толпы повалили в храмы, все принялись просить друг у друга прощения и замаливать грехи, богатые - срочно раздавать рубашки бедным, пьяницы выливать вино в реку, блудницы - уходить косяками в монастырь... Только один жадный торговец не присоединился ко всеобщему энтузиазму. Он вышел на крыльцо своего магазина и повесил на дверь табличку: «Распродажа по случаю Конца Сезона».

- Нечестивый! - закричал ему кто-то из толпы. - Даже в такую минуту ты думаешь лишь о наживе!

- Я не хочу лицемерить, - спокойно отозвался торговец. Перед лицом смерти я - такой, какой есть.

$* * *$

Три человека ворочали камни. Одного из них спросили:

- Что ты делаешь?

Он вытер пот со лба и ответил:

- Горбачусь.

Подошли ко второму и спросили:

- А ты что делаешь?

Он закатал рукава и деловито сказал:

- Деньги зарабатываю.

Спросили у третьего:

- А что делаешь ты?

Он посмотрел вверх и сказал:

- Храм строю.

Жизнь наполнена смыслом только у того, кто преследует великую цель. 
Пусть Ваша жизнь будет наполнена новыми достижениями, долгими годами, наполненной смыслом жизни, новыми победами, теплом и любовью дорогих Вам людей.

Орел сидел на дереве, отдыхал и ничего не делал. Маленький кролик увидел орла и спросил:

- А можно мне тоже сидеть, как Вы, и ничего не делать?

- Конечно, почему нет, - ответил тот.

Кролик сел под деревом и стал отдыхать. Вдруг появилась лиса, схватила кролика и съела его.

- Да, - подумал орел, - чтобы сидеть и ничего не делать, нужно сидеть очень и очень высоко.

\section{$* * *$}

- Папа, а почему мальчишки во дворе говорят, будто Деда Мороза не существует?

- Сынок... - сказал отец, усаживая сына себе на колени, ты уже большой мальчик, и, думаю, настало время признаться тебе... Видишь ли, этот старик с бородой, который каждый год приносил тебе подарки... так вот, это на самом деле был я.

- Папа! - воскликнул восторженно мальчик. - Папка! Я так и знал! Спасибо, папка, за то, что ты есть! Вот только... - он задумчиво нахмурил бровки, - я все-таки не понимаю, как ты умудряешься навестить за одну ночь двести миллионов детей?

\section{$* * *$}

- Учитель! Я вчера спрашивал, как мне быстро разбогатеть, а Вы сказали: «Купи лотерейный билет». Я купил, заполнил, но он не выиграл!

- Значит, ты его заполнил неправильно. 
Жил-был один богатый человек. И был у него слуга, который не первый год служил хозяину верой и правдой. Слуга у него был странный, всегда он говорил хозяину: «Все к лучшему!» Вот чтобы ни происходило, он то и дело повторял: «Все к лучшему!» Хозяин посмеивался над слугой, но был душевно к нему привязан...

Однажды, решив пойти на охоту, хозяин дал указание слуге - подготовить оружие.

Вот пришли они в лес, берет хозяин оружие, которое слуга предварительно подготовил и зарядил... Стреляет... И отстреливает себе большой палец на руке. Кричит, ругается на слугу, а слуга все повторяет: «Все к лучшему!»

Рассердился хозяин и приказал бросить слугу в подземелье на заточение до конца дней своих. Слуга не стал спорить и, не затаив обиды на своего хозяина, сказал: «Все к лучшему!»

Прошло много лет...

Однажды хозяин отправился в чужие страны... И попал в плен к чужеземцам - людоедам! Началась подготовка к церемонии праздничного ужина... Как вдруг один из членов племени заметил, что у их «ужина» не хватает пальца на руке.

Оказалось, что для чужеземцев отсутствие пальца на руке священный знак! И такого человека кушать нельзя ни в коем случае!

\section{Отпустили они пленника.}

Пришел хозяин домой, спустился в подземелье и говорит слуге: «Ты был прав - все к лучшему! Если бы я не отстрелил себе много лет назад палец, то меня бы уже не было! Но одного я не могу понять... Я тебя, своего верного мудрого слугу, заточил 
на долгие годы в подземелье. Что же в этом хорошего? Как же это к лучшему?»

А слуга отвечает: «Если бы ты не заточил меня в подземелье, то взял бы с собой на остров, где я был бы съеден чужеземцами, потому как у меня целы все пальцы...»

Впереди могут быть и падения, и провалы. Это бесценный опыт, все, что ни делается - все к лучшему, а результат ждет только того, кто начал свой путь и не останавливается на полпути.

$* * *$

Жила-была маленькая девочка. А у нее, как водится, были папа-мама.

Папа-мама говорили девочке: «Не ходи, девочка, в темный лес, там тебя волк покусает!»

Но девочка спокойно ходила в темный лес гулять, и никто ее ни разу не укусил.

Папа-мама говорили: «Не купайся, девочка, за буйками, на тебя нападет акула и съест!»

Но девочка всякий раз заплывала за буйки и никаких акул не встречала.

Папа-мама говорили: «Не качайся, девочка, на стуле, упадешь, зуб сломаешь!»

Девочка качалась на стуле, упала и сломала зуб.

Потому что родители не всегда ошибаются, иногда они бывают правы. Через два раза на третий. 
Герольд вышел на площадь, откашлялся и закричал:

- Как уже было объявлено, Их Величество Георг Тридесятый изволят скучать. В великой своей доброте и мудрости они велели устроить турнир лучших лжецов всего королевства для развлечения и увеселения. Тому, кто расскажет самую лучшую небылицу и самую наглую ложь, Их Величество даруют мешок золота и корову в придачу. Итак, турнир объявляется открытым. Начинайте!

Три дня и три ночи лучшие лжецы со всего королевства состязались в ловкости языка и изощренности фантазии. Но победителем, конечно, оказался... король.

Ибо то, что он может кому-то за просто так отдать мешок золота - есть самая гнусная ложь и самая наглая небылица.

\section{$* * *$}

Агх был гением среди людей. Он изобрел колесо. А потом тачку. Он научился разводить огонь, обжигать глину и плавить медь. Он построил дом из кирпичей. Он приручил собак и свиней. Он научил всему этому свое родное племя.

А потом пришли соседи, которые уже знали порох, и всех перебили. Агх был гением, это да. Но он родился не в свое время.

- Я хочу отдать это яблоко Вам, - Парис галантно поклонился Афродите. - Потому что, если Елена Прекрасная действительно прекрасна хотя бы вполовину, как вот Вы, мадам, - он кивнул Гере, - то это осчастливило бы меня не менее, чем Ваш, мадемуазель, поцелуй, - с этими словами он повернулся к Афине и покрылся румянцем смущения.

Богини озадаченно переглянулись.

- Выкрутился... - с досадой обронила Гера. 
- Смилуйся, государыня Рыбка! Старуха-то! Хочет быть Владычицей Морскою!

- Ну наконец-то! - прошептала Рыбка. - Свободна! Тысячу лет я этого ждала!

Всплеснула плавниками - и обернулась девицей-красавицей.

- Ну вот, - сказала она, выходя из воды, - теперь пусть твоя старуха вместо меня морем владеет.

$* * *$

У одного индуса жили три обезьяны: слепая, глухая и немая.

Однажды в дом забрался вор, увидел обезьян и собрался их убить, чтобы не оставлять свидетелей.

- Ничего не вижу! - поспешно сказала слепая обезьяна.

- Ничего не слышу! - добавила глухая.

А немая только руками развела: она, мол, и рада бы что-то сказать, да вот не может.

Вор успокоился, собрал всякое добро в мешок и убежал.

Утром хозяин обнаружил пропажу и вызвал полицию.

- Я все видела! - сказала глухая обезьяна.

- Я все слышала! - добавила слепая.

А я записала номер машины, - показала знаками немая и протянула листок.

Как часто нас подводят стереотипы!

$$
* * *
$$

- Послушай, а может, хватит? - спросил Буревестник.

Уж заложил очередной крутой вираж и приблизил голову к уху Буревестника. 
- Что ты понимаешь, птица! Для тебя летать - это норма жизни. А ты представь, что значит полет для рожденного ползать!

Буревестник только покачал головой. А Уж, крепко обвившийся вокруг его шеи, возносился все выше и выше...

$* * *$

- Создатель! - обратился Горшок к Гончару. - Вот ты меня сотворил из глины...

- Ну, сотворил.

- Я благодарю тебя. Но в чем смысл моего существования? Какая высшая цель? Зачем я вообще нужен?

- Что значит, зачем? Ты что, не рад, что ли?

- Я рад, конечно! Но я хотел бы знать...

- Нет уж, ты, пожалуйста, определись! Чего ты хочешь: знать или радоваться?

\section{$* * *$}

- Ну что, что мне сделать, чтобы ты, наконец, согласилась стать моей?!

- Достань мне луну с неба - соглашусь.

- Луну?

- Ага.

- Настоящую луну?

- Именно.

- Я достану! Обещаю!

И Он достал с неба луну, хотя это было трудно.

Падение луны вызвало ряд природных катаклизмов невероятной мощи, в результате которых погибли и Он, и Она, и все остальные динозавры.

Надо быть осмотрительнее в своих запросах. 


\section{$* * *$}

Один человек совершил преступление. Его поймали и привели на суд к королю. За его деяние полагалась смертная казнь, но король предложил ему самому выбрать свою судьбу: либо быть повешенным, либо попасть за большую, черную, страшную стальную дверь. Преступник подумал и выбрал виселицу.

Когда на шею ему накинули петлю, он вдруг сказал:

- Мне стало любопытно: что там, за той дверью?

Король рассмеялся:

- Да вот, понимаешь ли, забавная штука получается. Я всем предлагаю этот выбор, и все выбирают виселицу.

- А за дверью-то что? - допытывался преступник. - Я все равно никому не скажу, - добавил он, указывая на петлю.

Помолчав, король ответил:

- Там свобода. Но люди так боятся неизвестности, что предпочитают ей веревку!

Про мудрого человека люди говорили, что он видит суть любой вещи. Многие спрашивали у него совета. Два молодых человека поспорили о способностях учителя. Один из них утверждал, что поставит учителя в тупик своим вопросом. С утра юноша поймал бабочку и взял ее полотно в свои ладони. Он решил, подойдя к учителю, спросить, жива бабочка или мертва.

- Если учитель скажет, что жива, - размышлял юнец, я слегка сожму ладони и покажу всем мертвую бабочку. Если скажет, что мертва, то я разожму ладони, и бабочка взлетит. Так учитель попадет впросак, а я выиграю спор.

Подойдя к учителю в присутствии других людей, юноша спросил: 
- Учитель, жива бабочка или мертва у меня в ладонях? и услышал в ответ:

- Все в твоих руках...

$* * *$

Однажды ко льву пришел шакал и вызвал его на бой. Но лев даже не обратил на него внимания. Тогда шакал заявил:

- Если ты не будешь со мной драться, я пойду и расскажу всем своим друзьям, что лев меня боится!

На что лев ответил:

- Пусть лучше меня осудят за трусость шакалы, чем будут презирать за такое сражение львы.

\section{$* * *$}

Один шейх достиг высшего счастья на земле: у него было две жены. Исполненный радости он пошел на базар и купил два одинаковых золотых ожерелья, которые после счастливо проведенных часов подарил своим женам, попросив каждую не говорить об этом другой.

Но земное счастье редко бывает безоблачным. В один прекрасный день к нему явились обе жены вне себя от соперничества и ревности и накинулись на него с вопросами:

- Скажи же нам, великолепнейший из мужчин, кого из нас ты любишь больше всего?

- Мои дорогие, больше всего на свете я люблю вас, стараясь их успокоить, ответил шейх.

- Нет, нет, - протестовали жены. - Мы хотим узнать, кому из нас двоих ты даришь свою самую большую любовь?

- Мои обожаемые, зачем вы ссоритесь? Я заключил вас обеих в свое сердце. 
Но женам этого было мало.

- От нас ты так не отделаешься. А ну-ка, признавайся, кто из нас повелительница твоего сердца?

Так как шейх уже больше не мог устоять перед натиском жен, он прошептал многообещающе:

- Если вы непременно хотите это знать, я скажу вам всю правду. Ту из вас, которой я подарил золотое ожерелье, я люблю больше всего.

Обе жены взглянули друг на друга торжествующе, каждая была уверена в своей победе.

Умер старик. Но перед тем, как попасть в рай, увидел он всю свою жизнь в виде песчаного берега моря, а на берегу следы ног. Пригляделся и видит, что следы то от одной пары ног, то как будто бы два человека идут рядом. И спросил он у Бога: «Чьи следы рядом с моими?»А Бог ответил: «Это я иду рядом с тобой». Тогда старик присмотрелся получше и увидел, что в счастливые моменты жизни он шел рядом с Богом, а в трудные моменты Бог покидал его. И спросил старик Бога: «Почему ты покидал меня в трудные моменты жизни?» И ответил ему Бог: «Ты все неправильно понял, старик. Когда тебе было хорошо, я действительно шел рядом, а в трудные моменты твоей жизни я брал тебя на руки».

$* * *$

Богатый юноша влюбился в случайно встретившуюся ему на пути девушку и женился на ней. У девушки не было одной руки, и она стыдилась юноши. Бог услышал ее молитву и восстановил ей руку. 
Однажды за обедом супруги услышали голос нищего, просящего подаяние. Жена взяла два куска хлеба, хотела вынести, но муж остановил ее. Она заплакала, сочтя это за скупость, но он сказал:

- Этого мало, дай ему тарелку супа и кусок мяса.

Она взглянула на нищего и увидела, что это ее первый муж, из скупости ставший нищим. Тогда она рассказала мужу свою историю. Ее первый муж был чрезвычайно скуп. Однажды, когда его не было дома, она дала нищему курицу, в которую спрятала ценное кольцо. Вернувшись, муж очень разгневался, развелся с ней и изгнал из города, отрубив ей руку. Муж заплакал и сказал, что этим нищим был он, а кольцо дало ему богатство.

За щедрость! 


\section{Торжественные мероприятия}

\section{День рождения}

\section{Поздравление Коллеге}

Примите самые теплые поздравления по случаю Вашего Дня рождения! Ваши человеческие качества, инициативность, энергия и профессионализм заслужили высокую оценку среди коллег. Искренне рады, что знаем Вас лично и высоко ценим как доброго, чуткого и отзывчивого человека. Пусть все Ваши усилия, направленные на развитие (указать) системы получают должное понимание и поддержку.

В этот знаменательный день позвольте от всей души пожелать Вам здоровья и чтобы Удача, Успех и Вдохновение были верными спутниками во всех Ваших начинаниях!

\section{$* * *$}

Мне доставляет огромное удовольствие от всей души поздравить Вас с Днем рождения!

Ни один год нашей жизни не проходит бесследно, каждый из них дает нам очень многое: жизненный опыт и мудрость, поддержку и верность друзей и, конечно, достижения в профессиональной деятельности.

В праздничный день желаю Вам крепкого здоровья, счастья, успешного воплощения в жизнь всего задуманного, радостей от каждого прожитого дня!

Пусть Вам всегда сопутствуют большие победы, интересные впечатления и яркие эмоции, которые сделают Вашу жизнь красочнее и возвышеннее! 
Желаю Вам и Вашему уникальному коллективу уверенно и энергично идти к намеченным целям, решать самые трудные задачи и добиваться блестящих результатов!

$* * *$

Сердечно поздравляем Вас с Днем рождения!

Благодарим Вас за высокий профессионализм, самоотдачу, трудолюбие, ответственный подход к решению рабочих задач, инициативность и новаторский подход! Мы восхищаемся Вашей энергичностью, оптимизмом и активной жизненной позицией! Мы уверены, что накопленный Вами колоссальный опыт станет залогом успешной реализации еще многих проектов.

Пусть Ваш День рождения будет ярким и запоминающимся, щедрым на поздравления и внимание друзей и любимых! Желаем Вам здоровья, счастья, любви, исполнения всех желаний!

$* * *$

В замечательный, чудесный и светлый день я хочу поздравить вас с Днем рождения! Мне очень приятно отметить, что Ваши опыт, знания и профессионализм сочетаются с уникальными способностями расположить к себе людей, женским обаянием и остроумием, которые при любых, даже сложных, обстоятельствах помогают сохранять веру в успех!

Пусть жизненный баланс Ваших самых заветных желаний всегда полностью сходится с размером материальных и физических возможностей, доходы постоянно превышают расходы, любовь с каждым днем только преумножается, а счастье с каждой минутой только прибавляется! 
Как незаметно, но быстро течет необратимая река жизни в бесконечном пространстве - времени. Вот и Вас она привела к важной отметке. Настал черед остановиться на мгновение, чтобы оглядеть пройденный путь и всмотреться в будущее.

Начав работу в нашем коллективе, Вы достаточно быстро освоились со спецификой и особенностям работы и благодаря своим личным качествам - глубоким знаниям, доброжелательности, коммуникабельности, добросовестности и принципиальности - очень быстро завоевали уважение сотрудников.

Есть такая притча о том, как правильно загадывать желания:

Старый слепой одинокий нищий случайно поймал птицу счастья.

- Отпусти меня, - попросила она, - тогда я исполню любое твое желание. Но имей в виду, что желание может быть только одно.

Старик подумал и сказал:

- Я хочу увидеть, как мои внуки играют алмазами на седьмом этаже моего дворца.

Так вот, пусть в этот день исполнится одно Ваше желание, а как правильно его загадать, Вы уже знаете.

А я, в свою очередь, хочу пожелать Вам праздничного настроения, множество восхитительных событий, преданных друзей, крепкого здоровья и больших успехов в Вашей нелегкой организационной деятельности. С Днем рождения!

\section{$* * *$ \\ Сегодня наступил тот день, к которому готовятся задолго до него, сегодня Ваш День рождения!}


Есть хорошая мотивационная фраза: «Работа должна приносить человеку удовольствие!», и я в полной мере согласен с ней, потому что в нашей организации работает такой человек, как Вы, совместная работа с которым всегда удовольствие!

Несмотря на то, что наш коллектив отнюдь не маленький, все вместе и каждый в отдельности, не удивляйтесь, завидуют сегодня Вашей вечной молодости, Вашей энергии, Вашему оптимизму, Вашей способности видеть впереди перспективы и находить в себе силы их достигать, Вашему умению понимать людей, замечать в каждом достоинства, поддерживать словом и делом.

От себя лично хочу пожелать бодрости, силы, надежды, здоровья, терпения, яркой жизни, силы духа, опьянения от счастья! С Днем рождения!

Жизнь - это интересный и амбициозный проект, который подчас требует не просто личностного развития, но и настоящей трансформации, метаморфозы личности.

Вы очень успешны в реализации этого проекта. Видимо, Вам известны способы раскрытия собственных возможностей, чтобы жить, получая удовольствие от жизни и отношений с другими людьми.

Желаем Вам и в будущем относиться к жизни с позитивной, обоснованно оптимистичной точки зрения и излучать замечательное настроение!

$* * *$

Сегодня у Вас, можно сказать, юбилей. С этого момента Вы официально перестали быть молодым специалистом, ведь 30 лет 
для мужчины - это этап серьезных целей, пора устойчивого положения и высокого статуса. Это возраст свершений, когда человек сформировал свой взгляд на этот мир, на людей, определил свою нишу в обществе и расставил по местам жизненные приоритеты, и в то же время у него еще сил и энергии хоть отбавляй. К этому возрасту Вы уже многого добились: выучились, женились, поднялись по карьерной лестнице (указать). Но, надеюсь, в душе Вы сохраните свой молодой задор и активность, а будет меняться лишь количество достижений, которыми можно гордиться. Ведь когда Вы молоды, Вы уверены, что Вам все по силам, а любая задача решается на раз-два-три... Поэтому не потеряйте это ощущение беззаботной молодости!

В этот праздничный день желаю Вам новых побед, здоровья, растущей работоспособности, оптимистичного настроя на протяжении всей Вашей жизни и неиссякаемого запаса энергии, который так необходим на Вашем ответственном посту. Впереди у Вас еще множество свершений: если перефразировать известную фразу, то дерево Вы уже посадили, дом построили, а что идет следующим пунктом, и так отлично знаете. Пусть во всех делах Вам сопутствуют успех и удача, а рядом всегда будут верные друзья, понимающие коллеги и любящие близкие!

$$
* * *
$$

Среди всех прекрасных качеств нашего дорогого коллеги я хочу выделить одно - это неизменный оптимизм, с которым он идет по жизни. А знаете, как расшифровывается слово ОПТИМИЗМ?

$\mathrm{O}$ - опытный,

П - превосходный работник,

Т - трепетный, 
И - искренний,

М - мечтатель,

И - и, наконец,

3 - замечательный,

М - мужчина!

Выпьем за оптимизм этого замечательного мужчины. С Днем рождения!

\section{$* * *$}

Свой очередной День рождения Вы встречаете полная творческих сил и замыслов в процессе активного и эффективного свершения планов и идей. Вы вносите бесценный вклад в развитие системы социального обеспечения, реализацию судьбоносных для региона национальных проектов и программ, а также укрепление авторитета нашей организации как флагмана фундаментальных и инновационных научных исследований и разработок. Широта и глубина Ваших жизненных интересов не могут не вызывать восхищения. Ваша яркая биография является свидетельством Вашей активной жизненной позиции.

Мы, Ваши коллеги, с удовлетворением и гордостью воспринимаем то, что Ваша безупречная и продуктивная работа отмечена правительственными наградами.

От имени всего (указать) искренне поздравляю Вас с Днем рождения, желаю счастья, крепкого здоровья на многие годы Вам и Вашей семье!

$* * *$

От всей души поздравляю Вас с Днем рождения.

Несмотря на Ваш юный возраст, Ваш авторитет и талант по достоинству оценены на региональном уровне. Если расставить 
по значимости качества, благодаря которым Вы пользуетесь всеобщей любовью и уважением, то на первом месте будет ответственность, затем компетентность и твердость в достижении поставленных целей, способность генерировать и принимать новые идеи.

Желаю и в дальнейшем бесконечно покорять новые рубежи!

Выражаю уверенность в том, что Ваши многогранные таланты будут активно способствовать решению Ваших профессиональных задач! За время Вашей работы наша организация продвигается вперед в своем развитии, а Вы находите все большее признание как успешный руководитель одного из сложных участков государственной службы.

Пусть во всех делах и начинаниях сопутствуют удача и успех в Вашей плодотворной деятельности!

Примите искренние поздравления по случаю Вашего Дня рождения!

У всего, что нас окружает, рождено или создано, - у всего есть начало. Стартовая черта или точка отсчета, рождение идеи или плана действий, главное, что в любом случае - это движение вперед...

И не случайно мудрые говорят, что начало - половина дела. Самое сложное, как показывает жизненная практика, именно начать. Кто начинал - тот знает. Сдвинуться с места, с мертвой точки, сделать первый шаг к достижению поставленной цели... Лишь начав, можно продвинуться дальше.

Это впереди будут взлеты и падения, провалы и успехи бесценный опыт, а результат ждет только того, кто начал свой путь.

Вы даете пример не просто удачной карьеры, но настоящего и искреннего служения выбранному делу! 
Самое важное в жизни человека - достойно делать свое Дело, быть честным во всех начинаниях и поступках. Уверены, что все, знающие Вас, согласятся: Вы в полной мере отвечаете этим качествам, состоявшись как высокий профессионал, талантливый специалист своего дела, эффективный руководитель и просто достойный уважения Человек!

$* * *$

Примите самые искренние поздравления в День Вашего рождения!

Ваш День рождения - это новая точка отсчета больших дел и новых трудовых свершений, которые предстоит осуществить Вам - человеку, масштаб личности и высокие профессиональные качества которого трудно переоценить. Уверены, что Ваша неиссякаемая энергия принесет еще много пользы в нашем общем деле, приумножая и улучшая результаты.

Я восхищаюсь вашими деловыми качествами, организаторскими способностями, умением много и плодотворно работать, совмещать требовательность и обаяние. Наша организация по праву гордится такой яркой личностью и с уверенностью рассчитывает на Ваш интеллектуальный потенциал в реализации дальнейших социально значимых проектов!

Успехов, здоровья, радости и счастья! Пусть удача сопутствует во всех делах и в жизни будет множество интересных и восхитительных событий! Пусть аромат подаренных цветов и внимание любящих людей дарят приятные минуты и большое счастье в этот праздничный день!!! 


\section{Поздравление Женщине}

Искренне поздравляю Вас с Днем рождения.

C каждым годом восхищаюсь Вашей способностью с каждым годом молодеть и хорошеть. Ваш яркий темперамент с каждым Днем рождения вносит яркие ноты, добавляет «перчинки» в Ваш образ настоящей женщины-загадки. Вы всегда купаетесь в мужском внимании, но мы всегда знаем Вас как образцовую жену и маму.

Как любая женщина Вы сотканы из противоречий, и это прекрасно, ведь из женских слабостей рождаются неповторимость, возможность, сила. Между прочим, принимать свои противоречия вместо того, чтобы подавлять их, значит ценить множественность углов зрения. Кстати, как писал Пикассо: «Если бы истина была одна, невозможно было бы написать сто картин на одну тему».

Желаю Вам здоровья, солнечных дней, интересных путешествий, новых неизведанных граней жизни, семейного покоя и уюта.

\section{$* * *$}

От всей души поздравляем тебя с Днем рождения! Пусть этот день будет ярким и запоминающимся, щедрым на поздравления и внимание родных и друзей!

Всегда хорошее настроение и теплая улыбка (Имя) создают оазис спокойствия и уверенности в нашем коллективе. Мы восхищаемся твоими деловыми качествами, организаторскими способностями, умением много и плодотворно работать, совмещать требовательность и безумное обаяние.

Желаем тебе здоровья, счастья, любви, исполнения всех желаний, множества интересных и восхитительных событий! 
Пусть дети радуют тебя своими успехами! Пусть твоя жизнь будет наполнена теплом и солнечным светом независимо от прогноза погоды!

$* * *$

От всей души поздравляю Вас с Днем рождения!

Я восхищаюсь Вашими деловыми качествами, организаторскими способностями, умением много и плодотворно работать, совмещать требовательность и обаяние.

Такой красивой женщине, как Вы, можно и нужно говорить замечательные слова каждый день, а не только в День рождения.

Желаем успехов в сложной и ответственной работе, реализации всех намеченных планов. Пусть удача, успех и вдохновение будут верными спутниками во всех начинаниях, а здоровье и благополучие - в ежедневной жизни. Пусть сбудутся Ваши сокровенные желания и устремления, сохранится все хорошее, что есть в жизни, и приумножатся мгновения радости.

Пусть Вас всегда окружают уютная атмосфера в доме и на работе, маленькие радости и большие победы, интересные впечатления и яркие эмоции, которые сделают Вашу жизнь еще красочнее и насыщеннее!

Пусть аромат подаренных цветов и внимание любящих людей дарят приятные минуты и большое счастье в этот праздничный день!!!

\section{$* * *$}

Любимая подруга, поздравляю тебя с Днем рождения!

30 лет - это только старт к новым победам и успехам!

Женщины переменчивы, мы порой сами с трудом можем определить, чего хотим и к чему стремимся. А уж со счастьем вообще сплошная путаница. Иногда мы только спустя какое-то 36 
время можем осознать, что пару часов (недель, лет) назад уже испытывали его, свое настоящее счастье. Счастье - понятие сложное, порой неуловимое.

Желаю тебе, чтобы ощущение счастья всегда было с тобой, каждую минуту жизни, чтобы каждый день приносил простые маленькие радости. Как женщина женщине желаю тебе быть окруженной заботой, нежностью и любовью! Желаю тебе получать удовольствие от работы и параллельно с этим полноценно отдыхать!

Деньги же способны добавить нам душевного благополучия, если будут вложены нами... в новый жизненный опыт, новые впечатления, путешествия. Поэтому пусть каждый год твоей жизни пополняет капитал воспоминаний, которые и спустя время заряжают нас энергией, позволяя вновь переживать яркие моменты жизни!

Примите искренние поздравления по случаю Вашего Дня рождения!

Маргарет Тэтчер, Индира Ганди, Ангела Меркель, Кондолиза Райс, Валентина Матвиенко, Ирина Хакамада - великие успешные женщины-руководители, за которыми закрепилась слава «железной леди», умеющей четко отстаивать свои позиции, решать сложные задачи, несмотря ни на какие преграды.

Конечно, можно назвать еще сотни людей, которые преодолевая трудности и преграды, реализовали свой потенциал, ведь преодолевая обстоятельства, мы укрепляем уверенность в своих силах. Как там говорят: «То, что не убивает нас, делает нас сильнее!», а ведь тот, кто идет вперед вопреки трудностям, может 
увлечь за собой окружающих. Не случайно слово «начальник» происходит от слова «начало», а эта должность Вас давно и везде преследует. Начальник - это тот, кто ответственен за продвижение вперед, кто обладает качествами, необходимыми для достижения успеха.

Женская интуиция, душевная щедрость, лояльность, необыкновенно широкий кругозор и доброжелательное отношение к подчиненным... Все эти качества, которые Вы неизменно олицетворяете собой, снискали заслуженное уважение!

В этот праздничный для Вас день примите искренние пожелания доброго здоровья и успехов в претворении планов и замыслов! Пусть каждый новый день приносит только удачу, заряжает энергией и позитивным настроением! И пусть Вас всегда окружает атмосфера добра, искренности и взаимопонимания, а поддержка и любовь близких придает силы для плодотворной работы!

\section{$* * *$}

Примите самые искренние и сердечные поздравления с Днем рождения! Поздравлять красивую женщину с Днем рождения всегда особенно приятно.

Этот знаменательный день Вы встречаете в расцвете сил, на рубеже новых свершений, с проектами будущих работ.

Мы гордимся Вашими профессиональными успехами и значительным вкладом в развитие страны.

Условия существования человечества на пороге третьего тысячелетия требуют переход к новой стратегии развития общества на основе знаний и высокоэффективных технологий. Поэтому формирование перспективной системы социального развития, соответствующей этой цели, сегодня одна из важнейших 38 
проблем государства. Мы осознаем бесценность Вашего вклада в развитие важнейшей области экономики.

Мы убеждены, что Ваш организаторский талант, высокий авторитет, большой опыт государственного и общественного деятеля и в дальнейшем будут эффективно использованы для реализации избранной стратегии социально-экономических преобразований в стране.

Желаем Вам крепкого здоровья, успехов в Вашей многогранной деятельности, мира, счастья и благополучия Вам, Вашим родным и близким.

Я уверен, что все мы единодушны в том мнении, что именинница является идеалом красоты и женственности, олицетворяя собой гармоничное сочетание карьерного роста, красоты, обаяния, света и тепла семейного очага. Красота человека - это синтез красоты внешней и красоты семейных и профессиональных отношений.

Ваши личные качества и поступки заряжены квантами жизненной энергии, которой вы щедро делитесь с окружающими. Вы поддерживаете любые нововведения, тем самым помогая поддерживать креатив в работе (указать).

Ваша мудрость и женская интуиция помогают сглаживать острые ситуации во взаимоотношениях, которые неизбежно возникают в любом коллективе. Все, к чему Вы прикасаетесь, отличается неповторимостью стиля.

Вашу жизнь можно сравнить с насыщенной и яркой экспозицией. Мы уверены, что новый год Вашей жизни принесет Вам только положительные результаты и достижения. 
Пусть День Вашего рождения будет еще одним фрагментом калейдоскопа счастливых событий!

***

Примите самые искренние поздравления по случаю Вашего Дня рождения!

Проработав вместе с Вами не один год, можно уверенно сказать, что трудиться рядом с таким профессионалом, как Вы, большая удача!

Мы все прекрасно знаем, насколько непросто работать в такой крупной многофункциональной структуре, как (указать).

Сформулированный Авраамом Линкольном принцип «наилучший способ предсказать свое будущее - это создать его» как нельзя лучше характеризует Вашу жизненную позицию. Вы не надеетесь на капризную фортуну, а действуете, трудитесь и достигаете успеха в любом деле, за какие бы не взялись. Вы отличаетесь особым аналитическим складом ума, отсюда и практичность, рациональность и здравомыслие.

По гороскопу Вы - (указать), и это о многом говорит. Рожденные (дата), несомненно, глубокие личности - многогранные, творческие люди с неуемным фонтаном энергии, с сильным волевым характером, трудолюбивые и целеустремленные.

Являясь примером в работе даже для многих мужчин-руководителей, Вы при таком объеме работы и грузе ответственности умудряетесь сохранять оптимизм и женское обаяние! С Вами приятно работать, на Вас можно положиться в любых вопросах, которые требуют компетентности.

Уверены, что накопленный опыт работы, помноженный на Вашу энергию, принципиальность, усердие и женскую интуицию, позволит Вам и в дальнейшем добиваться значительных 40 
результатов по многим направлениям! Крепкого Вам здоровья, счастья, семейного благополучия и удачи во всем!

Мне доставляет огромное удовольствие от всей души поздравить Вас с Днем рождения!

Вспомним, сколько великих поэтов и мыслителей воспевали безграничную душевную щедрость и любовь, нежность, красоту и верность женщины, слагали прекрасные стихи и поэмы женщинам, на чьих хрупких плечах держатся мир и согласие в семье, благополучие и взаимопонимание в обществе. Эти замечательные образы, в первую очередь яркие и неповторимые образы женской красоты и преданности, воспетые великими поэтами, живут сегодня в наших современницах, одной из который являетесь Вы!

Благодаря своим знаниям и таланту, своей целеустремленности сегодня женщины плодотворно трудятся в самых разных сферах, на поприще государственного и общественного управления. Самоотдача, трудолюбие и ответственный подход к решению любого вопроса, энергия и оптимизм помогают Вам на столь ответственной должности решать сложнейшие задачи. Инновационный взгляд на управление, умение не только следовать времени, но и быть на шаг впереди него позволяют Вам глубоко понимать суть проблем и эффективно их решать.

Примите искренние и сердечные поздравления с Днем рождения! Как руководителю желаю Вам мудрости и терпения, поддержки и понимания коллег и подчиненных! Пусть накопленный профессиональный опыт станет основой для дальнейших свершений! А как прекрасной женщине - больше улыбок, солнечных дней и хорошего настроения! 
Примите наши искренние поздравления с Днем рождения!

Каков идеал женщины? Вот вопрос, вечно актуальный и постоянно волнующий. В каждую эпоху люди хотят открыть что-то новое в глубинах женского мирового начала. Современный идеал женщины включает в себя много аспектов. Во все времена восхищение вызывали женщины, занимающиеся социально важным делом - люди науки и государства, которые используют знания и опыт во имя людей.

Пусть Ваш День рождения будет ярким и запоминающимся, щедрым на поздравления и внимание друзей и любимых!

Желаем Вам здоровья, счастья, любви, исполнения всех желаний!

Примите искренние поздравления со знаменательной датой Днем Вашего рождения!

В Вашей жизни «язык цифр» имеет большое значение. Однако, зная Вас не только как профессионала своего дела, но и как Женщину с большой буквы, понимаешь, что цифры над Вами совершенно не властны!

Такие необыкновенные качества, как женственность, обаяние, открытость, которые Вы неизменно олицетворяете собой и которые так радуют нас, мужчин, делают Вас поистине украшением нашего (указать)!

Множество добрых слов хочется сказать Вам в этот прекрасный весенний день как заслуженному работнику (указать). Вы вносите весомый вклад в создание устойчивой, сбалансированной (указать) в регионе. 
Поздравляя Вас с Днем рождения, хочется пожелать Вам (пусть это и звучит тривиально) прежде всего здоровья, потому что жизнь требует от нас много сил и энергии! И пусть Вам всегда сопутствует все самое чистое, светлое, доброе, а главное исполнения всех надежд и желаний, а также дальнейших профессиональных побед и истинного удовлетворения от любимой работы!

\section{$* * *$}

Примите искренние поздравления по случаю Вашего Дня рождения!

Нам очень приятно отметить, что Ваши опыт, знания и профессионализм сочетаются с уникальными способностями расположить к себе людей, женским обаянием и остроумием, которые при любых, даже сложных, обстоятельствах помогают сохранять веру в успех!

Всем, кто работает с Вами, отлично известно, что Вы всегда подкрепляете бескомпромиссность и ответственность позитивным отношением к работе, окружающим людям и, вообще, к жизни.

Как говорили древние мыслители: «Если Вы вкладываете в свое дело еще и душу - Вам не будет равных!» Поэтому в этот праздничный день хочется пожелать Вам всегда оставаться верной своему делу, не отклоняться от намеченного пути. Пусть Ваша любимая работа приносит только радость и удовлетворение!

Желаем Вам успехов в достижении поставленных целей, новых профессиональных побед, оптимизма, реализации задуманных планов и, конечно, доброго здоровья, семейного счастья и благополучия! 


\section{Поздравление Руководителю}

В нашей суматошной жизни редко удается встретить человека, времени общения с которым никогда не бывает много. Это происходит и потому, что человек этот умен и интеллигентен, и потому, что он последователен и принципиален, а прежде всего потому, что он честен и порядочен. Французские просветители говорили, что «честность есть истинный аристократизм нашего времени».

Вы относитесь к тем людям, которые достойно несут в себе эту честность уже в наше время.

Вы один из тех, кто стоял у истоков формирования (указывается по ситуациии). Принимая участие в создании целого ряда стратегических программ, Вы смогли привнести в них самые эффективные экономические модели.

Мы уважаем Вас как самого ЛУЧШЕГО и самого авторитетного наставника! И нам будет очень полезно не только перенять Ваш опыт и знания в экономической сфере, но и поучиться у Вас энергичности и душевной молодости.

От всей души мы поздравляем Вас с Днем рождения! Желаем Вам результата, превосходящего все Ваши самые-самыесамые смелые ожидания. Будьте ярчайшим эпицентром Жизни, пусть Ваша энергия бьет ключом и все получается как по волшебству. Пусть встречаются лучшие люди, происходят лучшие события, претворяются в жизнь лучшие надежды! Пусть погода будет словно в сказке - самая солнечная, самая теплая, самая яркая! И удача каждый день будет с Вами, чем бы Вы ни занимались, где бы Вы ни были, что бы ни делали... Эта неизменная спутница пусть помогает Вам и приносит неожиданное, 
долгожданное и только приятное в Вашу жизнь! А еще творческой активности, вдохновения на грани фола, Музу - оригинальную, а Гения - трудолюбивого!

\section{$* * *$}

Примите самые искренние и самые теплые слова поздравлений с Днем рождения!

Менялись поколения, эпохи, но неизменным оставалось высокое качество и профессионализм Вашей работы. Без преувеличения можно сказать, что Вы, будучи человеком, проделавшим непростой пусть профессионального становления, стали авторитетом как среди своих коллег, так и среди руководящего состава, которые ценят Ваш колоссальный управленческий опыт, умение эффективно решать сложные и многоплановые задачи!

Понимаем, как сложно при таком объеме работы и при таком грузе ответственности сохранять бодрость духа, оптимизм и женское обаяние, но Вам удивительным образом это удается!

В этот прекрасный весенний день примите самые искренние пожелания доброго здоровья и успехов в претворении планов и замыслов. Пусть каждый новый день приносит только удачу, заряжает энергией и позитивным солнечным настроением! И пусть Вас всегда окружает атмосфера добра, гармонии и взаимопонимания, душевный комфорт и равновесие и в профессиональной сфере, и в личной жизни.

$* * *$

Примите искренние поздравления в День Вашего рождения!

Мы знаем Вас как талантливого руководителя, уважаем за мастерство в работе и преданность однажды избранному делу. Благодаря Вашему высокому профессионализму и творческому 
подходу к управлению нам удается достигнуть значительных успехов во всех начинаниях.

Наша организация успешно развивается и подтверждает право занимать ведущие позиции в сфере (указать): ... лет работы в условиях стремительно меняющейся российской экономики по насыщенности, динамизму, масштабам, темпам роста сопоставимы с вековой историей развития. Вашему стилю работы характерны открытость новым веяниям, стремление к внедрению современных технологий.

Желаем крепкого здоровья, дальнейшего процветания, благополучия и удачи!

Желаем Вам и Вашему уникальному коллективу уверенно и энергично идти к намеченным целям, решать самые трудные задачи и добиваться блестящих результатов!

Сердечно поздравляем с Днем рождения!

Ваша карьера, безусловно, является результатом Ваших деловых качеств, профессионализма и умения правильно выстраивать взаимоотношения с любым партнером. Вас характеризуют цельность натуры, широта взглядов и острота мысли. Будучи мудрым политиком и талантливым управленцем, Вы являетесь ярким примером человека, жизнь которого достойна подражания.

Масштабность и объем работы, проделанной под Вашим руководством, вызывают уважение. Мы убеждены, что профессионализм, жизненный опыт, высокая ответственность, авторитет, чуткое отношение к людям будут и впредь помогать Вам в Вашем созидательном и социально значимом труде. 
Желаем безграничного жизненного оптимизма и упорства в достижении поставленных целей, но - главное - удачи и большого количества единомышленников, без которых Вам было бы трудно осуществлять все Ваши планы и начинания.

Желаем крепкого здоровья, долгих лет жизни, всего самого доброго!

Пусть не иссякнет Ваш заслуженный авторитет и уважение тех людей, которые Вам доверяют и идут за Вами.

$* * *$

Карьера руководителя в любой сфере предполагает максимальную отдачу и поглощенность работой, несмотря на это, очевидно, что Вам этот бешеный ритм приносит радость и удовлетворение.

Ваша компетентность и энергичность позволяют решать проблемы любого уровня. Мы очень ценим то, что можем рассчитывать на Вашу помощь, ведь именно стратегия взаимопомощи обеспечивает наибольшую эффективность работы коллектива. Ученые доказали, что успеха в работе позволяет добиться не только коэффициент интеллекта IQ, а также и EQ - коэффициент эмоциональности, связанный с образностью мышления и гибкостью поведения. Очевидно, что оба эти коэффициента у Вас максимальны.

Искренне поздравляем Вас с Днем рождения!

Желаем каждый день испытывать чувство свободы и внутреннего обновления, полноты и гармонии существования рядом с другими людьми! 
Ваша многогранная деятельность, основанная на профессионализме и порядочности, чутком отношении к окружающим, всегда приводила к успешному решению всех поставленных задач! Поэтому вполне закономерно, что на сегодняшний день Вы являетесь заслуженным деятелем науки и руководителем высочайшего ранга.

Примите сердечные поздравления в День Вашего рождения, а также самые добрые пожелания крепкого здоровья, удач и неизменного успеха, как в профессиональной деятельности, так и в личных делах!

$* * *$

Этот День рождения Вы встречаете в расцвете своих сил и талантов! Не страшась трудностей, Вы сделали головокружительную карьеру, став незаменимым специалистом. Без преувеличения хочется отметить, что Вы, будучи человеком, проделавшим непростой путь профессионального становления, стали авторитетом среди коллег и руководства!

Еще раз поздравляю Вас с праздником и отмечу, что Ваша неутомимая энергия, несгибаемый характер, неиссякаемое общение, организаторский талант и богатый опыт руководителя снискали заслуженное уважение.

Желаю Вам успехов в достижении поставленных целей, новых профессиональных побед, оптимизма, реализации всех задуманных планов, доброго здоровья, семейного счастья и благополучия!

Пусть Ваше любимое дело приносит только радость и удовлетворение! 


\section{$* * *$}

От всей души поздравляем Вас с Днем рождения!

Быть руководителем - искусство и ежедневная сложная работа, которая Вам удается очень успешно и легко! Всегда хорошее настроение и теплая улыбка создают оазис спокойствия и уверенности в самых непростых ситуациях. Ваш богатый опыт и профессиональные качества позволяют успешно руководить, сплотив вокруг себя талантливый и опытный коллектив.

Такой женщине, как Вы, можно и нужно говорить замечательные слова каждый день, а не только в День рождения.

Желаем успехов в сложной и ответственной работе, реализации всех намеченных планов. Пусть удача, успех и вдохновение будут верными спутниками во всех начинаниях, а здоровье и благополучие - в ежедневной жизни. Настойчивости и терпения в решении каждодневных задач! Пусть сбудутся ваши сокровенные желания и устремления, сохранится все хорошее, что есть в жизни, и преумножатся мгновения радости.

Пусть Вас всегда окружает уютная атмосфера в доме и на работе, маленькие радости и большие победы, интересные впечатления и яркие эмоции, которые сделают Вашу жизнь еще красочнее и насыщеннее!

Нам очень приятно, что Вашу очередную годовщину мы встречаем в качестве членов Вашей команды, потому что это особая честь и особая ответственность - быть рядом с Вами и помогать Вам в реализации огромного количества планов, проектов, решений, имеющих президентскую планку качества. 
Благодаря Вам наше предприятие заслужило звание современной и перспективной организации, открытой для свежих идей и новейших разработок.

Для множества других регионов наша организация являет собой пример талантливого и умелого менеджмента, грамотного и высокопрофессионального управленческого подхода, искусного воплощения перспективных проектов во всех сферах.

Я восхищаюсь Вашим стремлением развиваться и совершенствоваться, максимально эффективно использовать заложенный потенциал, реализовать все возможности.

Я хочу пожелать Вам добрых, надежных друзей на этом пути, высокопрофессиональных и инициативных сотрудников.

Я хочу пожелать Вам терпения, мудрости и стойкости, которые так необходимы человеку и политику, который не боится ставить перед собой грандиозные цели, который мечтает о счастливом будущем своей страны и отдает этой мечте все силы своей души.

Искренне желаю Вам крепкого здоровья, стабильности и процветания, счастья и благополучия!

Мы видим, что ни один год Вашей жизни не проходит бесследно, каждый из них дает Вам очень многое: жизненный опыт и мудрость, поддержку и верность друзей, и, конечно, достижения в профессиональной деятельности.

Всегда все с уважением относятся к деловым людям, к их неисчерпаемой энергии, работоспособности, творческой жилке, смелости, умению рисковать и преодолевать все трудности на 
своем пути. Все эти качества, несомненно, относятся и к Вам, у Вас еще и оптимистический взгляд в будущее.

Вот в связи с этим, так сказать, оптимистическим взглядом вспоминается один случай, который мог бы быть и в реальной жизни.

Обувная фирма послала двух торговых агентов в Центральную Африку для проведения маркетингового исследования.

Через несколько дней пришли две телеграммы.

«Дела плохи, - сообщил первый агент, - тут все ходят босиком».

«Нас ждут большие прибыли, - пишет второй, - тут все ходят босиком».

Вы, точно как второй агент из рассказа, не боитесь трудностей и во всем находите оптимистичное продолжение.

Благодаря Вам сегодня наша фирма заслужила звание не то чтобы лидера, а именно современной и перспективной организации, открытой для свежих идей и новейших разработок.

Для множества других регионов наша компания, как бы то ни говори, являет собой пример талантливого менеджмента, грамотного и высокопрофессионального управленческого подхода, искусного воплощения перспективных проектов во всех сферах. В связи с этим вспоминается старый анекдот, только поймите его именно в политическом смысле.

У одного человека был кот. Кот как кот, самый обыкновенный. И как и положено котам, каждый март месяц кот проводил неизвестно где и возвращался домой достаточно потрепанный, но довольный.

Человеку этому надоели похождения кота, и он проделал над ним известную операцию. Но вот приходит март, и кот опять 
пропадает из дома и возвращается лишь через месяц - опять довольный! Хозяин у него спрашивает:

- Но сейчас-то, сейчас что ты там делал?

- Я руководил! - гордо ответил кот.

Подводя итог всему сказанному, мы хотели бы Вам пожелать также оптимистично идти по жизни к своим целям, энергии и упорства, которые порой необходимы для достижения своей мечты и, конечно же, крепкого здоровья и благополучия!

\section{$* * *$}

Примите самые теплые слова поздравлений с Вашим замечательным праздником, Вашей «личной датой» - Днем рождения!

В нашей работе актуальна формула: «То, что не убивает нас - делает нас сильнее!» Преодолевая трудности, мы одновременно и приобретаем опыт поведения в той или иной ситуации, и укрепляем уверенность в своих силах! Нередко происходит как в старом анекдоте: «Шаг вперед является следствием хорошего пинка под зад!» Всякое начало трудно - и с этой истиной не поспоришь! Не случайно слово «начальник» происходит от слова «начало».

Уверены, что все, знающие Вас, согласятся: Вы в полной мере отвечаете качествам эффективного руководителя, способного нацеливать людей на результат, добиваться его, складывая воедино общие усилия.

Ко всему вышесказанному, хочется пожелать Вам в этот день новых профессиональных побед и истинного удовлетворения от выбранного дела. Кроме того, в Вашем новом увлечении бодибилдингом желаем добиваться поставленных перед собой целей на пути к обретению идеального телосложения, о котором Вы мечтаете. Никогда не останавливаться на достигнутом... 52 
Начать никогда не поздно, важно - довести начатое до конца... Значит, ВПЕРЕД!!!

\section{$* * *$}

Ваша непростая работа - быть из числа руководителей одной из самых авторитетных и востребованных структур требует выдающихся организаторских способностей, глубоких профессиональных знаний и огромных ресурсов духовной и физической энергии. Все эти качества Вам в полной мере присущи.

Мудрость и сила, здравый расчет и жизненный опыт характеризуют Ваш стиль работы и помогают успешно воплощать в жизнь самые смелые проекты.

Ваши деловые и личные качества - умение ладить с людьми, способность воплощать результат Вашей работы на практике, талант чутко улавливать перемены, воспринимать новое и претворять это новое в жизнь и работу - снискали заслуженное уважение среди коллег и руководителей!

Примите искренние поздравления по случаю Вашего Дня рождения! Желаем Вам осуществления новых масштабных планов, неиссякаемой энергии, настойчивости в реализации поставленных целей и, конечно, крепкого здоровья и благополучия Вам и Вашим близким!

Уверен, что новый год Вашей жизни принесет Вам только положительные результаты и достижения! 


\section{$* * *$}

Примите самые искренние поздравления по случаю Вашего Дня рождения!

Проработав вместе с Вами не один год, можно уверенно сказать, что трудиться рядом с таким профессионалом, как Вы, большая удача!

Не страшась трудностей, в расцвете своих сил, жизненной энергии и талантов Вы сделали блестящую карьеру, став руководителем столь важного ... одной из самых авторитетных и востребованных структур.

Являясь примером в работе даже для многих мужчин-руководителей, Вы при таком объеме работы и грузе ответственности умудряетесь сохранять оптимизм и женское обаяние! С Вами приятно работать, на Вас можно положиться в любых вопросах, которые требуют компетентности и надежности, и при этом не бояться за результат!

Можно смело утверждать: управление людьми - это целая наука, требующая выдающихся организаторских способностей, глубоких профессиональных знаний и навыков, таланта ладить с самыми разными людьми, мудрости и профессионального чутья. Все эти качества Вам в полной мере присущи.

Уверены, что накопленный опыт работы, помноженный на Вашу энергию, принципиальность, усердие и женскую интуицию, позволит Вам и в дальнейшем добиваться значительных результатов по многим направлениям! Крепкого Вам здоровья, счастья, семейного благополучия и удачи во всем! 


\section{Именные}

Уважаемая Надежда!

Примите искренние поздравления по случаю Вашего Дня рождения!

Не можем не отметить, что на действия и характер человека накладывает отпечаток его имя. В имени Надежда огромный заряд энергии, терпеливости и целеустремленности. По своей звуковой энергетике Ваше имя обладает достаточной твердостью и основательностью. Носить такое имя - большая честь и ответственность, и Вы его с достоинством оправдываете!

Вы, Надежда, - человек с внутренним стержнем... Обычно такими бывают мужчины, но Вы, умея преодолевать трудности и обладая колоссальной силой воли, стали авторитетом среди коллег и руководства!

Женская интуиция, душевная щедрость, эмоциональность, необыкновенно широкий кругозор... Все эти качества, которые Вы неизменно олицетворяете собой, снискали заслуженное уважение!

В этот праздничный для Вас день примите искренние пожелания доброго здоровья и успехов в претворении планов и замыслов! Пусть каждый новый день приносит только удачу, заряжает энергией и позитивным настроением! И пусть Вас всегда окружает атмосфера добра, искренности и взаимопонимания, а поддержка и любовь близких придает силы для плодотворной работы!

\section{$* * *$}

Хочу предложить тост за нашу именинницу, чье красивое имя очень ей подходит.

Я долго пытался выяснить значение имени, но, видимо, оно так же загадочно, как и его обладательница. Некоторые источники 
утверждают, что Эльмира - в переводе с испанского - «принцесса», другие источники - что это имя арабское и означает «порядочная», «добросовестная».

Когда-то рыжеволосых женщин называли «дочерьми солнца». Действительно, рыжие волосы наделяют обладательницу особыми чарами, энергетикой, тайной и даже придают образу что-то мистическое. Женщины с рыжими волосами выделяются из толпы, привлекают внимание. Именно поэтому Эльмира - настоящая принцесса. По мнению психологов, девушек с натуральным рыжим цветом волос природа одарила большей жизненной энергией, настойчивостью, целеустремленностью. Очень часто это люди с яркой харизмой. Это, безусловно, относится и к Эльмире. Мы восхищаемся ее деловыми качествами, организаторскими способностями, умением много и плодотворно работать, совмещать требовательность и обаяние.

От имени всего ... и от себя лично желаю Эльмире успехов, здоровья, радости и счастья. Пусть удача сопутствует во всех делах и в жизни будет множество интересных и восхитительных событий! Пусть аромат подаренных цветов и внимание любящих людей дарят приятные минуты и большое счастье в этот праздничный день!!!

\section{$* * *$}

У нашего именинника очень красивое имя, в переводе с арабского оно означает «посланник», «желанный».

Специалисты по толкованию имен утверждают, что люди, носящие имя «Марат», прагматичны, благоразумны, осторожны, пунктуальны и методичны, очень трудолюбивы и настойчивы в достижении своих целей и задумок. Они проявляют инициативу, в любом деле быстро находят рациональное зерно, часто стре- 
мятся попробовать свои силы в чем-то новом. Я думаю, что наш именинник полностью соответствует этому описанию. Именно эти качества позволили ему добиться успехов в бизнесе.

Также Марат обладает бесценным сокровищем - крепкой и любящей семьей. Семья в наше время - не роскошь: в сложном, меняющемся мире мы острее, чем раньше, нуждаемся в этой опоре. Все большее значение в современной семье приобретает функция психологической поддержки. Марату эта поддержка обеспечена, ведь у него с женой подрастают сын и дочка.

Таким образом, Марат - абсолютно счастливый человек. Считают, что успех приходит к тем, кто рано встает. Нет, успех приходит к тем, кто встает в хорошем настроении.

Так давайте же выпьем за то, чтобы ты, Марат, всегда был в хорошем расположении духа, что будет лучшим доказательством мудрости!

Дорогие друзья! Хочу поднять тост за Сверкающую (Солнечную), Волшебную, Единственную, Талантливую, Лучезарную, Артистичную, Неотразимую, Ангельски красивую даму! Надеюсь, по первым буквам эпитетов Вы догадались, что речь идет о Светлане. Светлана, желаю Вам исполнения всех заветных желаний, душевного комфорта и как можно больше поводов для радости и веселья!

$$
* * *
$$

Уважаемая Любовь!

Ваше имя пришло в Россию вместе с православием и является славянским переводом аналогичного греческого имени, 
означающего чувство любви. Это имя вызывает лучшие чувства по отношению к женщине, носящей это имя.

Что касается энергетики данного имени, стоит заметить, что какой бы притягательный и обаятельный смысл не закладывался в имя Любовь, нетрудно заметить, что звучит оно довольно твердо и страстно.

Я уверен, все согласятся со мной, что к имениннице можно применить такие эпитеты, как умная и энергичная, деловая и талантливая.

Ведь каждый день мы вместе с Вами решаем текущие проблемы, а общее дело и интересы, как известно, лучше всего сближают людей. Нам приходится ежедневно решать множество задач, и мы были бы плохими профессионалами, если бы в рабочей обстановке не ценили в своих коллегах их личные качества.

Всем известно, что успехи нашей организации опираются на Ваш высокий профессионализм, на Ваши таланты и способности, на сложившиеся в возглавляемом Вами (указать) традиции и восприимчивость к новому. Пусть этот юбилей будет лишь ступенькой в Вашей карьере.

Мы верим, что новый год Вашей жизни принесет обновление и множество сюрпризов. Пусть жизнь Ваша будет яркой, щедрой и полной радости!

Искренне желаем Вам процветания, крепкого здоровья и счастья!

$* * *$

Примите самые теплые слова поздравлений в этот замечательный день! 
30 лет - великолепный возраст, расцвет красоты, здоровья и самореализации. Это прекрасная пора силы, стремлений и свершения желаний.

Вы занимаетесь очень сложным и ответственным делом в одном из самых авторитетных структурных подразделений. Успешное выполнение задач, поставленных перед (указать)... ключевым (указать) нашей организации, - зависит прежде всего от каждодневного кропотливого труда, профессионализма, чувства ответственности и незаурядного таланта его сотрудников.

Пока нас окружают такие профессионалы, как Вы - энтузиасты, способные принимать решения, творческие натуры, которых не пугают перемены, нас ждет успех!

Давно обзавелась крыльями фраза мультяшного капитала Врунгеля: «Как вы лодку назовете, так она и поплывет!» Не можем не отметить, что на действия и характер человека накладывает отпечаток его имя. Имя - это некий опознавательный шифр, который несет определенный запас энергии.

В имени Диана огромный заряд энергии и целеустремленности. По своей звуковой энергетике Ваше имя обладает достаточной твердостью и основательностью. Впрочем, благодаря своему характеру Дианы способны добиться большого успеха! Носить такое имя - большая честь и ответственность, и Вы его с достоинством оправдываете!

В этот замечательный день хотим пожелать Вам неустанно покорять новые рубежи, сохранять свежесть ощущений и мировосприятия, вечную молодость и любовь к жизни!

Наслаждайтесь Жизнью, кружите головы, будоражьте сознания и будьте всегда любимы! 


\section{Поздравление Мужчине}

Поздравляю тебя с Днем рождения!

Ты очень сильная личность, целеустремленный и энергичный человек! Я восхищаюсь твоим умением не опускать руки в трудные жизненные ситуации. Преодолев трудности, ты возрождаешься, как Феникс, и оказываешься победителем. Мудрецы утверждают, что все, что не убивает нас, делает сильнее.

Я уверен, что все черные полосы в твоей жизни позади, и теперь ты успешно реализуешь свои грандиозные планы.

32 года - это не возраст для мужчины, ты уже многого добился и перед тобой открываются большие перспективы.

Желаю тебе здоровья, семейного благополучия, пусть твои заветные желания сбудутся и наступивший новый год жизни будет ярким, успешным и счастливым!

***

Уважаемый именинник и дорогие гости!

Я знаю (Имя) уже давно, так сказать, с институтской скамьи, и в связи с этим вспомнил анекдот.

Корабль терпит крушение, и пассажиры попадают на остров, где живет людоед. Первого он съедает на завтрак, второго на обед, третьего - на полдник... Четвертого отпускает восвояси, предоставив ему шлюпку и запас еды. «Почему?» - удивляются все. «Да я с ним вместе в институте учился» - отвечает он. Шутки шутками, но недаром говорят, что самое полезное в высшем образовании - это люди, с которыми вместе сидел на институтской скамье.

Хорошо иметь влиятельных друзей, зачастую какой-то сложный рабочий вопрос можно решить простым телефонным звонком. Конечно, поддерживать дружеские связи необходимо 60 
не только руководствуясь возможной выгодой. Но, признаюсь, приятно осознавать, что твои друзья занимают столь высокие посты в столь юном возрасте, ведь по возрасту наш именинник далеко не аксакал.

В чем же секрет успеха моего друга? Он очень прост, и, думаю, мой друг не будет против, если я поделюсь им со всеми присутствующими.

Работая на разных участках деятельности, трудных и ответственных, он руководствуется принципом: «Трудное - это то, что может быть сделано немедленно, невозможное - то, что потребует немного больше времени».

Как видим, все очень просто. Также хотел бы добавить, что всегда восхищался работоспособностью (Имя), его стремлением познавать новое, осваивать новые сферы деятельности. Также (Имя) просто прекрасный человек, очень надежный друг и профессионал своего дела.

Думаю, мне пора завершать свой тост, который, кажется, затянулся из-за лирических отступлений. Я готовил свою речь заранее, но, к сожалению, забыл заготовку дома. Что было дальше в моей бумажке, не помню, но в конце, помню, предлагалось ВЫПить.

\section{$* * *$}

В День Вашего рождения желаем реализации грандиозных планов, заслуженных побед и стабильности!

Хочется пожелать Вам не только безграничного жизненного оптимизма и упорства в достижении поставленных целей, но главное - удачи и большого количества единомышленников, без которого Вам было бы трудно осуществлять все Ваши планы и начинания. 
Пусть не иссякнет Ваш заслуженный авторитет и уважение тех людей, которые Вам доверяют и идут за Вами.

Пусть возраст означает лишь проценты тех рубежей, что предстоит достичь!

Мы желаем Вам ежедневных счастливых открытий, которые делают жизнь яркой и гармоничной, мудрости, зоркости, терпения и последовательности, здоровья, бодрости духа и хорошего настроения!

$* * *$

Спешим поздравить Вас с Днем рождения!

Множество добрых слов хочется сказать Вам в этот день как человеку, имеющему незаурядный талант, выдающиеся организаторские способности, глубокие профессиональные знания и огромные ресурсы физической и умственной энергии! Вы даете пример не просто удачной карьеры, но и настоящего и искреннего служения выбранному делу!

Уверены, что все, знающие Вас, согласятся: Вы в полной мере состоялись как высокий профессионал, эффективный руководитель, талантливый спортсмен и просто достойный уважения Человек!

Ко всему вышесказанному хочется пожелать Вам и в профессиональной, и в спортивной, и в личной жизни точных пасов, красивых голов, справедливых судей и неоспоримых побед!

$$
* * *
$$

Хочу предложить тост за самого желанного гостя на этом мероприятии - именинника - и рассказать небольшой анекдот. 
«Что такое ананас?» - спросили у одного кавказца. Тот не растерялся: «Яблоки знаешь? Лимоны знаешь? Хурму знаешь? Арбуз знаешь? Так ананас на это совсем не похож».

Позвольте мне спросить: «Кто такой бизнесмен?» И самому же ответить: «Трус знаешь? Пентюх знаешь? Лентяй знаешь? Глупый знаешь? Так это совсем наоборот!» Давайте выпьем за именинника! Чтобы всем его начинаниям сопутствовала удача!

В каждом человеке природа всходит либо злаками, либо сорной травой. Так давайте же выпьем за то, чтобы своевременно поливать первое и истреблять второе! За этот прекрасный сад, который вырастил в себе именинник!

$* * *$

Поздравляю тебя с Днем рождения! Ты - эталон настоящего мужчины: профессиональный пловец, футболист, мастер игры по настольному теннису. Я уверен, что все мужчины искренне завидуют тебе, ведь на тебя трудно равняться.

Также ты надежный коллега, на которого всегда можно положиться в сложных рабочих моментах. Ведь каждый день мы вместе решаем текущие проблемы, а общее дело лучше всего сближает людей. Нам приходится ежедневно решать множество задач, и мы были бы плохими профессионалами, если в рабочей обстановке не ценили бы в своих коллегах их личные качества.

Желаю тебе найти способы полностью раскрыть свои возможности, чтобы жить, получая удовольствие от жизни и отношений с другими людьми! На Кавказе есть поверье, что время, которое ты проводишь за столом с друзьями, не засчитывается в 
возраст. Поэтому пусть празднование твоего Дня рождения не ограничится сегодняшним днем. Здоровья, карьерного роста и семейного счастья!

\section{Поздравление Родственникам}

Идеал зрелости, по мнению психологов, состоит из 3 составляющих.

Во-первых, это опыт, который помогает справиться с тем, с чем ты не сталкивался раньше. Во-вторых, ответственность, когда ты отвечаешь не только за свои поступки, но и за других. И, наконец, тождество самому себе.

Необходим синтез этих трех измерений: опыта как отношения к миру, ответственности как отношения к другим и аутентичности как отношения к самому себе. Целью человека является своего рода высшее согласие, примирение с собой, с другими и с миром.

В День Вашего рождения примите искренние поздравления с тем, что Вы идеала достигли!

Желаю крепкого здоровья, стабильности во всех жизненных сферах и счастья!

Дорогая дочка, ты всегда говорила, что хочешь, чтобы у тебя был такой характер, как у меня, твоего отца. Хочу тебе признаться, что у меня скверный характер, и мне требуется проявлять немало силы воли, чтобы обуздать его. Я считаю, что твой добрый, мягкий, женственный характер - это твой «капитал», с которым тебе будет легче идти по жизни. Ибо, как говорится: «Видимая мягкость достоинства скрывает тысячи возможностей!» 
Я хочу пожелать тебе воспользоваться этими возможностями и добиться своей мечты! За тебя, доченька!

Дорогая сестра, я поздравляю тебя с прекрасным днем, когда все с восхищением смотрят на тебя. Ты купаешься в лучах счастья и веселья. Искрится шампанское: в твою честь произносят тосты друзья и подруги. Пусть это волшебное состояние праздника будет с тобой всегда. Здоровья тебе, успехов и исполнения желаний! С Днем рождения!

$* * *$

«Привычки отца, и плохие, и хорошие, превращаются в пороки детей», - сказал Ключевский и был прав. Я всегда старался стать лучше, понимая, что чем лучше буду я, тем лучше будет мой сын. Надеюсь, мне это в какой-то степени удалось.

Я хочу поздравить тебя, сын, с Днем рождения. И в этот прекрасный день, такой радостный для нас, твоих родителей, пожелать тебе быть упорным в достижении цели, при неудачах не раскисать, а становиться еще более собранным, чтобы с новой энергией штурмовать вершину своей мечты.

$* * *$

60 лет - этот возраст говорит об опыте, авторитете и безграничном уважении к его обладателю.

Это большая награда иметь таких мудрых и любящих родителей, как Вы. Своими успехами мы обязаны маме и папе, Вашему воспитанию и любви.

Вы всегда были примером для нас. Один мудрый человек сказал: «Каждое слово матери или отца для меня - золотая монета». Пусть сыпется на нас дождь золотых монет Ваших 
советов. Мы хотим, чтобы ты и мама еще долгие годы радовались нашим успехам.

Пусть день рождения будет ярким и запоминающимся, щедрым на поздравления и внимание друзей и любимых! Желаем, чтобы каждый день приносил радость. Желаем крепкого здоровья и исполнения всех желаний!

\section{$* * *$}

Сегодня в адрес юбиляра было сказано много добрых слов, и это, безусловно, приятно, так как нет дороже подарка, чем теплые поздравления, исходящие от души. Этими поздравлениями наш юбиляр охарактеризован как мудрый руководитель, ответственный деловой партнер, надежный друг.

Возраст юбиляра говорит об опыте, авторитете и безграничном уважении к его обладателю. 60-летний юбилей - это значимая дата на жизненном пути, когда многое достигнуто, а накопленный опыт, мудрость, доверие людей становятся основой для новых свершений.

Я со своей стороны хотел бы рассказать о юбиляре как о любимом папе, заботливом деде и уважаемом свекре.

Дорогой папа! Мы всегда восхищаемся твоим энтузиазмом, искренностью и оптимизмом. Нас вдохновляет твое жизнелюбие и способность открывать в себе новые таланты. Я думаю, твой секрет в том, что для тебя каждая юбилейная дата - активный опыт развития, открывающий уникальные внутренние богатства личности. Ведь кроме хронологического времени ты открыл время, которое ничего не имеет общего с движением часовых стрелок. Это любовь семьи, поддержка друзей, интересные мысли. В целом, это доказательство того, что увлекательное путешествие по жизни продолжается. 
Прими от нас самые теплые и искренние поздравления с юбилеем! В этот день желаем тебе, чтобы лучшие мгновения Вашей жизни были еще впереди, чтобы каждый день приносил радость и удовлетворение. От всей души желаем тебе крепкого здоровья, долголетия, счастья и благополучия! Мы уверены, что сегодняшний изумительный день - лишь рубеж, после которого тебя ждет еще много торжественных дат.

Предлагаю поднять бокалы за здоровье юбиляра!

$* * *$

Дорогой папа! Сегодня мы все собрались здесь, чтобы поздравить тебя с Днем рождения. 60 лет - это очень красивая и достойная дата. Лично я очень люблю такие небольшие семейные торжества, когда вся семья может собраться за праздничным столом и пообщаться.

Недавно я прочитал советы психолога, которые называются «Ключи от будущего». Специалисты утверждают, что следуя этим советам можно и в возрасте аксакала ощущать себя молодым. Вот эти советы: свести к минимуму или исключить курение и алкоголь, иметь чувство юмора, нормальный вес, счастливый брак, физическую активность, высокий уровень образования.

Что-то мне подсказывает, что ты тоже читал эту статью. Ты прекрасно выглядишь, бодр, энергичен, у тебя прекрасная семья и любимая работа. Твой позитив, идущий изнутри, невозможно не заметить. Ты всегда был и есть пример для меня: в выборе жизненного пути, семейной жизни, интересах. Я уверен, что твои внуки тоже будут гордиться своим дедом.

В этот праздничный день хотим пожелать тебе здоровья, долголетия и лишь радостных событий впереди! 
Один известный человек сказал: «Вы не перестанете быть ребенком, пока у Вас есть мама».

Этот день - самый счастливый и прекрасный, потому что в этот день ты появилась на свет.

Кстати, есть такой любопытный факт: у большинства гениальных людей были замечательные матери, и, безусловно, все мои успехи - это твоя заслуга. Ты всю жизнь трудилась на благо семьи, передавала мне свои знания и мудрость, учила быть добрым и справедливым, никогда не опускать руки и идти к своей цели, поддерживала меня во всех начинаниях. Я никогда не устану благодарить тебя за это. И как говорил немецкий писатель Бертольд Ауэрбах: «Что бы ни делал человек, его дела, даже самые выдающиеся, ничего не стоят, если он не выполняет своего долга перед родителями!»

Одна древняя мудрость гласит: что ты сам сделаешь для родителей своих, того же ожидай и себе от детей. И надеюсь, глядя на то, как мы стараемся окружить тебя заботой и ответным теплом, твои внуки так же воспитают и своих детей.

Дорогая, любимая мама, ты для всех нас - источник света, ты приносишь в нашу жизнь столько радости и надежды! В твой юбилей хочу пожелать тебе, чтобы твое сердце - неиссякаемое сосредоточение любви для нашей семьи - было всегда наполнено радостью, а улыбка - самая искренняя и добрая - согревала душу. Пусть твое здоровье будет крепче самой прочной стали на земле, годы жизни длиннее самой длинной нити, а солнце над твоей головой светит так ярко, как и ты для меня. От всей души поздравляю! 


\section{$* * *$}

Когда-то ты подарила мне этот мир! Ты познавала его вместе со мной, мы вместе развивались и взрослели. Ты радовалась всем успехам, которые мы переживали вместе, и огорчалась тем неудачам, которые порой подстерегали. Поэтому твой юбилей так же важен и радостен для меня.

В мире нет ничего прекраснее, ничего самоотверженнее, ничего жертвенней, чем любовь матери. Это чувство нежно, словно первый подснежник весной, и чутко, как любимая детская игрушка. Для материнской любви не существует преград, ведь она забирает на себя любые печали, смело отводит беды своей ласковой рукой - есть ли в жизни большее счастье? О материнской любви можно говорить бесконечно, и завершить свой тост я хочу словами великого татарского поэта Мусы Джалиля:

«Мы будем вечно прославлять

Ту женщину, чье имя - мать!»

Любимая мама! В этот чудесный день я поздравляю тебя с юбилеем и сделаю все, чтобы твои глаза всегда светились счастьем, а на губах играла улыбка. Желаю всегда утопать в заботе окружающих, здоровья, долголетия, вечной молодости и красоты!

\section{В стихах}

Спасибо Вам за умопомраченье

От лицезренья Вашей красоты,

За нежности счастливые мгновенья,

За наши мысли, грезы и мечты. 
Так будьте ж счастливы и радуйте собою,

Не прекращая ни на миг цвести,

Удачи Вам, весеннего настроя,

Поклонников, улыбок и любви!

Любви взаимной и непроходящей,

Здоровья, окрыленности мечтой...

И восхищайте нас, коллег, почаще

Своим изяществом и красотой!

\section{$* * *$}

Нет! Женщина не виновата,

Когда приходит эта дата -

Тут календарь всему виной.

А Вы, всем датам вопреки,

Все так же молоды душой,

Стройны, изящны и легки.

Мы Вам желать не будем много,

Достоинств Ваших всех не счесть...

Так оставайтесь, ради Бога,

Всегда такой, какая есть!

А возраст - это не беда,

Переживем все юбилеи!

Ведь в жизни главное всегда,

Чтобы душою не старели.

$* * *$

Ты такой чудесный человек,

И поэтому твой День рождения 
Праздником становится для всех!

Так прими сегодня поздравления,

Пожелания радости, тепла,

Чтоб всегда счастливой жизнь была!

$* * *$

С Днем рожденья тебя поздравляю,

Веселись в этот день, не грусти,

От души тебе счастья желаю

И огромной счастливой любви!

Пусть мечты твои будут крылаты

И безоблачны светлые дни,

И от этой сверкающей даты

Старт возьмут все успехи твои!

$* * *$

Пусть палитра жизни будет светлой,

Радостной от сочных, ярких красок!

Пусть удача станет очень щедрой,

Красной розой расцветает счастье!

Много радостных событий,

Ярких, как в калейдоскопе,

Пусть предсказывают звезды,

Обещают гороскопы!

Пусть загадки и тайны Вселенной

Восхищают, влекут, интригуют!

Пусть живется легко, вдохновенно,

А родные почаще балуют!

Пусть фантазии и грезы

В жизни воплощаются! 
Пусть приятные моменты

Чаще приключаются!

Пусть праздник украшает солнце

И теплый ветерок резвится,

Букет цветов благоухает,

Мелодий хоровод кружится!

Пусть счастье в воздухе витает

И дарит красоту и нежность!

Пусть никогда не покидают

Здоровье, силы, шарм и свежесть!

Пусть пожелания будут сердечными

И исполняются без промедления,

Жизнь станет яркой, насыщенной встречами,

Чаще приходит пора вдохновения!

Пусть перемены приносят успехов всплеск,

Дарят эмоции и приключения,

Радость в глазах отражает волшебный блеск,

Будут счастливыми дни и мгновения!

Пусть светятся в твоих глазах

Надежда и участие!

Купайся в солнечных лучах,

Плыви на волнах счастья!

Пусть согревают сердце вновь

Мечта и вдохновение,

В душе всегда живет любовь

И радует общение! 
Пусть неизведанное счастье

Зовет и манит в свои дали!

Желаю, чтобы те, кто рядом,

Любили, верили и ждали!

Будь, как весна, очаровательной

И жизнерадостной всегда!

Пусть в небе чаще появляется

Твоя счастливая звезда!

Пусть в душе всегда царят

Счастье и гармония!

Пусть звезда любви горит,

Льется чувств симфония!

$* * *$

Сегодня я хочу поднять бокал

За то, чтобы все, что ты ни пожелала,

Сбывалось без промедлений и проблем,

И чтобы жизнь одаривала всем:

Здоровьем, счастьем, дружбой и любовью,

Чтобы всегда друзья были с тобою,

И чтобы год весь после Дня рожденья

Был прожит без тревог и сожалений.

\section{Юбилей}

В природе существуют деревья, которые по-своему уникальны. При любых условиях жизни, в дождь, в мороз, в засуху, они всегда красивые и нарядные. Так и среди людей, есть такие, в жизни которых все было: и бури, и стужа, жара и ураганы. 
Но они остались красивыми и обаятельными. Таким человеком является и наша юбилярша.

Вы сохраняете преемственность фундаментальных ориентиров развития нашей организации, Ваша деятельность является примером для нас.

В нашем мире женщине приходится быть сильной, возлагать на свои хрупкие плечи множество забот, особенно на таком высоком посту. Но настоящая сила не в том, чтобы руководить подчиненными, настоящая сила - в женственности.

В день юбилея я хочу пожелать Вам всегда оставаться такой, как сейчас - настоящей женщиной, красивой и грациозной, чуточку таинственной! Вы всегда добры и приветливы, аккуратны и внимательны, серьезны и рассудительны, умеете и сказать верное слово, и сделать любую работы всем на загляденье! От всей души желаю Вам крепкого здоровья, долголетия, счастья и благополучия! Пусть Вас всегда окружает уютная атмосфера в доме, маленькие радости и большие победы, интересные впечатления и яркие эмоции, которые сделают Вашу жизнь еще красочнее и насыщеннее!

\section{$* * *$}

Позвольте поздравить вас с юбилеем!

Психолог - относительно новая профессия для нашего общества, но она уже стала необходимой в современных условиях. Иногда достаточно одного лишь понимающего взгляда, одного слова, чтобы человек начал жить полноценно, а не просто существовать. И это возможно с помощью грамотной профессиональной работы психолога, ведь быть хорошим психологом значит быть мудрецом и ученым в одном лице. Вы успешно начали внедрять систему работы с руководителями в форме 74 
деловых игр и тренингов, развивая их потенциал, раскрывая их профессиональные возможности. Искренне желаю Вам удачи в Вашем нелегком труде. Вы должны всегда находить то, что не видно нам, открывать завесы тайны психологии сотрудников нашей организации, как в несмешном анекдоте:

Психолог спрашивает клиента:

- Вы курите?

- Нет.

- Пьете?

- Нет.

Психолог говорит: «Не надо так усмехаться, я все равно чтонибудь найду!»

Тем более, как вы знаете, человек, который в процессе тренинга помогает обучающемуся достичь некой жизненной или профессиональной цели, называется «коуч». Думаю, и юбиляршу с уверенностью можно назвать коучем нашей организации. И Вы должны как коуч ловить золотых рыбок, наших сотрудников, и превращать их в акул системы (указать).

В этот юбилей желаю Вам дальнейших успехов в обучении и профессиональном развитии наших коллег, а кроме того, чтобы все плохое осталось позади. Пусть впереди ожидают лишь радостные мгновения, солнце освещает Ваш путь, а удача ведет Вас за руку к новым победам и достижениям. Здоровья, любви, везения на долгие годы! 
Примите сердечные поздравления с Днем рождения, Вашей юбилейной датой!

Что можно пожелать мужчине, который к 35-летию добился жизненного и материального успеха, у которого прекрасная семья и двое малышей? Это трудный вопрос, однако, как известно, в нашей организации нет слова «невозможно».

Карьера руководителя в любой сфере предполагает максимальную отдачу и поглощенность работой, несмотря на это, очевидно, что Вам этот бешеный ритм приносит радость и удовлетворение.

В День Вашего рождения желаю повышения эффективности управления на Вашем сложном участке работы, квалифицированных и ответственных сотрудников, а также всех удачных свершений и больших достижений в будущем!

Пусть каждый новый день приносит чувство свободы и внутреннего обновления, полноты и гармонии существования рядом с другими людьми!

Искренне желаем крепкого здоровья, счастья. Пусть среди будней суеты будут праздники, пусть Вас окружают только преданные коллеги и друзья! Пусть энергия Ваша и стремление доводить все до идеала никогда не закончатся!

\section{$* * *$}

Примите сердечные поздравления с Днем рождения, Вашей юбилейной датой!

В своих руках Вы крепко держите самый важный участок работы - (указать). Только благодаря Вам наше предприятие может спокойно работать. На Вашем примере можно еще раз 
убедиться в том, что Вы сочетаете профессионализм, целеустремленность и рассудительность, успешный опыт работы.

\section{$* * *$}

Не буду озвучивать юбилейную дату, ведь Вы для всего коллектива и особенно для Вашего родного (указать) всегда остаетесь молодой и энергичной, всем на зависть! Так что, с вечным 18-летием, (Имя)!

Пусть Ваша жизнь будет наполнена пониманием и поддержкой единомышленников, теплом домашнего очага, любовью родных и близких! Уверен, что Ваша энергия, знания и опыт позволят и в дальнейшем успешно решать задачи по развитию (название).

От имени (указать) и от себя лично горячо и сердечно поздравляю Вас с юбилейной датой!

Юбилей - та граница жизни, на которой принято оглядываться назад, оценивать достигнутое и ставить перед собой новые цели. Как сказал известный персидский поэт: «В знании величие и краса, знание дороже, чем клад жемчужин. Время любой уничтожит клад, мудрый и знающий вечно нужен».

На Вашем примере можно еще раз убедиться в том, что Вы сочетаете профессионализм, целеустремленность и рассудительность, успешный опыт работы на самых ответственных участках. Благодарим Вас за самоотдачу, трудолюбие, ответственный подход к решению любого вопроса, добросовестную работу на благо (указать)!

Желаем Вам крепкого здоровья, счастья Вам и Вашим близким, благополучия и стабильности! Пусть Ваша жизнь будет наполнена пониманием и поддержкой единомышленников, теплом домашнего очага, любовью родных и близких! Мы уверены, 
что Ваша энергия, знания и опыт позволят и в дальнейшем успешно решать задачи по развитию нашей организации.

\section{$* * *$}

Я рад присутствовать на этой встрече, посвященной Вашему юбилею.

Я хотел бы пожелать Вам успешно реализовывать инновационные проекты, не опасаясь не соответствовать шаблонам и стандартам, что во многих случаях, безусловно, более легкий путь. Сейчас Вы успешно внедряете различные проекты, постоянно следите за обновлениями бухгалтерских программ, даже вносите свои предложения по их усовершенствованию...

Как-то раз разработчика спросили:

- Для чего вообще нужны бухгалтерские программы?

- Как для чего? Для снижения безработицы, конечно! Там, где раньше сидел один бухгалтер, теперь сидят еще оператор, программист, пять наладчиков и начальник (указать) вычислительной техники.

Я уверен, что Вы блестяще справляетесь с возложенными на Вас обязанностями. Ведь Вы знаете данный участок работы, так сказать, изнутри, пройдя путь от специалиста и руководителя районного масштаба до масштаба центрального офиса. В таком вертикальном построении карьеры есть неоспоримые преимущества: знание всех деталей деятельности, деловая репутация, имидж, хорошо налаженные рабочие связи.

Итак, искренне желаю успехов во всех начинаниях, смелых и творческих взвешенных решений! Пусть работа принесет радость и профессиональное удовлетворение! А теперь предоставлю слово остальным присутствующим здесь коллегам, уверен, 
что каждый из них желает сказать в Ваш адрес несколько теплых слов.

Без сомнения, Вы - самый важный работник в нашей организации. Именно от Вас зависит его работоспособность и взаимоотношения с контролирующими органами. И весь наш коллектив очень рад, что сегодня с Вашего лица не сходит очаровательная улыбка. Вы не просто главный бухгалтер, а человек с большой буквы, мастер своего дела. Благодаря Вашему нелегкому труду, знаниям и организованности наша фирма имеет отличную репутацию, а сотрудники всегда получают заработную плату вовремя.

От души благодарю Вас за приглашение на Ваш праздник. Сегодня Вы показали себя не только профессионалом своего дела, но и хлебосольной хозяйкой, устроившей такой прекрасный стол. Уверен, что как бухгалтер вы точно рассчитали количество угощений и напитков, чтобы хватило на всех Ваших гостей! Так что принимайте заслуженные комплименты, поздравления и повеселитесь от души!

Все знают, что математики пьют до бесконечности, химики до окосения, медики - до потери пульса. В последнее время многих интересует вопрос: как пьют бухгалтера? Так вот, установлено: бухгалтера пьют до потери баланса! И сегодня у всех здесь присутствующих есть шанс проверить это утверждение.

В день Вашего юбилея искренне желаю вам, чтобы дебет всегда сходился с кредитом, неумолимо бегущие минуты отсчитывали только приятные моменты в Вашей жизни, деньги в кошельке росли в геометрической прогрессии, а в душе не было места для грусти и невзгод! Еще раз поздравляю! 
Примите самые теплые и искренние поздравления с юбилеем!

60 лет - изумительный юбилей, это молодость, задор и мудрость зрелости! Этот возраст говорит об опыте, авторитете и безграничном уважении к его обладателю. 60-летний юбилей это значимая дата на жизненном пути, когда многое достигнуто, а накопленный опыт, мудрость, доверие людей становятся основой для новых свершений.

Мы всегда восхищаемся Вашим энтузиазмом, вниманием к деталям, искренностью и умением вдохновлять людей. На своем высоком посту Вы сохраняете преемственность фундаментальных ориентиров развития нашей организации, Ваша деятельность является примером взаимодействия органов (название) в целях скорейшего решения самых насущных государственных задач. Мы искренне благодарны Вам за консультации, помощь в расстановке приоритетов, актуальные рекомендации, смелый, нетривиальный подход к решению возникающих проблем.

В этот юбилейный день желаем Вам процветания, развития стратегической линии карьерного роста, новых научных идей, дискуссий и поиска решений практических задач, стоящих перед Вами!

Желаем Вам, чтобы лучшие мгновения Вашей жизни были еще впереди, чтобы каждый день приносил радость и удовлетворение, а Ваша работа открывалась новыми интересными гранями. Ведь жизнь - это не только те дни, что прожиты, но и те, что запомнились.

От всей души желаем Вам крепкого здоровья, долголетия, счастья и благополучия! 
Мне, как руководителю, конечно, приятно, что у меня работает столь одаренная особа. Но скажу немножко по другому.

Сегодняшний юбилей (будем называть его юбилеем, нам нужна помпезность, мы ее даже любим) - это не только твой праздник. Это праздник твоих родителей, мужа, детей, и, конечно же, твоих любимых сотрудников, у которые есть такая дочь, жена, мама, коллега, как ты!

Коллектив, как говорится, любит сильных и отважных, стойких и мудрых. И он не только тебя любит, но и гордится тобой, как и мы.

Как говорил Брежнев или Ельцин: «Позволь выразить благодарность за совместную плодотворную работу в решении важнейшей задачи».

Твой профессионализм, опыт, талант служат залогом решения вопросов развития. Желаем тебе крепкого здоровья, долгих лет жизни, дальнейшей политической карьеры, благополучия и семейного счастья!

$* * *$

От всей души поздравляю Вас с юбилеем!

Чехов отметил, что в человеке все должно быть прекрасно: и лицо, и душа, и мысли. Вы являетесь примером, наиболее точно отражающим это суждение. В Вас прекрасно все!

Многие годы Вы посвящаете свою работу населению нашей страны, ее благополучию, и это большая честь - работать в одной сфере с таким выдающимся профессионалом.

Человек, обладающий столькими благородными качествами, не мог не воспитать своих детей такими же, любящими свое 
дело, самоотверженными профессионалами и просто хорошими людьми.

Красивая женщина не может иметь недостатков, а такая женщина, как Вы, и вовсе идеальна!

В этот праздничный день искренне желаю Вам, чтобы Ваша жизнь была полна радостных моментов, чтобы работа приносила удовольствие, а дома ждали любовь и забота близких.

Никто не поспорит, что виновница торжества стала на один год красивее, привлекательнее и умнее! Говорят, кстати, что сорок лет - это зрелость молодости, а пятьдесят - это молодость зрелости. Так что вся зрелость еще впереди...

Я пью за мудрость нашей дорогой юбилярши, которая с поднятой головой идет по жизни, оставляя за собой добрые дела.

Прими искренние пожелания: успехов в работе, крепкого здоровья, личного счастья, благополучия.

Прекрасно сказал Шопенгауэр: «Подобно тому, как факелы и фейерверки бледнеют и делаются невидимыми при свете солнца, так и ум, даже гения, а равно и красота, блекнут, затмеваются сердечной добротой».

Я хочу поднять бокал и выпить за сердечную доброту нашей юбилярши, которая согревает всех нас подобно солнцу.

$* * *$

На вопрос, кого можно считать счастливым, Сократ ответил: «Того, у кого честный образ мыслей и острый ум». Исходя из сказанного, наш юбиляр счастлив, потому что обладает достоинствами, которые указал великий философ. Наш юбиляр всегда поступает по справедливости, у него прекрасный ум гения. Как не 
выпить за такого достойного человека и не порадоваться его счастью. За нашего доброго юбиляра!

$$
* * *
$$

Китайская мудрость говорит величайшую правду о том, что мудрый человек представляется в трех изменяющихся видах: когда на него смотришь издалека, он кажется важным и суровым; когда приблизишься к нему, то видишь, что он нежен и приветлив; когда услышишь его слова - он представляется строгим и жестким. Уважаемый ..., наш замечательный директор, безусловно, мудрый человек. Издали он кажется суровым, а приди к нему со своими проблемами, он встретит приветливо и поможет, но и потребовать может. Выпьем за здоровье нашего уважаемого юбиляра!

Молодость - это состояние бесконечного ожидания и ощущения того, что все возможно. Вы, уважаемый (Имя), сохранили крепкое здоровье и молодость души. Мы видим, что у Вас высокий уровень метаболизма, интенсивная работа нейронов, постоянные выбросы адреналина в кровь, ну и, разумеется, ускоренный цикл Кребса.

Это напомнило мне одну историю.

На чествовании Уинстона Черчилля по случаю его 80-летия один фоторепортер обратился нему с вопросом:

- Я надеюсь, господин Черчилль, что мне будет позволено и в день столетия сфотографировать Вас?

- В таком случае, - ответил Черчилль, - вам придется двадцать лет тщательно заботиться о своем здоровье. 
И я хочу поднять бокал за то, чтобы все присутствующие здесь гости брали пример с Вас и спустя 50 лет смогли поздравить Вас со столетним юбилеем!

Но суть не в годах, а в делах - их-то и надо считать. Несомненно, Вашу жизнь, уважаемый (Имя), наполняют замечательные дела, и множество прекрасных свершений Вы еще можете сделать. У Вас для этого есть все: талант, здоровье, уважение и любовь родных и близких.

Есть хорошее выражение, отлично подходящее к Вам: «Мужчина в 50 лет более опасен, чем в любом другом возрасте, поскольку имеет ценнейший опыт и, зачастую, состояние». Окружающие испытывают к Вам глубокое уважение именно за огромный жизненный опыт, который Вы в себе аккумулируете. Этот опыт невозможно переоценить, особенно если он щедро приправлен свойственным Вам бесценным жизнелюбием. От всей души желаю Вам никогда не терять Ваш поразительный оптимизм и использовать его в сочетании с Вашим опытом для исполнения всех Ваших планов!

$* * *$

Я хочу рассказать всем присутствующим, и в первую очередь нашему дорогому юбиляру одну историю, известную с давних времен, но не утратившую своей актуальности и сегодня.

Стояло вдоль дороги старое засохшее дерево. Как-то раз поздним вечером проходил мимо него преступник. В темноте он смог разглядеть под деревом силуэт полицейского. Испугавшись, преступник убежал и начал вести законопослушный образ жизни. Влюбленный юноша, проходивший мимо этого дерева, ускорял свой шаг, так как издалека смог разглядеть образ своей возлюбленной. Когда же мимо дерева проходила молодая мать с 84 
ребенком, малыш плакал, потому что это дерево представилось страшным чудовищем. А истина заключалась лишь в том, что это простое старое дерево, однако каждый из нас способен увидеть в нем то, чем заняты его мысли, что является смыслом его жизни.

Сегодня я хочу поднять бокал за нашего именинника, достигшего 60-летнего юбилея. Наш юбиляр прошел довольно долгий жизненный путь, но у него впереди еще много целей и планов, которые обязательно необходимо достичь. Я искренне желаю, чтобы в Вашей жизни, (Имя), встречались только счастливые и радостные «силуэты».

\section{$* * *$}

Хочу напомнить, как в далеком детстве мы задували на праздничном торте столько свечей, сколько лет нам исполнялось. Со временем торт становился все больше - ведь и количество свечей росло. Я хочу пожелать Вам, (Имя), прожить столько лет, сколько свечей поместится на самом большом в мире торте, который испекли китайские кондитеры для Книги рекордов Гиннесса: его длина составляет 2,5 километра!

\section{$* * *$}

Для огромного большинства людей День рождения - это трудное время: мы подводим итоги, думаем о том, на что потратили еще один подаренный жизнью год, - всегда найдется чему удивиться и кого поблагодарить.

Слова «успех» и «успеть» - однокоренные, но успеть означает прийти вовремя, а не как можно быстрее. А это «вовремя» У всех разное, и каждый сам решает, на что и как тратить то единственное, чем мы на самом деле владеем, - свое время. Вы 
как человек, умеющий оптимально диверсифицировать временные ресурсы, успеваете все делать вовремя.

Вы многого достигли в плане карьеры. Мы хорошо знаем, что престиж и значение (указать) далеко не всегда определяются его размерами и характером деятельности организации. Вы выполняете чрезвычайно важную задачу в общей социально значимой миссии.

Поскольку мы с Вами коллеги, хотелось бы отметить Ваш профессионализм, способность работать в команде плодотворно, эффективно и целенаправленно.

Желаем будущих достижений и побед на благо нашего общего дела! Пусть мои искренние поздравления и наилучшие пожелания принесут Вам счастье, удачу и радость! С Днем рождения!

Один китайский философ говорил: «Мечта - это не то, что уже существует, но и не то, чего не может быть. Это как на земле - дороги нет, а пройдут люди и проложат дорогу. От всей души желаю Вам, уважаемый (Имя), обязательно проложить свою неповторимую дорогу - дорогу своей мечты! А для этого обязательно оставайтесь таким же, как и сейчас: непревзойденным профессионалом и неисправимым оптимистом! С юбилеем! 


\section{Свадьба}

Дорогие молодожены!

Если бы в свое время родители жениха не встретились и не полюбили друг друга, то на месте жениха сидел бы сейчас другой молодой человек, а если бы родители невесты много лет назад не познакомились друг с другом, то сегодня у нас не было бы такой прекрасной невесты. Давайте же вместе с вами поблагодарим родителей наших молодых за то, что они родили, вырастили и воспитали таких замечательных детей.

Дорогие родители наших молодых, сегодня ваши дети вступают в новую жизнь, и мы надеемся, что они сумеют построить дружную и крепкую семью. И этот праздник в первую очередь ваш праздник! За вас, родители!!!

Дорогие гости! Сегодня между семьями жениха и невесты образовалась новая родственная связь. Разделенное горе - половина горя, разделенная радость - удвоенная радость. Любая невзгода ощущается меньше, если она падает не на одного, а на многих, а радость становится больше.

Дружба и любовь - самые прекрасные чувства в человеческой жизни. Пусть ваша любовь будет такой же долгой, как ваша жизнь! Пусть у вас будут здоровые и жизнерадостные дети, и будьте верной опорой вашим родителям.

Вы начинаете строить свой дом, свой семейный очаг. Для себя, своих будущих детей, своих родных и близких. Мы верим, что у вас получится настоящий дворец - светлый, солнечный, уютный и для многочисленных и желанных гостей.

Все знают, что реальная жизнь состоит из множества жизненных ситуаций. Жизнь - это череда светлых и пасмурных дней. 
Так пусть повседневные пустяки не портят главного в вашей жизни - семейного счастья и радости.

Мне хотелось бы от всего сердца пожелать молодоженам, чтобы их жизнь была такой же радостной и веселой, как эта свадьба. Но свадьба потому и весела, что виновники торжества дарят остальным радость и веселье и сами радуются. Вот этот принцип отражения - любите и будете любимы - я хочу рекомендовать как важный жизненный принцип.

\section{$* * *$}

У одного мудреца была дочь.

К ней пришли свататься двое: богатый и бедный.

Мудрец сказал богатому:

- Я не отдам за тебя свою дочь, - и выдал ее за бедняка.

Когда его спросили, почему он так поступил, он ответил:

- Богач глуп, и я уверен, что он обеднеет. Бедняк же умен, и я предвижу, что он достигнет счастья и благополучия.

Если бы сегодня этот мудрец был с нами, он поднял бы чашу за нашего, безусловно, умного жениха. Он стал моим преемником на посту начальника. И я рад, что могу доверить результат моего труда (Имя).

Желаю, чтобы и в дальнейшем благодаря твоему уму твоя карьера складывалась также удачно, и ваша новая ячейка общества стала образцом благополучия!

\section{$* * *$}

В Древней Греции была богиня Ника, богиня победы в сражениях и состязаниях.

Она изображалась в виде женщины с крыльями, в венке и с пальмовой ветвью в руках - символом первенства. 
(Имя) стал одним из самых молодых и спортивных руководителей, причем стал моим преемником на посту (указать). Он всегда участвует во всех мероприятиях нашей организации. Теперь ему понадобится удача не только в спорте, но и в работе на ответственном посту, чтобы уверено привести (Название) к первому месту Лидера.

Желаю, чтобы невеста, как богиня Ника, приносила мужу удачу, победу и первенство, а через него всему нашему рабочему коллективу!

\section{$* * *$}

Молодая девушка, ехавшая на машине, сбила молодого человека, который ехал на мотоцикле. Удар оказался несильным. Юноша поднялся и обратился к прохожему:

- Вы бы не согласились быть моим свидетелем?

- Не знаю, что и сказать! - отвечает прохожий. - Вообще-то, я вам не советовал бы после такого короткого знакомства жениться!

Нам известно, что жених с невестой знакомы друг с другом несколько дольше, кроме того, и работают вместе. Любовь окрыляет, влюбленный человек чувствует себя счастливым, раньше приходит на работу, чтобы увидеть предмет своей страсти, и не спешит уйти домой. Также у коллег масса общих тем для разговоров, можно обо всем рассказать своей половинке, не боясь, что тебя не поймут. Нет необходимости ждать встречи или телефонного звонка, и каждый обеденный перерыв можно превратить в романтическое свидание. А теперь наши жених и невеста могут быть неразлучны ни на работе, ни дома. За молодых! Будьте неразлучны и счастливы всю жизнь! 
$* * *$

В компании одного гостя расспрашивают:

- Скажите, почему вы так поздно женились?

- Видите ли, прежде чем решиться на этот серьезный шаг, я хотел иметь надежный и постоянный доход.

- И теперь он у вас есть?

- Да. Я теперь регулярно получаю... пенсию!

Наш жених придерживался, судя по всему, тех же принципов: прежде всего создал крепкую материальную базу, а потом решился жениться. Слава Богу, он сумел это сделать в молодом возрасте.

Прошу поднять бокалы за молодого преуспевающего жениха.

$* * *$

«Жена и дети учат человечности; холостяки же мрачны и суровы», - считал английский философ и мыслитель Фрэнсис Бэкон. Сегодня одним холостяком стало меньше. Я поднимаю тост за новую семью, за двух любящих людей, которые нашли друг друга, и пусть в их семье поскорее зазвучит детский смех! Что, кстати, совпадает с призывом нашего президента улучшить демографическую ситуацию в стране.

$* * *$

Если бы я был Президентом Российской Федерации, то от лица всего нашего Государства Российского и от себя лично поздравил бы вас с бракосочетанием такими словами: «Сегодня вы вступили в законный брак, создали еще одну ячейку в нашем обществе. Сохраните ваши сердца такими же горячими на долгие годы, сберегите ваш союз в таком же первозданном виде, как сейчас. Сейчас вы молодая пара, но пройдет немного времени и у вас появится новый член семьи. Воспитайте его в традициях 
нашего великого Государства Российского. Отнеситесь столь же серьезно к вашему браку, как я отнесся к этому поздравительному письму. Ни на миг не переставайте любить друг друга, не забывайте своих родителей. Живите долго и счастливо. С наилучшими пожеланиями, ваш Президент Российской Федерации».

\section{$* * *$}

«Не смотреть друг на друга, но смотреть в одном направлении - вот что значит любить!» - сказал замечательный писатель Антуан Сент-Экзюпери. В этот торжественный день молодые смотрят друг на друга, а мы смотрим на них и радуемся вместе с ними их счастью. Но я хочу выпить за то, чтобы они научились смотреть в одном направлении, только тогда они станут настоящей семьей, в которой будут царить мир и понимание. Совет вам и любовь!

\section{$* * *$}

Дорогие молодожены, дорогие гости!

Как друг жениха я, конечно же, с сожалением констатирую печальный факт расставания с ним. Но, с другой стороны, я счастлив, что он нашел свою вторую половинку. Если счастлив мой друг, счастлив и я. Народная мудрость гласит, что первое богатство в жизни - это здоровье, а второе - жена. Я вижу, что избранница моего брата - прекрасная девушка.

Сегодня, в этот радостный и памятный для нас день, в адрес молодоженов прозвучало множество пожеланий, как серьезных, так и юмористических, а самое главное - искренних. Если все они сбудутся, в Вашу семейную жизнь никогда не закрадутся ни зависть, ни ревность, ни ссоры, ни злоба, а будут царить мир, согласие, доверие и любовь. 
«Ни один человек не способен понять, что такое настоящая любовь, пока не проживет в браке четверть века», - считал всем известный писатель Марк Твен. Через 25 лет совместной жизни, как известно, супруги справляют Серебряную свадьбу. Но мне это число кажется незначительным, поэтому я предлагаю выпить за то, чтобы молодые в любви и согласии прожили полвека и тогда на их Золотой свадьбе мы, глядя на них, если и не поймем, что же такое настоящая любовь, то уж точно увидим ее собственными глазами.

\section{$* * *$}

Дорогие молодожены!

Я желаю Вам быть неразлучными и счастливыми всю жизнь! Пусть Ваша жизнь будет такой же радостной и веселой, как эта свадьба. Пусть в Вашем доме будет всегда солнечная погода. Пусть у Вас будут здоровые и умные дети. Желаю, чтобы все Ваши планы реализовались, а желания сбылись.

Говорят, чтобы дожить до бриллиантовой свадьбы, надо иметь золотой характер жены и железную выдержку мужа. Предлагаю тост за чудесный сплав!

$$
* * *
$$

\section{Обещание свидетеля}

Во-первых, обещаю невесте, что с сегодняшнего дня сезон охоты на невест и ловлю русалок для жениха закрыт навсегда!

Соответственно, обещаю помочь получить скидки в автосервисе на установку сигнализации, защищающей от угона жены!

Обещаю забронировать где-то 5 мест в детском саду. Сейчас с этим проблемы. 
Опять же, соответственно, обещаю, что помогу в поисках курсов по вождению детских колясок и велосипедов!

В заключение хотелось бы, конечно, пообещать, что возьму над молодой семьей шефство и доведу их до золотой свадьбы!

\section{Обещцание свидетельницы}

1) Обещаю сообщить невесте о новом поступлении ежовых рукавиц в ближайший универмаг!

2) Обещаем приходить в гости только со сладким подарком, чтобы не было ни одного горького дня в вашей жизни!

3) Обещаю помочь в выборе пилы в качестве подарка для мужа!

4) Обещаю помочь избавить нервную систему жениха от потрясений и скрывать от него расходы невесты на свои наряды!

$$
* * *
$$

Дорогие молодожены!

Сегодня все мы свидетели счастливой развязки служебного романа, который, как известно, имеет массу преимуществ перед обычным знакомством.

Вот Вы не задумывались, почему жених сделал такую карьеру? Так же и потому, что он был влюблен. Любовь окрыляет, влюбленный человек чувствует себя счастливым, раньше приходит на работу, чтобы увидеть предмет своей страсти, и не спешит уйти домой. Также у коллег масса общих тем для разговоров, можно обо всем рассказать своей половинке, не боясь, что тебя не поймут. Нет необходимости ждать встречи или телефонного звонка, и каждый обеденный перерыв можно превратить в романтическое свидание. 
А теперь наши жених и невеста могут быть неразлучны ни на работе, ни дома.

В общем, я безумно рад за Вас, дорогие друзья. Будьте неразлучны и счастливы всю жизнь! Пусть Ваша жизнь будет такой же радостной и веселой, как эта свадьба. Пусть Ваш дом будет светлым, уютным для вас и для желанных гостей. Пусть у Вас будут здоровые и умные дети, и будьте верной опорой Вашим родителям.

$* * *$

Даже не знаю, с чего начать. Как любит говорить Минтимер Шарипович, волнительно... Я специально не готовил речь, подумал: скажу все, что буду чувствовать в данный момент. Я испытываю смешанные чувства. (Имя) - один из самых близких моих людей. Конечно, мне грустно, что теперь он не принадлежит только нашей семье. Но, с другой стороны, я счастлив, что он нашел свою вторую половинку.

В сегодняшнем нестабильном мире каждый старается найти для себя нечто постоянное, надежное, не зависящее от внешних обстоятельств. Именно поэтому многие из нас воспринимают семью как убежище, тихую гавань, с которой мы связываем все свои надежды и в первую очередь надежду на счастье.

По моему мнению, семейное счастье строится на взаимопонимании, уважении и бережном отношении к чувствам друг друга, пара должна быть готова преодолеть все трудности вместе и быть готовой к переменам, ведь смысл любви не в том, чтобы не сводить друг с друга глаз, а в том, чтобы одинаково смотреть на мир.

Также я думаю, что это понятие семейного счастья может меняться в каждый период жизни семьи. Например, сейчас наша 
пара счастлива быть вместе, и весь мир замыкается друг на друге. Через какое-то время семейное счастье трансформируется в созерцание первой улыбки Вашего малыша, в гордость за его победы. Счастливая семья - это не мгновения, это долгая совместная счастливая жизнь.

Не надо иметь специального образования, чтобы понять: строительство любого дома начинается с фундамента. Семейное счастье тоже имеет свой фундамент - это, конечно же, любовь. Без любви семейного счастья не построишь, велика вероятность, что оно очень быстро развалится от первых же жизненных трудностей, подобно тому, как карточный домик рушится от дуновения ветра.

Однако одной только любви для семейного счастья мало. Ведь дом - это же не только фундамент, правда?

Помимо любви для строительства семейного счастья нужно также понимание. В счастливой семье всегда царят гармония и согласие между супругами.

Еще один шаг к семейному счастью - уважение.

Следующим кирпичиком на пути строительства счастливой семьи выступает внимание к своему любимому.

Несущей стеной семейного счастья выступает умение просить прощения и умение прощать. Всем людям свойственно ошибаться. Для настоящей семьи важно не столько избегать ссор, сколько избегать их последствий.

По-настоящему счастливая семья немыслима без доверия. Поэтому надо учиться верить тому, кого любишь, как самому себе. Доверие же, в свою очередь, подразумевает искренность в отношениях. 
Как это ни странно, но кроме всего прочего, влюбленным необходима и определенная доля свободы.

Ну и какой же дом может быть без крыши? А крышей семейного счастья - тем, что защищает от снега, дождя и ветра, холода и жары семейных невзгод - является терпение. Главное верить, что проблемы не вечны и что со временем все наладится. И обязательно будет счастье. Независимо от различных факторов нужно ценить то, что у вас есть на данное время. И затем совместно, прилагая максимум усилий, стремиться к лучшему. Таким образом, каждое, даже небольшое изменение, будет приносить огромную радость.

Потому что ваша семья стоит на самом прочном фундаменте, способном выдержать все, что угодно. Помните, что это? Правильно, любовь!

Дорогие молодожены, желаю Вам настоящего семейного счастья, здоровья и огромной любви.

$$
* * *
$$

Дорогие молодые!

От всего сердца поздравляю вас с вступлением в законный брак и образованием семьи!

Обручальное кольцо - славная и многозначительная эмблема. Это символ верности: сердце супруга принадлежит супруге и наоборот. У обручального кольца нет ни начала, ни конца. Обручальное кольцо из чистого золота - значит, к нему не пристанет никакая грязь. Кольцо - символ любви и вечной верности.

Дорогие новобрачные! Пусть ваша любовь будет чиста, нежна и вечна! Подкрепим наше пожелание дружным звоном бокалов! 
Царство семьи - это царство женщины. Умная, добрая, не вздорная жена может, как добрая фея, создать дома атмосферу любви, радости, шутки, юмора, то есть бытие, полное радости, счастья и яркого света.

Мне хотелось бы от всего сердца пожелать молодоженам, чтобы их жизнь была такой же радостной и веселой, как эта свадьба. Но свадьба потому и весела, что виновники торжества дарят остальным радость и веселье и сами радуются.

Вот этот принцип отражения: любите и будете любимы, дарите и будете одариваемы - я хочу рекомендовать как важный жизненный принцип. Да здравствуют жених и невеста! Горько!

$* * *$

Реальная жизнь состоит из множества мелочей, пустых слов, споров, жизненных ситуаций. Жизнь - это гирлянда разноцветных - светлых и пасмурных - дней. И от вашего благоразумия и согласия зависит спокойствие и благополучие вашей жизни, дорогие молодожены! Так пусть повседневные пустяки не портят главного в вашей жизни - счастья и радости. За ваше счастье, молодые!

«Счастье - это когда тебя понимают». Это действительно так. Каждый из нас хочет быть понятым другими людьми, ведь всегда очень важно чувствовать поддержку и уважение окружающих. Я хочу пожелать нашим молодым взаимопонимания и любви на долгие-долгие годы! Счастья Вам, дорогие!

Дорогие новобрачные! От всей души желаю вам отпраздновать в вашей жизни как минимум еще десять свадеб: бумажную через год, стеклянную - через два года, выдержанную - через три года, ситцевую - через пять лет, бронзовую - через десять лет, фарфоровую - через пятнадцать, хрустальную - через двадцать, 
серебряную - через двадцать пять, золотую - через пятьдесят, бриллиантовую - через семьдесят пять лет. А также желаю, чтобы все сегодняшние гости непременно присутствовали на всех этих свадьбах. Давайте выпьем за исполнение этого желания и счастье молодых!

$* * *$

Уважаемые гости! Я рад, что имею честь присутствовать на этой свадьбе.

Прошу Вас обратить внимание, что о женихе и невесте все говорят: (Имя жениха) и (Имя невесты) А мы скажем по-другому: (Имя невестьл) и (Имя жениха).

Наша невеста, безусловно, бриллиант, а жених - достойное обрамление столь драгоценного камня.

\section{$* * *$}

Соединение двух любящих сердец - огромнейшее счастье в жизни любого человека.

В данном случае соединение 2 семейств - это еще и большая удача, так как родственные, да и вообще дружеские связи это бесценный капитал.

Не бойтесь возможных больших и маленьких трудностей на своем жизненном пути, теперь преодолевать их станет легче, поскольку вас двое.

Обращу внимание, доверяйте друг другу, доверие - основа семейного благополучия.

Надеемся, что вы пригласите нас на свою бриллиантовую свадьбу.

Не жалейте о прошлом, не бойтесь будущего, радуйтесь настоящему!

Будьте счастливы. 
Свадьба - служба безопасности.

Дорогие (Имя жениха) и (Имя невесты)!

Вы с нетерпением ждали этого дня. Сегодня знаменательный день в вашей жизни, ваша любящая пара создала семью. Семья - это важный аспект жизни человека, в семье мы любим и радуемся каждому дню, в семье мы находим поддержку и понимание.

(Имя) в профессиональной деятельности отчасти занимается обеспечением безопасности, я думаю, что в семейной жизни это будет залогом комфорта и спокойствия в доме, ведь в современном мире очень важно быть уверенным в завтрашнем дне.

Дорогие молодожены, искренне поздравляю вас с днем бракосочетания, желаю вам здоровых, умных и красивых детей, пусть о вашей семейной жизни можно будет говорить лишь в превосходной степени!

В ваших сердцах сейчас стоит весна. Желаю вам сохранить любовь на всю жизнь, это чувство, которое так красиво назвала чилийская поэтесса Мистраль - «нежный шепот и чувств тетива».

$* * *$

У нас с Вами за окном лето, а лето - это традиционная пора свадеб, свадебное настроение воцарилось и этим вечером; в этом уютном месте. Предсвадебные хлопоты оправдали себя, - я уверен, что молодоженам и гостям этот день запомниться как один из самых веселых и счастливых.

Хотелось бы пожелать, чтобы солнечной и радостной была и дальнейшая, семейная, жизнь этой прекрасной пары - (Имя) и (Имя)! 
(Имя) добился определенных (больших) высот в профессиональной сфере, теперь к его жизненным приоритетам добавилось и создание крепкой, дружной и здоровой семьи, рождение и воспитание ребенка, я думаю, что теперь он будет успевать и в семейной, и в деловой жизни.

Дорогие (Имя) и (Имя)! Пусть вашу семью можно будет назвать идеальной. Я открою вам секрет создания идеальной молодой семьи - она состоит из 3 элементов - это Любовь, Страсть и Уважение.

Уважение интересов друг друга я считаю немаловажным фактором для счастливого брака, ведь семья - это единственная область отношений, где любовь и искренние чувства, а не цель, управляют гармонией.

Живите легко и будьте счастливы!

***

Однажды репортер одной из местных газет брал интервью у одной пожилой пары: «Неужели вы прожили вместе 50 лет и за все это время ни разу не ссорились?»

Жена ответила, что когда они возвращались со свадьбы домой, лошадь споткнулась, и молодой муж сказал «Раз!», когда лошадь споткнулась еще раз, он сказал «Два!», а когда лошадь споткнулась в третий раз, муж достал пистолет и выстрелил лошади в голову. Тогда его молодая супруга закричала: «Что ты наделал, ты зачем застрелил нашу лошадь?!!!» Супруг сказал: «Раз!».

Я желаю новобрачным, чтобы они, несмотря на ссоры, которые неизбежны в нашей жизни, любили друг друга и прожили вместе гораздо больше 50 лет! 


\section{Рождение ребенка}

Вы счастливый человек, у Вас 2 сына. В этом, безусловно, масса преимуществ.

- У Вас 2 сына. Вам, наверное, трудно справиться с ними, мальчики так шумят!

- Ничего, один шумит так, что второго не слышно.

Если, серьезно, мужчинам необходимы дети, чтобы придать новый смысл собственной жизни, чтобы удивляться и радоваться, видя, как они растут, наконец, чтобы приобщиться к их особому способу мыслить и сильным чувствам, которых взрослым порой недостает...

Статус отцовства - одна из центральных задач развития личности взрослого мужчины и критерий ее зрелости.

Поздравляю Вас Днем рождением (Имя)!

(Указать) года - это серьезный возраст, роль отца становится более важной по мере взросления детей, ведь отец это модель мужского поведения.

Пусть в своей жизни (Имя) будет соответствовать значению своего имени. Желаю крепкого здоровья, маленьких и ярких открытий каждый день!

\section{Дорогие родители!}

Рождение ребенка - важное событие в семье. Появился новый человек на земле, родная кровь, наследник, судьба которого в руках его родителей и близких, а каким он станет в будущем во многом зависит от родителей, их ума, знаний, ответственности перед ребенком. Желаем, чтобы он унаследовал прекрасные качества своего отца и своей матери. 
Говорят, что западный ветер несет с собой трудолюбие и деловитость, восточный - мудрость, северный - мужество и целеустремленность, а южный - тепло, мягкость и покой. В тот момент и в том месте, где появился ваш сын, все ветры встретились и передали ему свои качества!

Поздравляем с увеличением семьи! Закон перехода количества в качество подтверждает, что раз семья стала больше, значит, она стала лучше! А значит, можно пожелать только одного чтобы и жизнь ваша стала лучше! Счастья вам и вашему малышу!

\section{$* * *$}

\section{С ПЕРВЫМ ГОДИКОМ ЧУ ДЕСНЫМ!}

ПОЖЕЛАНИЕ МАЛЫШКЕ -

ЧТОБ ЖИЛОСЬ ЕЙ ИНТЕРЕСНО, чТОБЫ БЫЛИ КУКЛЫ, КНИЖКИ, ЛЕНТЫ, БАНТИКИ, НАРЯДЫ, МНОГО НЕЖНОСТИ И ЛАСКИ!!! ЕСЛИ МАМА С ПАПОЙ РЯДОМ ЗНАЧИТ, БУДЕТ ЖИЗНЬ КАК В СКАЗКЕ!

$* * *$

Поздравляю вас с рождением маленькой принцессы! Пусть малышка будет так же обаятельна, как и ее мама, пусть ее жизнь будет долгой и счастливой! Пусть у вашей чудесной семьи все складывается очень удачно!

\section{$* * *$}

Само рождение ребенка есть подарок не только для мамы и папы, но и для новоиспеченных бабушек и дедушек, а также для всех близких друзей, собравшихся за столом. За подарки следует 
благодарить подарками, поэтому сегодня мы приготовили для малыша много подарков, которые пригодятся ему в жизни!

За счастье родителей новорожденного, его бабушек и дедушек!

\section{$* * *$}

Предлагаю выпить за то, чтобы новоиспеченные родители руководствовались в воспитании своего ребенка словами Пифагора: «Берегите слезы ваших детей, дабы они могли проливать их на вашей могиле».

\section{$* * *$}

В мире становится больше любви и света, когда рождается девочка. Вот и сегодня выдался прекрасный, солнечный день. Мир приветствует новорожденную и радуется ей ярким солнечным лучиком, крадущимся к колыбели. Выпьем за новорожденную! Пусть судьба благоволит к ней!

\section{$* * *$}

Говорят, если Бог поцелует новорожденного в лоб - тот станет знаменитым философом, если в уста - знаменитым оратором, если в ножки - знаменитым танцором, если в ручки мастером на все руки. Так пусть же Бог не оставит без внимания нашего новорожденного, пусть его жизнь будет долгой и прекрасной!

\section{$* * *$}

Рождение ребенка - это большая радость, но также и большая ответственность, большой труд. Хочу пожелать вам, чтобы эта радость превосходила все. С новорожденным вас! 


\section{$* * *$}

Если детей находят в капусте, я предлагаю выпить за этот прекрасный овощ! Если детей приносит аист, я предлагаю выпить за эту изумительную птицу! Короче говоря, за первопричину нашего сегодняшнего собрания - за аиста, за капусту, за меня!

$$
* * *
$$

Дорогие вновь испеченные мама и папа! Тысячу лет назад персидский поэт дал молодым родителям очень хороший совет:

«Ребенка воспитай, пока он глуп и мал, Чтоб благородным был, чтоб он разумным стал, Покуда молод ствол, пока лишь зреет плод, Ствол можно так растить, как хочет садовод. Ствол старый выпрямлять и гнуть другой нельзя, Наставить тех, кто зрел, на путь иной нельзя». Поднимем бокалы за мудрое пожелание!

$* * *$

Дорогие родители! В вашей семье пополнение: появился маленький и еще ничего не понимающий человечек. Я от всего сердца поздравляю вас с этим событием и предлагаю тост словами Лермонтова:

«Ребенка милого рожденье

Приветствует мой запоздалый стих.

Да будет с ним благословение

Всех ангелов небесных и земных!

Да будет он отца достоин,

Как мать его, прекрасен и любим;

Да будет дух его спокоен

И в правде тверд, как божий херувим. 
Пускай не знает он до срока

Ни мук любви, ни славы жадных дум;

Пускай глядит он без упрека

На ложный блеск и ложный мира шум;

Пускай не ищет он причины

Чужим страстям и радостям своим,

И выйдет он из светской тины

Душою бел и сердцем невредим!» 


\section{Профессиональная деятельность}

\section{Назначение на должность}

\section{Уважаемые коллеги!}

Хочу представить вам нового начальника (Ф.И.О.). Он окончил в (дата, название института) по направлению (Название) и в (возраст) года поступил в (Название отдела организации).

Всего его стаж - (количество) лет.

(Ф.И.О.) является уверенным и ориентированным на результат руководителем, обладает прекрасными навыками планирования, решения проблем и принятия решений, а также сильными лидерскими качествами.

Есть такой анекдот:

«Претендент на должность пришел на собеседование и уснул на диване в приемной. Когда руководитель его разбудил, он ответил: «Вот видите, как я быстро адаптируюсь на новом рабочем месте».

Про (Имя) тоже можно сказать, что он быстро адаптируется на новом рабочем месте, и, надеюсь, так же быстро адаптируется и на должности (указать).

В заключение хотелось бы напомнить старинную мудрость: «О тех, кто работает на совесть, знают. О тех, кто работает на износ, - помнят». Так что желаю новому начальнику работать на совесть и привести свое новое подразделение на первое место.

$$
* * *
$$

Уважаемая (И.О.)!

Я рад присутствовать на этой неформальной встрече, посвященной Вашему назначению на должность. 
Признаюсь, я был очень рад, что в лице начальника (указать), моего коллеги я вижу лидера нового поколения. Я уверен, что с данного момента (указать), сохранив классические традиции, возьмет принципиально новый курс и темп развития. Я хотел бы пожелать Вам успешно реализовывать инновационные проекты, не опасаясь не соответствовать шаблонам и стандартам, что во многих случаях, безусловно, более легкий путь.

Я уверен, что Вы блестяще справитесь с возложенными на Вас обязанностями. Ведь Вы знаете данный участок работы, так сказать, изнутри, пройдя путь от специалиста и руководителя районного масштаба до масштаба центрального офиса. В таком вертикальном построении карьеры есть неоспоримые преимущества: знание всех деталей деятельности, деловая репутация, имидж, хорошо налаженные рабочие связи.

Итак, искренне желаю успехов во всех начинаниях, смелых и творческих взвешенных решений! Пусть работа принесет радость и профессиональное удовлетворение!

***

От всей души поздравляем Вас с избранием на должность ректора!

Голоса, отданные за Вашу кандидатуру, - лучшее свидетельство поддержки намеченного Вами курса, наглядное подтверждение верности избранной стратегии развития высшего учебного заведения как новейшего классического университета.

Ваша забота о каждом сотруднике, каждом студенте, стремление вникнуть в любую проблему очевидны всем, кто работает или учится в ... университете. Профессионализм и организаторские способности, безупречная репутация и значительный научный вклад находят самый горячий отклик в наших сердцах. 
Мы твердо убеждены, что в ближайшие годы университет под Вашим руководством достигнет новых высот и станет лидером в модернизации российской системы высшего профессионального образования.

Вы не просто руководите университетом - Вы демонстрируете нам пример того, как можно и нужно работать.

Успехов Вам на ректорском посту! И пусть Ваше кредо «ВПЕРЕД!» - будет основным принципом работы нашего коллектива!

Желаем Вам крепкого здоровья, благополучия, успехов в реализации замыслов и планов на благо процветания ... университета.

Современное общество диктует нам жесткие приоритеты: деньги, карьера, власть и другие признаки социального успеха. Несмотря на свой возраст, виновник торжества высоко поднялся по служебной лестнице, и это достойно уважения.

Однако я считаю, что приоритет имеет и личная жизнь человека, чтобы на деле жить лучше - полной жизнью и в ладу с самим собой. Ведь без этого главного условия никакие общепринятые атрибуты успеха полноценной радости просто не принесут, и человек может стать жертвой бесконечной и часто бессмысленной гонки за формальными признаками внешнего успеха.

Согласно древнеримскому философу Сенеке, жизнь делится на две части: negozium, что соответствует обычной активности, призванной обеспечивать наши нужды, и otium, то есть время, посвященное духовному росту, чтению и занятию искусствами. С завершением эпохи Античности и распространением христианства такое понятие, как «праздность», обрело негативный 
оттенок. Но сегодня мы вновь открываем ценность этих свободных от рациональной деятельности минут.

Желаю найти способы полного раскрытия собственных возможностей, чтобы жить, получая удовольствие от жизни и общения с другими людьми!

\section{Проводы на пенсию}

Дорогие коллеги! Мы сегодня собрались по противоречивому поводу, для нас всех - грустному, а для виновницы торжества - радостному.

Римский поэт, мудрствуя, заметил: «Незачем годы считать. Суть не в годах, а в делах - их-то и надо считать». Я думаю, чтобы сосчитать все достижения (И.О.), сегодняшнего дня не хватит.

(И.О.), наш (указать) многое потеряет с Вашим уходом. Вы были музой и вдохновительницей нашей организации, заряжали коллектив интересными идеями, сохраняя и укрепляя деловую репутацию (название)!

Ваша мудрость и женская интуиция помогали сглаживать острые ситуации во взаимоотношениях, которые неизбежно возникают в любом коллективе.

Мы все знаем Вас как необыкновенно талантливого, искреннего и жизнелюбивого человека, наполненного мощнейшей созидательной энергией. Я восхищаюсь Вашим очарованием, благодарю судьбу, подарившую мне знакомство с Вами, возможность внимать Вашим мудрым советам и пользоваться доброй поддержкой. 
В этот праздничный для Вас день хочу пожелать Вам крепкого здоровья, счастья, успешного воплощения в жизнь всего задуманного, радостей от каждого прожитого дня!

Пенсия - это самый лучший отпуск! Это уникальный шанс посвятить себя любимому делу и тем приятным вещам, на которые времени раньше не хватало. Теперь можно погрузиться в те дела, которые доставляют настоящее удовольствие, и окунуться с головой в атмосферу настоящего отдыха!

А завершить свою речь хочу стихами:

«Выход на пенсию - это почетно!

Вас от души в этот день поздравляю.

Новая веха - заслуженный отдых!

Вам всего доброго, счастья желаю.

Пусть беззаботные дни ожидают,

Планы, надежды и светлые встречи.

Радуют дети заботой, любовью,

Внуков звучат рядом смех пусть и речи».

\section{$* * *$}

Сегодня одновременно и торжественный, и грустный момент. Мы провожаем на заслуженный отдых одного из опытнейших руководителей.

Любовь к своему делу, высокое чувство ответственности позволили Вам всегда быть в коллективе единомышленников, работающих как единый организм, успешно решающий задачи. Мы сердечно благодарим Вас за этот долгий и славный путь, за бесценный опыт, за многочисленные знания, переданные каждому работнику. Вы воспитали себе надежную смену, которая Вас никак не подведет! Надеемся, что при выходе на заслуженный 110 
отдых Вы не забудете своих коллег и будете помогать профессиональным советом.

От всей души желаем Вам крепкого здоровья, долгих лет жизни и всегда помнить, что коллеги любят, уважают Вас и всегда рады встрече с Вами. Вы заслужили признательность и уважение коллег за добросовестное отношение к работе, терпение и высокое профессиональное мастерство.

Желаем Вам только хороших перемен, достатка, неиссякаемой энергии, счастья, с оптимизмом смотреть в будущее и наслаждаться заслуженным отдыхом!

\section{Руководителю на годовщину пребывания в должности}

Разрешите поздравить Вас с (...)-летней годовщиной во главе нашей организации!

В чем же секрет Вашего успеха на протяжении этих лет? Секрет должен оставаться секретом, на то он и секрет... Когда все ясно и известно, становится неинтересно. Но знаем одно в Вас сочетаются мудрость и опыт, и, безусловно, природный дар и смекалка!

На наш взгляд, Вы идеальный руководитель, генератор идей и вдохновитель! Вы умеете слышать и понимать своих коллег, воспитывать в них лучшие качества. Только лишь хороший руководитель умеет мотивировать, «растить» своих подчиненных.

Вы обладаете богатым профессиональным опытом, огромным запасом знаний в самых различных областях. Чем бы Вы ни занимались, Вы углубляетесь в суть процесса, умеете аргументированно защитить свою позицию. Для нас, Вашей команды, очень много значит понятие надежности. И пусть некоторые вопросы 
решаются очень непросто, мы всегда уверены, что Вы никогда не откажетесь от своих слов: если решение принято - оно будет исполнено и будет действовать! В этом Ваш талант руководителя!

Зная Вас и работая под Вашим началом, можно сказать одно: человек слова и дела всегда найдет свое место в жизни и всегда будет приносить только пользу людям и государству. Так пусть Ваша приверженность долгу и увлеченность любимым делом всегда отзываются новыми успехами и достижениями!

Поздравляя Вас с этой датой, хотим пожелать Вам - как бы тривиально это ни звучало - прежде всего, здоровья! Потому что жизнь и работа требуют от нас много сил и энергии - и ради нашего всеобщего блага - служения великой стране, и ради собственной семьи!

Редкие люди становятся центром притяжения исторических событий. Еще меньше на свете личностей, способных управлять судьбою мудро, невзирая на препятствия, великие и малые потрясения. На их долю выпадают самые невероятные, самые суровые испытания.

Ваше руководство (Название организаџчи) совпало с эпохой кардинальных перемен в системе (Название системы).

Однако цельность натуры, широта взглядов, острота мыслей и свободолюбия, умение держать мужское слово позволяют Вам, (И.О.), достойно исполнять свой долг.

Это не высокие слова. Это правда, подтвержденная в свое время древнегреческим философом Платоном, который заметил: «Делай свое дело - познай самого себя...» 
Ваш опыт, авторитет, умение работать с полной отдачей сил активно способствуют выполнению важных задач и объединяют усилия сотрудников (Название организации) для эффективной работы на благо нашей страны.

Искренне желаю Вам крепкого здоровья, стабильности и процветания, счастья и благополучия, верных соратников и успехов в реализации ваших планов, счастья, мира и добра Вам и Вашим близким!

$* * *$

- Скажите, сколько Вас здесь работает?

- С шефом - десять.

- А без него?

- А без него никто не работает.

Мой тост за нашего шефа, без которого работать тоже не хочется, но не из-за лени, а ввиду отсутствия настроения из-за отсутствия шефа, но мы работаем, так как (И.О.) нас так воспитал.

\section{День рождения / юбилей организации}

Я рад, что имею возможность присутствовать на вечеринке VIP уровня - ежегодной презентации группы компании (Название).

Итак, (Название) - это талантливая команда, инновационные технологии медиа-планирования, творческий поиск, блестящие идеи, реализация смелых проектов. Бурно развиваясь, вы уделяете внимание высокому качеству контента. Своей работой вы доказываете, что телевидение - это не только успешный бизнес, но и крайне востребованный обществом продукт.

Часы упорного, профессионального труда превращаются в блестящие эфирные секунды. Вы выполняете свою работу с лю- 
бовью, этим объясняется любовь зрителей и признание профессионального сообщества.

От всей души желаю дальнейших свершений, новых партнеров и увеличения числа благодарных зрителей!

$$
* * *
$$

Лето - время, которое каждый из нас ждет с особенным нетерпением... Лето - это долгие вечера, это потрясающие вечеринки на свежем воздухе, жаркое солнце и новые встречи. Это свежая и легкая еда, искрящееся в бокале вино и танцы до упаду.

Также лето - это время обновлений, которые коснулись и кафе (Название). Я рад, что сегодняшний вечер я провожу в столь уютном месте в такой приятной компании по столь приятному поводу.

В (Название) - месте, известном благодаря отсутствию навязчивой рекламы и наличию невероятного интерьера, произошла смена рестораторов. Кафе, расположенное на перекрестке улиц (Адрес), привлекает взгляды всех, кто, так или иначе, направляется в центр города или из него.

Я уверен, что (Название) и в дальнейшем будет пользоваться репутацией прекрасного ресторана, очень популярного, снискавшего себе славу места с отличным обслуживанием и восхитительным гастрономическим меню.

Хотелось бы поздравить людей, связавших свой бизнес с индустрией гостеприимства. Рестораторы, о которых идет речь, представляют собой достойный пример достижения успеха в ресторанном бизнесе.

Предлагаю выпить за процветание ресторана, пожелать владельцам дальнейшего постижения тонкостей и специфики ресторанной сферы! 
Мы уверены, что этот год был годом удачи, успеха и сотрудничества для (Название). Ценности вашей компании остаются неизменными уже много лет: ответственность, профессионализм и высокое качество предоставления общественно значимых услуг.

Ваша организация обладает безупречной деловой репутацией и высоким статусом и, несмотря на высокую конкуренцию на рынке, стремится формировать наиболее приятный климат для развития деятельности всех своих клиентов.

Наше успешное и взаимовыгодное сотрудничество прошло проверку временем. Мы надеемся, что оно продлится на долгие годы.

В канун нового года хотелось бы выразить уважение и признательность за поддержку, открытость и надежность, за понимание и пожелать успехов и удач, стабильности и счастья!

\section{$* * *$}

(Поздравление для телекомпании)

Дорогие друзья!

Всем известно, что в наш век современных технологий и множества телеканалов телезрители ценят не только свежие новости, но, прежде всего, разностороннее, аналитическое освещение событий.

В этом и преуспевает телекомпания (Название), которая входит в крупнейшие негосударственные телевизионные компании России и занимает ведущие позиции в информационной и рекламной индустрии нашего региона.

Я как представитель основной аудитории телеканала экономически активного населения в возрасте от 25 до 54 лет - 
хотел бы поблагодарить сотрудников телеканала за вашу работу, которую трудно оценить «изнутри». Ваша профессия требует таланта, полной отдачи, высокой квалификации, активной жизненной позиции и риска.

Интервью, неожиданные ракурсы, захватывающие сюжеты и интересные телеочерки, а главное - материалы, содержащие анализ и глубокое исследование актуальных проблем, верность своей главной теме и стилю, - вот что сохранит и приумножит аудиторию современного креативного телеканала.

Итак, изменением в сетке телевещания, события, по поводу которого мы и собрались, телекомпания (Название) доказала, что ее приоритетами являются стремление к инновациям и совершенству, создание обстановки, побуждающей сотрудников к развитию собственного потенциала, поощрение в них энергичности и энтузиазма.

\section{$* * *$}

(Поздравление для банка)

Имею честь поздравить руководство и сотрудников банка (Название) с очередной юбилейной годовщиной плодотворной работы! Одним из ярких событий этого года стало открытие вашего офиса в нашем регионе! Масштабность и объем работы, проделанной за это время, вызывают уважение.

Ваша компания, бесспорно, входит в список лидеров отечественного банковского сектора. И это, несомненно, является результатом профессионально реализуемой стратегии по позиционированию бренда (Название) в качестве ведущего частного финансового института России.

Клиенты банка высоко оценивают широкий спектр высококачественных стандартизированных финансовых услуг. 
Мы уверены, что в и дальнейшем миссия вашего банка будет не менее созидательной, значимой и востребованной.

Желаю повышения эффективности управления бизнес-процессами, роста клиентской базы, завоеваний новых сегментов на зарубежном финансовом рынке, а также всех удачных свершений и больших достижений в будущем!

Я рад, что сегодняшний вечер я провожу в столь уютном месте в такой приятной компании.

\section{$* * *$}

Уважаемый (И.О.)! От всей души хочу выразить Вам свою благодарность! Вы превратили наш коллектив в сплоченную команду, которой по плечу любые задачи! Мы рады, что работаем под Вашим началом. От всего коллектива примите искренние поздравления с Новым годом. Ваша энергия и энтузиазм заряжает нас. Мы восхищаемся Вашей мудростью и рассудительностью. Ваша воля и стремление к победе придают нам сил и помогают вести команду вперед. Мы постараемся оправдать Ваши надежды и ожидания.

$* * *$

Жизнь - это слалом, где приходится лавировать между различными обстоятельствами и сталкивающимися интересами, особенно таким деловым людям, как Вы. Пожелаем Вам надежных партнеров, вечных спонсоров, выгодной конъюнктуры и удачного слалома! 


\section{Завершение трудовой деятельности}

Повод сегодняшнего торжества - радостный и грустный одновременно. Радостный, потому что, как говорится, награда нашла героя, и принято решение вручить (Имя) (указать).

Уважаемый (Имя), в нашей организации Вы работаете с ... года. Вы заслужили всеобщее уважение как грамотный, требовательный и принципиальный руководитель. Конечно, работа на такой должности нелегка, как в анекдоте: «Три стопки бумаг: одну надо сделать срочно, вторую очень срочно, а третью вчера...». Но я считаю, что Вы справлялись со своей работой отлично, и в том, что наша организация является самым инновационным и передовым в сфере информационных технологий, в первую очередь Ваша заслуга. От всей души хочу выразить Вам свою благодарность и вручить (указать)!

Однако, к сожалению, придется перейти и к печальному поводу: (Имя) уходит из нашего коллектива. Безусловно, нам жаль терять Вас как ответственного (должность), грамотного специалиста, талантливого и замечательного человека, коллегу.

На Западе бытует мнение, что следует менять место работы как минимум каждые пять лет. Думаю, в этом есть здравый смысл, ведь любое изменение - это движение вперед. Уверен, что накопленный Вами колоссальный опыт станет залогом успешной реализации еще многих проектов в Вашей карьере. Ведь человек слова и дела всегда найдет свое место в жизни и всегда будет приносить только пользу людям и государству.

Наша жизнь похожа на книгу, авторами которой являемся мы сами. И если Вы решили закончить одну главу этой книги, то я уверен, что новая глава Вашей жизни принесет обновление 
и множество сюрпризов. Пусть жизнь ваша будет яркой, щедрой и полной радости! Искренне желаю Вам процветания, крепкого Здоровья и счастья!

$* * *$

В этот день все Ваши подчиненные прежде всего хотят выразить свою искреннюю благодарность. Вы руководили предприятием (количество) лет, и, к сожалению, приходится расставаться с Вами. За время работы Вы создали сплоченную и эффективную команду.

Есть такой анекдот:

«Приходит палач домой. За плечами мешок, в котором чтото шевелится. Жена спрашивает:

- Что это ты несешь?

- Да так, работу на дом взял».

За время работы в (Название) Вам часто приходилось брать работу на дом, ведь Вы многое отдали этой работе, каждый день вкладывая в нее свою душу. Всем жаль терять Вас, но согревает мысль, что перед Вами открывается целый мир, возникают дороги, которые раньше были закрыты. Все то, чему Вы научили своих коллег, непременно поможет нам в дальнейшем.

От всего коллектива и от себя лично хочу пожелать Вам удачи, новых побед и успехов, и, конечно же, крепкого здоровья. Пусть на Вашем пути к новым успехам легко решаются все проблемы, а каждый новый день приносит новые достижения и радость!

\section{$* * *$}

Уверен, что накопленный Вами колоссальный опыт станет залогом успешной реализации еще многих проектов в Вашей 
карьере. Ведь грамотный (должность) - один из самых ценных кадров в любой организации. Уверен, что новая страница Вашей карьеры будет столь же успешной, как и деятельность в нашей организации.

Грустно, что Вы уходите из нашего коллектива, ведь за годы работы Вы заслужили всеобщее уважение как требовательный и принципиальный руководитель, квалифицированный специалист и человек широких интересов. Однако у меня есть уверенность, что мы сохраним дружеские отношения и, возможно, установим взаимовыгодное сотрудничество.

Желаю Вам успехов во всех сферах жизни, неиссякаемой энергии в решении новых задач, крепкого здоровья, благополучия и успехов! 


\section{Календарные даты}

\section{Январь}

\section{Новый год / 1 января}

Есть один известный анекдот:

«Вечером 31 декабря подходит сын к маме и говорит:

- Давай, когда будет половина 12-го, закричим: «Новый год! Новый год!».

- Зачем это?..

- А пусть наши соседи думают, что к нам Новый год раньше пришел».

Сегодня мы собрались здесь нашим дружным коллективом, и к нам Новый год пришел еще раньше, и я рад отметить его вместе с нашей командой.

Но на самом деле - еще несколько дней - и полночь возвестит нам, что прошел еще один год и наступил новый. Мы ничего не знаем о том, что принесет Новый год. Впрочем, мы и не желаем поднимать завесу скрытого будущего. В последние дни старого года мысли наши посвящены более ему, чем Новому году, так как все скрытые человеческие надежды и желания находятся в тесной связи с пережитыми протекшими событиями и происшествиями.

В нашей стране очень любят праздновать Новый год. Его всегда стараются встретить с чистой совестью и без долгов. Я уверен, что и наша организация выполнит все свои обязательства, ведь от нашей работы зависит и праздник в семьях жителей нашей страны, и каждый сможет накрыть праздничный стол и купить подарки. 
$* * *$

Дорогие коллеги! Сразу после праздников наступает время годовых отчетов, сверок, но за всеми цифрами и расчетами стоит кропотливый труд профессионалов, без мастерства которых не мыслим ни один процесс и не воплотима ни одна идея. Уходящий год был успешным благодаря вашим знаниям и опыту, терпению и взаимопомощи, умению работать в команде, уважению друг к другу и преданности общему делу! Надеюсь, что Дед Мороз будет добр к нашим сотрудникам, ведь ему присвоили звание «Ветерана сказочного труда». Пусть наступающий год будет надежным и стабильным для вас и ваших близких, а мечты и цели найдут свое воплощение!

$* * *$

Дорогие коллеги! Очень рад, несмотря на предпраздничную лихорадку, мы нашли время собраться в таком уютном месте.

Зачастую какой-то сложный рабочий вопрос можно решить простым телефонным звонком, если у тебя есть хорошие знакомые в этой организации. Конечно, поддерживать дружеские связи необходимо не только руководствуясь возможной выгодой. На работе мы проводим практически все время. От того, какая психологическая атмосфера сложилась в коллективе, зависит наше самочувствие и работоспособность.

Мне удивительно повезло. За все эти годы совместной работы сложился уникальный коллектив настоящих опытных профессионалов. Хочется заметить, что новые сотрудники очень органично вписываются в наше братство, вернее, даже сестринство, принося какую-то изюминку.

Говорят, что короля славит его свита. Мой успех - это успех, прежде всего, моих сотрудников. Я своей свитой горжусь и 
уверен в ответственности, надежности, лояльности и профессионализме своих коллег.

Дорогие коллеги! Скоро Новый год - самый волшебный и любимый всеми праздник. Это день, который подарит настроение всему году, - ведь известно: как Новый год встретишь, так его и проведешь! Желаю вам незабываемой встречи года (указать) в кругу близких и любимых людей! Желаю вам счастья и здоровья, пусть вас накроет волной хорошего настроения и ярких впечатлений в новом году!

$* * *$

Новый год - это праздник, рубеж, когда мы сводим баланс наших достижений и неудач. Все мы с вами в уходящем году сделали очень многое, чтобы приблизиться к достижению нашей главной профессиональной цели - успеху (Название организациии).

Уважаемые коллеги! Предлагаю тост за нашу организацию и за ее руководителя (Ф.И.О.).

Многие успешные люди считают, что секрет успеха - это огромная работоспособность сотрудников, помноженная на безграничную преданность своему делу. Думаю, вводимые инновации свидетельствуют о том, что и он обладает данным секретом.

Доверие, которым мы заслуженно пользуемся у своих клиентов и партнерских организаций, - яркий пример того, как много можно сделать, если организаторский талант руководства и правильное позиционирование помножить на стремление работать на благо страны и людей. Я уверен, что опыт, богатые традиции и сплоченная команда и впредь позволят нашей организации быть лидером. 
Нашему коллективу хочу пожелать новых горизонтов для развития, грандиозных свершений, крепкого здоровья и долголетия. Пусть вашим новым желаниям и целям в год (указать) сопутствуют удача и сила, чтобы всего этого достичь!

\section{$* * *$}

С Новым годом! В смысле - счастьем! С новым счастьем! То есть вот с чем:

С новой крышей! С новым домом! С новым блином! С новым комом!

С новой правдой! С новым сном! С новой стопкой кверху дном!

С новым делом! С новым словом! Рыболовов - с новым клевом!

Карьеристов - с новым чином! Маму с папой - с новым сыном!

Лесорубов - с новой рощей! Новых зятей - с новой тещей!

Новых русских - с новой тачкой! C новой банковской пачкой!

Бюрократов - с новой папкой! Волосатых - с новой шапкой! Лысоватых - с новой кепкой! Деда с бабкой - с новой репкой!

Зодиака - с новым знаком! Греку в реке - с новым раком!

Донжуанов - с новой милой! Ветеранов - с новой силой!

Бизнесменов - с новым взлетом! С новым банком! С новым счетом!

Кулинаров - с новым вкусом! Импортеров - с новым курсом!

Бомбардиров - с новым голом! Трансвеститов - с новым полом!

Космонавтов - с новой высью! Тугодумов - с новой мыслью! 
Шахматистов - с новым ходом! Вас - еще раз с Новым годом! Музыкантов - с новым звуком! Папуасов - с новым Куком! Капитанов - с новым коком! Президентов - с новым сроком! Депутатов - с новой Думой! Кто за деньги - с новой суммой! Птицеловов - с новой птичкой! А сержантов - с новой лычкой!

Генералов - с новой частью! Вас - еще раз с новым счастьем!

Подчиненных - с новым боссом! Программистов - с новым DOSom!

Слабовольных - с новой дозой! Хатха-йогов - с новой позой!

Пивоваров - с новым суслом! Перестройку - с новым руслом!

Безработных - с новым местом! Тили-тили - с новым тестом!

Сталеваров - с новой плавкой! Отсидевших - с новой справкой!

Похудевших - с новой формой! Бывших трезвых - с новой нормой!

Завязавших - с новой мерой! Атеистов - с новой верой!

Резидентов - с новым кодом! Всех вас - снова с Новым годом!

C новой песней! C новым танцем! Разведенных - с новым шансом!

Жен любимых - с новой шубой! Дядю Сэма - с новой Кубой!

Беззаветных - с новым дзотом! Сокращенных - с новым КЗоТом!

Театралов - с новой драмой! Маму с мылом - с новой рамой!

Журналистов - с новым слухом! Медиумов - с новым духом!

Чукчей - с новым анекдотом! Мчащих - с новым поворотом!

Взявших прикуп - с новой мастью! Всех вас - снова с новым счастьем! 


\section{$* * *$}

Новый год - это праздник, связанный с новыми надеждами на позитивные изменения в нашей жизни, это праздник, окруженный волшебством, в которое хочется верить, загадывая желания и ожидая их исполнения. Чудесное время - конец и начало нового, переход и соприкосновение прошлого и будущего.

Пусть все ваши желания исполняться и все цели, которые вы ставите перед собой, в Новом году осуществятся!

Пусть Новый год принесет вам радость, душевный покой и счастье!

\section{$* * *$}

Уходящий год дарил нам радости встреч и открытий, были маленькие и большие победы и достижения, мы обрели новый бесценный опыт жизни.

Новый год - это одновременно и праздник, и хороший повод подвести итоги, наметить новые цели.

Пусть ваши самые заветные желания сбудутся и наступающий ... год запомнится вам как яркий, успешный и счастливый!

Известно, что в Италии есть традиция - в Новый год выбрасывать старую мебель. Так давайте последуем итальянцам и выбросим все ненужное из нашей жизни - весь хлам обид, разочарований, болезней... И начнем все с чистого листа, со светлой душой, мыслями и сердцем! И я уверен, что тогда нам везде и во всем будет сопутствовать удача, богатство и здоровье! 
До наступления долгожданного Нового года осталось так мало времени. А сколько еще всего нужно успеть сделать. Мы ждем его с нетерпением, потому что это самый сказочный праздник. Это прекрасный повод восстановить отношения, взглянуть на мир по-новому, удивительный шанс перевернуть свою жизнь и оставить все плохое, что накопилось, в уходящем году. А Новый год начать с чистого листа, хорошего настроения, счастья, взяв с собой только лучшее. Ведь именно в эту ночь совершаются чудеса. С наступающим Новым годом!

\section{$* * *$}

Нельзя встретить один и тот же Новый год дважды... И поэтому, чтобы прожить его как следует, нужно его как следует встретить! Желаем вам хорошо его встретить!

$$
* * *
$$

Новый год не роскошь, а средство передвижения во времени! Поздравляю вас с этим шикарным, стремительным, красивым, мощным... праздником и средством передвижения!

***

По традиции мы отмечаем Новый год шампанским. Пусть наша жизнь в новом году будет такой, как это шампанское, легкой, волнующей, прекрасной и бьющей через край. Пусть в Новом году у нас появятся много хороших друзей, грандиозных проектов и возможностей для их воплощения! 
Поднимаю свой бокал за то, чтобы в следующем году было столько хороших новостей, событий и друзей в вашей жизни, сколько ярких огоньков сейчас светится на нашей елке!

Новый год - с детства самый долгожданный и радостный праздник в году. Под бой курантов загадывают сокровенные желания и встречаются с близкими друзьями!

Мы искренне желаем вам, чтобы каждый Новый год добавлял больше радости в наших глазах от совместного сотрудничества, а задачи, которые мы ставим и решаем вместе, обеспечивали не только социальное развитие России, но и приносили ощущение комфорта и душевного благополучия.

У нас есть все возможности, чтобы достичь более высоких рубежей. Новый шанс, предоставляемый новым веком, новым годом, не должен быть упущен. Все мы вместе и каждый в отдельности должны быть не созерцателями, а активными созидателями своей судьбы и судьбы всей своей страны!

Поздравляем вас с наступающим Новым годом! Пусть в будущем году вам улыбается удача и окружают приятные люди, будет много радостных и светлых событий в вашей жизни, вы будете здоровы, у вас будут любовь, внимание и забота - в общем, все то, что называется одним коротким, но значительным словом - счастье!

$* * *$

Звон бокалов, запах еловых веток, блеск разноцветных шаров - из всего этого, как из чудесной мозаики, складываются новогодние праздники. 
Желаем встретить Новый год в кругу Ваших самых близких и любимых людей, за праздничным столом, любоваться сверкающей, нарядной елкой, вдыхать запах мандаринов, приправленный ароматом свежих еловых веток.

(И.О.), являясь (должность), Вы обладаете репутацией грамотного, авторитетного руководителя, способного решать любые сложные задачи. В Новом году желаем Вам реализации всего, что задумано для упрочения авторитета вашей организации на российской пространстве, покорения новых вершин, успешной реализации самых смелых проектов и верности добрым традициям, добра и счастья, крепкого здоровья и долголетия!

Пусть так же сложится для Вас наступающий год из радостных встреч, теплых улыбок, исполнения всех желаний!

Поздравляю Вас с волшебным и веселым зимним праздником - Новым годом!

По праву во всем мире он считается самым любимым, потому что несет в себе радость, доброту и ожидание счастливых перемен.

Этот сказочный праздник мы любим с детства, с ним связано ожидание чуда. Его всегда ждут с волнением, к нему поособому готовятся. Не зря же говорят в народе: «Как встретишь Новый год, так его и проведешь!». Но чтобы его достойно встретить, нужно весь год трудиться, учиться, делать много добрых и полезных дел - своим близким, своей организации, региону и всей стране.

Новый год объединяет и согревает родных людей, друзей, коллег, дарит нам надежду на успешное будущее. С боем курантов мы отсчитываем первые минуты нового года и верим, что он будет счастливым, полным значимых событий, интересных встреч. 
Уважаемый (И.О.)! Пусть Новый год будет богат на удачу! Пусть рядом будут любимые и друзья! Пусть осуществятся самые смелые мечты! Любви, здоровья и достатка!

Уходящий год был для всех нас годом напряженного труда и значимых событий, каждому из нас он запомнится чем-то особенным. Мы многого достигли, и уверен, что свойственные Вам трудолюбие, самоотверженность, сила духа и любовь к работе станут залогом достижений и побед в новом году во благо стабильно и динамически развивающейся страны.

Вступая на порог Нового года, мы с благодарностью оглядываемся назад и вспоминаем все то хорошее, что сопутствовало нам все 365 дней уходящего года. И надо признать - доброго, позитивного было немало. Новый год принесет множество старых и новых забот, впереди еще много нерешенных задач. Однако, уверен, что общими усилиями мы сможем их благополучно реализовывать и добиться серьезных успехов и результатов. Еще раз с наступающим праздником!

\section{$* * *$}

Уважаемые коллеги! Позвольте сердечно поздравить вас с наступающим Новым годом! Совместные торжества сплачивают коллектив ничуть не меньше, чем трудовые будни. Как известно, наступает не просто год Петуха, а год Огненного Петуха.

В русском языке даже существовало выражение: пустить красного петуха - устроить пожар. Вообще, Петух - достаточно распространенный персонаж, вспомните хоть сказку Пушкина «О золотом петушке». Он символизирует смелость, бодрость, яркость, каждое утро своим криком приветствует солнце и наступление нового дня. 
Есть одна старинная китайская сказка: в древности на небе сияло 9 солнц, и люди страдали от жары. Тогда они попросили охотника сбить с неба солнца. Он сбил 8, а одно солнце спряталось за горой, и стало темно и холодно. Тогда люди решили вызвать солнце, и стали решать, кого послать за ним. Сначала выбрали иволгу, но своей красивой песней она не смогла вызвать солнце. Тогда полетел жаворонок, но солнце и не думало появляться. Запел соловей, но и он потерпел неудачу.

И тут люди вспомнили про петуха. Узнав, в чем дело, петух захлопал крыльями, вытянул шею и закричал. Хотя его голос был и не хорош, но в нем чувствовались искренность и бодрость, и сердце солнца дрогнуло. И когда петух прокричал три раза, солнце не выдержало, доверилось голосу петуха, и вновь засияло на небе. С тех пор так и повелось - как петух прокричит три раза, солнце сразу и выходит.

$* * *$

Один старый и мудрый китаец растил бойцового петуха для императора. Прошло десять дней, и император спросил:

- Готов ли петух к поединку?

- Еще нет. Ходит заносчиво, то и дело впадает в ярость, ответил старик.

Прошло еще десять дней, и император задал тот же вопрос.

- Пока нет. Он все еще бросается на каждую тень и на каждый звук.

Минуло еще десять дней, и китаец вновь ответил императору:

- Пока не готов. Смотрит гневно и силу норовит показать.

Спустя еще десять дней император снова спросил, готов ли петух. 
- Готов, - ответил старик. - Даже если рядом закричит другой петух, он не беспокоится. Посмотришь издали - словно из дерева вырезан. Жизненная сила в нем достигла завершенности. Другие петухи не посмеют принять его вызов: едва завидят его, как тут же повернутся и убегут прочь.

\section{Старый Новый год / 13 января}

Чем славен русский человек? Правильно! Тем, что он никогда не упустит лишнего повода для праздника души! А сегодня вполне серьезный повод - Новый год по старому стилю. Я хочу вам пожелать в этот праздник всевозможных благ. Пусть уходящий год заберет с собой все лихо, беды, печали и сложности. А этот Новый год по протоптанной дорожке тихо войдет в наши дома и принесет с собой немножечко добра и сердечного тепла. Пусть он заметет в ваш дом все то, что приходит к нам в эти чудесные праздники: счастье, веселье, радостный смех, внимание близких и родных людей. Пусть он принесет вам азарт к жизни и прекрасное настроение. Пусть нальет вам большой ковшик здоровья и душевных сил, энергии. Желаю вам, чтобы окружающий мир был к вам приветлив, чтоб не было в нем места грусти и печали, чтоб росли с каждым днем ваши доходы и воцарилась финансовая стабильность. Чтоб мороз зимы принес вам бодрость для достижения главных целей. Любви вам большой и человеческого тихого счастья.

\section{$* * *$}

Пролетели в праздничном веселье две недели после Нового года, и вот он снова с нами, только уже по старому стилю. Вот же повезло-то как! Мы только недавно доели все вкусности, что готовили к новогодней ночи, а сегодня примемся резать новые 132 
салаты. И снова наш дом заполнится гостями, улыбками, смехом, подарками, сюрпризами, запахами вкусной еды и звоном хрустальных бокалов. Вот, близится праздничный вечер, и все в сборе! Так давайте же снова поднимем наши полные бокалы и выпьем за большую любовь, удачу, за финансовое благополучие, крепкое здоровье. За то, чтобы судьба была к нам щедра, чтобы беды миновали. Чтобы к нам пришло и осталось навсегда счастье! Выпьем за то, чтобы вот в таком дружном составе еще как минимум сто раз встретить Старый Новый год!

$$
* * *
$$

Сегодня в преддверии Старого Нового года я попрошу у всех святых счастья для тебя, чистого и безоблачного неба, что будет сиять над тобой. Пусть они бережно охраняют тебя от всех невзгод и превратностей судьбы, от бед, обид и разочарований, от злых и завистливых людей, от предательств и несправедливости. Пусть помогают тебе во всех делах, во всех твоих начинаниях. Пусть направляют тебя к целебным источникам жизненной силы, энергии и вдохновения. Пусть сегодня к нам пришел хоть и старый, но все же новый год. Мы усадим его с нами за щедрый стол и поприветствуем. Пусть у тебя будет всегда так же светло на душе, как сегодня, так же сытно в жизни, как на сегодняшнем столе. Пусть в кошельке всегда будет столько денег, чтобы хватало не только на повседневные запросы, но и на исполнения различных желаний. Пусть всегда будет тепло в твоем доме и в твоих отношениях с близкими людьми.

$* * *$

Лишь наш народ может себе позволить такую невиданную роскошь - отмечать Новый год не один, а целых два раза! 
А почему бы и нет? Ведь праздник это же не просто повод для застолья, это повод еще раз собрать вместе семью, друзей, подарить друг другу частичку себя, своего тепла, своей любви и заботы. Я от всего сердца поздравляю вас с праздником, который имеет такое забавное название - Старый Новый год. Пусть он с собой принесет чудесную погоду, много белого пушистого снега. Пусть захватит для вас коробочку с сюрпризами, в которой окажутся и радость, и здоровье, и финансовое благополучие, и любовь взаимная и много-много всего, что вам сейчас так необходимо. Пусть в этом году исполняются все мечты, оправдываются надежды, и ни одно очарование не приведет к горькому разочарованию. С праздником вас, будьте счастливы.

Поздравляю тебя, мой дорогой, с праздником, что второй раз врывается в наши дома, неся килограммы радости и веселья. Поздравляю тебя со Старым Новым годом. Я хочу тебе пожелать добра и большого земного счастья. Чтоб было множество в этом году личностных достижений, и быть может, даже рекордов над самим собой. Желаю тебе каждое утро этого года просыпаться в хорошем расположении духа, в приподнятом настроении, чтобы ты был наполнен жизненными силами и энергией. Я желаю, чтобы не было счета счастливым светлым дням. Чтобы в этом году ты встретил новых интересных людей и укрепил связь с уже близкими и родными тебе людьми. Пусть твоя работа тебя не только морально радует, но еще и денежно. Пусть все неприятности отправятся провожать ушедший год и не найдут дороги назад. Я желаю тебе свершений, значимых приятных событий, чтоб успех и радость кружили тебе голову. 
Bсе запасы шоколадных конфет и мандаринов уже давно съедены, выпито все шампанское и вино, все фужеры бережно перемыты и спрятаны в шкаф. И вдруг, вот тебе раз - снова наступает Новый год! Как некоторым его осилить, ведь у них может быть и головы уже очень плохо варят от двух недель праздников, да и печень подустала. А тут такое событие, не можем же мы его пропустить, не заметив, не отметив? Конечно же, нет! Так пошли же встречать праздник, что уже давно стоит у ворот, ожидая нашего приглашения. Да здравствует Старый Новый год! Я поздравляю вас с этим замечательным и даже немного волшебным событием и по случаю хочу пожелать вам в связи с двойным праздником двойной порции здоровья, счастья, любви. Двойного потока энергии и вдохновения. Пусть денег будет не миллионы, а вдвое больше. Пусть вдвое больше будет поводов для веселья. Любите друг друга в два раза сильнее! С праздником!

В этот зимний тихий вечер подкрался совсем бесшумно Старый Новый год и окрасил наш мир красками волшебства. Загадай поскорее самое заветное, самое важное желание, и светлые, добрые силы его обязательно исполнят! Я хочу тебе пожелать большого везения, как в важных, крупных делах, так и в мелочах. Я желаю тебе миллионов различных возможностей, чтобы можно было достигнуть любой цели легко и просто, получив при этом невероятное удовольствие от самого пути к этой цели. Я желаю тебе такого года, чтобы он навсегда остался сладкими воспоминаниями твоей души. Пусть все, что не произойдет в нем, будет тебе приятно. Пусть все события делают 
тебя счастливыми. Я желаю тебе только добра и огромного счастья. Поздравляю с праздником Старого Нового года!

Пусть старый год по уже сложившейся замечательной традиции заберет с собой все наши невзгоды, печали и проблемы. Давайте проводим и его и с открытым сердцем встретим Новый год по старому стилю. Пусть этот год проложит путь счастью и любви к твоему сердечку. Я желаю сполна познать тебе все прелести этой жизни, чтобы все у тебя получалось, любое дело удавалось быстро и ладно. Чтобы в тебе всегда жило волшебное вдохновение, которое бы рождало в твоей голове новые креативные идеи. Чтобы у тебя всегда была сила духа и целеустремленность воплощать свои идеи, смело шагать по выбранному пути, не обращая никакого внимания на проблемы и преграды, на зависть и подлость других людей. Пусть тебе все и всегда будет по плечу. С Новым годом тебя, со Старым Новым годом, счастья тебе, любви и удачи!

\section{$* * *$}

Сегодня наступил волшебный праздник, который дает нам еще один шанс повторить все то, что мы делали несколько недель назад. Мы снова можем класть под елочку подарочки, накрывать щедрые столы, уставляя их разнообразными вкусностями. Нам снова выпала удивительная возможность загадать в новогоднюю ночь свои заветные желания в надежде на их скорейшее воплощение в реальной жизни. У нас есть еще один повод порадовать своих родных, близких, любимых людей. Подарить им подарки, свое тепло, заботу, выпить с ними шампанского и пожелать всех благостей жизни. В этот день как никогда хочется стать снова 
маленькими детьми и прочувствовать всю сказочную атмосферу. Я хочу в такой час пожелать вам, чтобы в вашей жизни было как можно больше волшебства и приятных сюрпризов. Поздравляю вас с наступившим праздником - Старым Новым годом.

\section{$* * *$}

Каждый год, мы с большим нетерпением и особым трепетом ждем этого праздника - Старого Нового года. И пусть мы еще ни капельки не отдохнули от празднования Нового года, наши сердца снова открыты чудесам, веселью и доброте. А особую гордость мы чувствуем потому, что это только наш праздник, наша особенность встречать Новый год два раза. Поэтому Новый год уж точно не останется в обиде, мы его отпразднуем по богатому, как следует. И если вдруг в первый раз тебе что-то не удалось, не успел кого-то поздравить, подарить подарок или сказать важные слова, ты можешь это сделать сегодня. Если ты вдруг на Новый год не успел загадать свое заветное желание для Вселенной - ты можешь это сделать сегодня. И даже если в Новый год у тебя все получилось, прими с благодарностью эту возможность лишний раз порадовать близких людей и себя. Хорошего и доброго тебе праздника, поздравляю!

Все мы, даже если вслух никому не говорим об этом, в тайне, в глубине души, склонны верить в чудо. Сегодня пришел к нам замечательный и сказочный праздник - Старый Новый год! А значит, перед нами открывается новая страница жизни! Я желаю тебе вступить в этот год с самым лучшим настроением, с самыми душевными и светлыми чувствами. Пусть это волшебство живет у тебя в сердце весь следующий год и радует тебя, и согревает, 
и придает тебе сил. И если вдруг тебя что-то огорчит или рассердит, если вдруг ты захочешь поругаться - остановись и вспомни этот трогательный момент волшебства. Вспомни счастливые лица и улыбки своих родных людей, своих друзей, вспомни их искрящиеся глаза и все добрые слова, которые они произнесли для тебя. И в твоем сердце сразу же все изменится. А жизнь непременно отблагодарит тебя за оптимизм и доброту. Поздравляю со Старым Новым годом!

\section{$* * *$}

Дорогие мои друзья, что я вам хочу сказать: елочка стоит, красавица наша, такая же красивая, такая же свеженькая, как и несколько недель назад, свечи горят, стол ломится от всевозможных изысканных блюд, шампанское разлито по бокалам. Вы все такие радостные, счастливые, нарядные и красивые! А что это значит? Правильно! Сегодня нам выпал уникальный шанс отпраздновать Новый год еще раз. Повторить все то приятное, что случилось с нами. Еще раз пожелать друг другу блага и одарить лучами своей любви и добра. Я хочу пожелать вам от всей души, чтобы все последующие дни этого года вы себя чувствовали такими же счастливыми, радостными, полными сил и желания жить. Пусть этого новогоднего настроения, этих волшебных эмоций хватит на целый год! Конечно, не обойтись нам без проблем, ведь мы люди молодые, деятельные, поэтому я желаю вам, чтобы они легко и быстро решались. Пусть все у вас будет хорошо! 


\section{Татьянин день.}

\section{День российского студенчества / 25 января}

Наверное, самые веселые и деятельные времена в жизни человека - это студенческие годы, годы свершений, влюбленностей, порывов и разочарований. Каждый день несет что-то новое, необычное, свежее в восприятии. И не беда, даже если уже и не студент вовсе, главное внутри не потерять ту нить, что связывает воедино студенческое братство. Поздравляю всех студентов: бывших, настоящих и будущих, и желаю провести этот день так, чтобы было о чем вспоминать целый год, а лучше - всю жизнь!

\section{$* * *$}

Студенчество - воистину лучший период жизни. Желаю вам прочувствовать на себе все его прелести. Пусть учеба дается легко, экзамены сдаются быстро, а свободного времени будет все больше. Желаю вам направлять весь присутствующий энтузиазм в нужное русло. Пока жизнь предоставляет вам все возможности, берите от нее все. Пусть годы, что пролетают так быстро, оставят в вашей памяти неизгладимый след радостных и положительных впечатлений.

\section{$* * *$}

С Днем студента! Студенты - народ предприимчивый, изобретательный, а студенческая пора - самая веселая в жизни. Хочу пожелать веселой учебы и легкой сессии, хороших оценок и запоминающихся моментов, о которых хотелось бы вспоминать и спустя многие годы! С праздником!

\section{$* * *$}

Дорогие студентики! Сегодня самый безбашенный праздник, который может праздновать учащийся человек, - День студента! 
Пусть стипендии хватает на джипики, в зачетке блестят одни пятерики, каждый день греют крепкие обнимашки любимого человека и друзей. Студент, помни, праздник - праздником, а учеба ждать не будет. Пусть соберутся сегодня все друзья и зашумят громким смехом, разговорами и танцами. С праздником!

\section{Февраль}

\section{День святого Валентина.}

\section{День всех влюбленных / 14 февраля}

Поздравляем с Днем святого Валентина!

Пусть каждый день будет наполнен теплом и солнечным светом независимо от прогноза погоды. Пусть любовь окрасит Вашу жизнь в яркую гамму чудесных эмоций! А если Ваше сердце пока одиноко, значит, Ваша половинка просто тщательно готовится к предстоящей встрече... Желаем жаркой любви, пламенной чувственности и нежной романтики!

\section{***}

День святого Валентина - один из самых романтичных праздников в году, это день, когда можно признаться в своих чувствах или напомнить о них любимому человеку.

В каждой стране существуют свои традиции празднования Дня святого Валентина. Так, в Дании возлюбленным посылают засушенные белые цветы, а искушенные в любовной премудрости французы дарят драгоценности.

Желаем Вам восхитительных цветов и галантных поклонников, внимания, нежности, заботы любимого человека, теплоты и любви сердец! 
Я хочу сказать один тост про любовь, точнее, это диалог в лицах.

- Так, - подвел итог Разум, - мы влюбились. Это прекрасно, но кого мне за это благодарить?

- Нас, конечно, - сказали Глаза, - мы ее первые увидели!

- Ха, - сказали Уши, - по-вашему, был бы он слепой - не влюбился бы? Нет, это именно через нас он услышал нежный голос!

- Дураки, все дело в феромонах или как их там! - хмыкнул Нос. - Современная химия доказала, что именно через запах...

- А зато мы ее первые потрогали! - перебили Руки.

- А не будь нас, он попросту не смог бы к ней подойти, важно заключили Ноги.

- А ты что в это время делало? - обернулся Разум к Сердцу. Оно покраснело:

- А я... да ничего... я так растерялось...

И Разум улыбнулся, потому что он понял...

За любовь, которая зарождается в наших сердцах! С Днем святого Валентина, Днем всех влюбленных!

$* * *$

Один молодой человек влюбился в девушку. Но поскольку был очень робким, то никак не решался хотя бы приблизиться к ней. И вот однажды он нашел выход и стал писать девушке письма. И в этих письмах рассказал своей любимой о том, что чувствует, насколько это чувство делает его счастливым. И все свои письма он опускал в почтовый ящик. 
Время шло, а молодой человек оставался смелым только в письмах. Так прошла зима и наступило лето. И однажды он услышал от людей, что его возлюбленная выходит замуж за другого. И этот другой - почтальон, который приносил ей письма.

Робость мешает человеку быть собой, и поздравляя Вас с Днем влюбленных, желаю Вам оставить робость и смело говорить о своих чувствах!

\section{$* * *$}

Поздравляю Вас с неофициальным, но от этого не менее прекрасным праздником - Днем всех влюбленных! Любовь, как известно, почти всегда нечаянно нагрянет и именно тогда, когда ее абсолютно не ждешь. Вот в этом и весь фокус. Помните себя в таком состоянии? Когда, казалось, что весь мир поет и вы ему подпеваете. Когда внутри Вас бабочки порхают и ласково так щекочут. Когда перед глазами только одна картинка - это предмет Вашей влюбленности. И не хочется убирать эту картинку, хочется только, чтобы она почаще материализовывалась.

Влюбилась по уши, и вот:

Мозг мой в тумане, душа поет,

Внутри порхание какое,

И небо чудно голубое.

И люди ласково глядят,

А аромат... а аромат...

Как будто в райский сад попала,

И возвращаться не хочу.

Как будто к солнцу я лечу... 


\section{День защитника Отечества / 23 февраля}

День защитника Отечества - самый «мужественный» праздник в году. Для одних - это памятная и торжественная дата, для других - просто хороший повод собраться с друзьями. Так или иначе, но День защитника Отечества - это, прежде всего, государственный праздник, насчитывающий уже более чем восьмидесятилетнюю историю.

Считается, что День защитника Отечества возник в 1918 году как день рождения Красной Армии в ознаменовании победы под Нарвой и Псковом над германскими завоевателями. Однако ни в этот день, ни вообще в феврале 1918 года не было никаких побед над немцами. Только в 1922 году этот день стал праздником и получил следующее название: День Красной Армии. С 1946 года он стал называться Днем Советской Армии и Военно-Морского флота.

Хотя День защитника Отечества сегодня воспринимается скорее как «мужское восьмое марта», стоит помнить, что в первую очередь поздравлений заслуживают те, кто в разные годы защищал нашу Родину, и те, кто сейчас оберегает наш спокойный сон. Те, кто на протяжении десятилетий доказывали безграничную любовь к Родине, преданность Отчизне, верность долгу и присяге, храбрость в боях, дисциплину и порядок в несении службы. Все эти бывшие, нынешние и будущие защитники Отечества, конечно же, рассчитывают получить подарок к празднику.

Уважаемые воины Российской армии, ветераны Вооруженных Сил! Сердечно поздравляю вас с Днем защитника Отечества! Это праздник мужественных, верных воинскому долгу людей, кто честно и преданно служит России, кто живет ее интересами. Защищать Родину можно по-разному. Ученые укрепляют ее 
обороноспособность новейшими открытиями, инженеры - передовыми технологиями, работники ВПК оснащают армию современным оружием. Но есть еще и те, кто с оружием в руках, с риском для жизни стоят на страже рубежей своей Родины. Во все времена звание защитника Отечества звучало в России гордо, носители этого звания были окружены особым почетом и уважением. Боевая слава армии и флота, незыблемые воинские традиции защитников Родины были и остаются предметом национальной гордости россиян. Патриотизм, мужество, стойкость, сила духа, вера в победу всегда отличали тех, кто верой и правдой служил Отечеству. В памяти народа навсегда останутся подвиги многих поколений воинов, в годы суровых испытаний отстоявших свободу, независимость и целостность родной земли. В День защитника Отечества мы отдаем дань памяти героям Великой Отечественной войны. Уважение к истории государства, гуманизм, профессионализм и сплоченность, понимание важности поставленных задач сегодня - ориентир для всех, кто несет сегодня воинскую службу в рядах Вооруженных Сил Российской Федерации, кому еще предстоит пополнить армейские ряды. От всей души желаю всем, кто достойно выполняет свой воинский долг, несет срочную службу в рядах российской армии, успехов в их нелегком труде, а ветеранам - крепкого здоровья и счастья, мира и благополучия!

\section{$* * *$}

Февраль - самый суровый месяц года! Может быть, именно поэтому самый большой и суровый мужской праздник появился в феврале? Защита Родины - привилегия и обязанность настоящих мужчин! А ведь работа, дети, родители, семья - это тоже маленькая частичка Родины, которую нам приходится защищать! 
Желаю вам и себе тоже, чтобы наши силы и умения находили применение только в мирных целях, на благо и процветание нашего Отечества. Здоровья, успехов и добра вам и вашим близким!

23 февраля - это День защитника своего Отечества, своей семьи, чести своей компании. 23 февраля - это День настоящего мужчины. В День защитника Отечества желаю позитивного настроя и больших карьерных высот, здоровья и бодрости!

Этот подлинно всенародный, один из самых почитаемых россиянами праздник - символ мужества и патриотизма.

В этот день слова поздравления звучат для всех настоящих мужчин - деятельных, сильных, которые защищают от трудностей и невзгод свои семьи, несут ответственность за настоящее и закладывают крепкий фундамент в будущее нашей страны.

Желаю всем, кто встречает праздник в кругу родных, и тем, кто находится на боевом посту, здоровья, стойкости духа, верных друзей, домашнего уюта и тепла!

23 февраля - праздник, превратившийся из профессионального в общегосударственный. Он напоминает всем российским мужчинам о том, что они мужчины, надежда и опора для тех, кто рядом. Истинно мужские качества - храбрость, умение брать на себя ответственность, чувство долга - всегда в цене.

В этот праздничный день всем мужчинам и себе в том числе желаю оптимизма, уверенности в завтрашнем дне, крепкого здоровья и мирной жизни! 
$* * *$

23 февраля - праздник истинных мужчин, смелых и отважных, которые из любых ситуаций выходят победителями. Воинысотрудники нашей организации, защитники хрупкого женского счастья, пусть все желания, загаданные вами, исполняются с легкостью, а жизнь будет счастливой и радостной!

$* * *$

С превеликим удовольствием хочу поздравить наших замечательных коллег с истинно мужским праздником - 23 февраля! Вы верные друзья и защитники интересов в работе. Желаю дальнейшего процветания, фонтанирующей удачи и мирной жизни. С днем защитников и настоящих мужчин!

\section{$* * *$}

Сегодня 23 февраля - день смелых, сильных, решительных, мужественных, стойких и выносливых мужчин, всегда готовых защищать свою родину, свою семью, своих друзей и близких от врагов и неприятностей. Нам повезло, что в нашем коллективе работают именно такие мужчины.

Желаю вам, чтобы вы легко справлялись с любыми проблемами, а женщины ценили и любили вас не только 23 февраля, а каждый день.

\section{$* * *$}

Сегодня, 23 февраля, необычный день. Ведь это самый мужественный день в году. По этому поводу от всей души поздравляю вас с Днем защитника Отечества. Желаю крепкого здоровья, всегда сопровождающей удачи, оптимизма в каждом дне и много сил, чтобы защищать близких от всех жизненных ненастий. 
Поздравляя с Днем защитника Отечества, хочу искренне пожелать, чтобы 23 февраля в вашей семье было одним из самых любимых праздников, чтобы песни звучали всегда в этот день, чтобы добрые слова были вашими спутниками, а любовь не покидала ваш дом. Чтобы небо было ясным, а дожди - благодатными, ну а детский смех никогда не умолкал рядом с вами.

$* * *$

Примите поздравления с 23 февраля с самыми искренними и добрыми пожеланиями удачи, уверенности и мужества. Пусть ваши ожидания хорошего всегда сбываются, а сомнения рассеиваются, как туман в лучах солнца, пусть ваши мечты не заканчиваются, а становятся все ярче и насыщенней, а любовь живет в сердцах верная и взаимная.

$* * *$

Поздравляю с Днем защитника Отечества!

Сегодня в вашу честь будет греметь салют, и я желаю, чтобы у вас было так много счастливых дней, как много в нем разноцветных искр!

Желаю вам крепости духа, мужества и стойкости, побед на всех фронтах: как на работе, так и в повседневной жизни. Пусть дома вас всегда ждут, здоровье всегда будет крепким, а вы всегда активны и энергичны.

$* * *$

Поздравляю с Днем защитника Отечества!

Хочу пожелать настоящим мужчинам нашего коллектива сил, терпения, удачи и добра! Пусть в вашем доме всегда будет мир и покой. Пусть ваши родные всегда будут под вашей 
непробиваемой защитой! Желаю, чтобы в вашей семье подрастало побольше достойных защитников Родины, и чтобы они всегда смогли брать с вас пример храбрости, отваги и справедливости!

$* * *$

Те, кто прошел военные действия, - особенно трепетно относятся к празднику 23 февраля... Эти люди заслуженно отмечают свой праздник - День защитника Отечества. И это не пустые слова, они действительно защищали Родину, мирную жизнь наших детей, давали присягу служить верно и преданно. Но и в обычной жизни Настоящего мужчину отличают мужество, сила воли, умение сдерживать данные обещания. Ведь каждый день мужчинам приходиться оберегать свой маленький мир - свою семью! Быть главой семьи, опорой и поддержкой своим любимым.

Примите искренние поздравления с 23 февраля. Желаю всегда оставаться сильным, смелым, мужественным и энергичным. Пусть здоровье будет крепким, счастье - безмерным, тревоги будут только учебными, а успехи - очень высокими!

$* * *$

23 февраля - праздник чести, смелости, мужества и отваги. Именно эти лучшие мужские качества собраны в Вашем лице.

Позвольте сказать Вам большое спасибо за добросовестный труд и поддержку, которую Вы дарите всему коллективу. Желаю Вам постичь горизонты (указать) дела, не знать страха перед риском и стать настоящим лидером, который направит работу своего подразделения в нужное русло. Пускай откроются двери новых возможностей. А Вы оставайтесь не только отличным руководителем, но и настоящим защитником.

С праздником! 


\section{Mapт}

\section{Международный женский день / 8 марта}

Почему за женщин мы пьем стоя?

Во-первых, потому что лежа пить неудобно.

Во-вторых, чтобы некоторое время гордо возвышаться над ними.

B-третьих, мы пьем стоя, потому что так больше входит.

В-четвертых, мы таким образом разминаем затекшие конечности. В-пятых, мы встаем, чтобы отряхнуть с брюк остатки салата.

В-шестых, встаем для того, чтобы лучше разглядеть всех присутствующих за столом женщин.

В-седьмых, придумали этот ритуал для того, чтобы в случае чего резко рвануть с высокого старта.

В-восьмых, мы таким образом выясняем, кто из нас остался под столом приставать к женщинам.

В-девятых, мы встаем, чтобы потом, садясь, почувствовать облегчение.

И, наконец, мы поднимаемся для того, чтобы не слышать в самое ухо: «Хватит пить! Тебе уже хватит!»

Итак, за женщин! Мужчины пьют стоя!

\section{$* * *$}

Есть такая старинная индийская притча:

«Дочь пожаловалась матери, что она давно влюблена в парня, а он не отвечает ей взаимностью. И мать сказала:

- Это дело поправимое. Принеси мне три волоска, но не обычные, а вырви их из тигриных усов.

- Что ты, мама! - испугалась дочка.

- А ты попробуй, ты женщина, все должна уметь! 
Задумалась дочка. Потом зарезала барана и с куском мяса ушла в лес. Ждет. На запах бараньего мяса появился тигр, разъяренный, кинулся к девушке. Она бросила мясо и убежала.

На другой день она снова пришла, и снова тигр кинулся на нее. Девушка бросила мясо, но не убежала, а смотрела, как он ест.

Так было и в третий, и четвертый раз. На пятый день, увидев еe с мясом, тигр радостно забил хвостом. И женщина прямо с руки стала кормить его. Так было и в следующий раз.

В девятый раз тигр, съев кусок баранины, положил голову на колени девушке.

Блаженно задремал тигр, а девушка выдернула три волосины из тигриных усов и принесла матери домой.

- Ну вот, - сказала ей мать, - ты укротила такого хищного зверя, как тигр. Теперь иди к своему парню и укроти его... Или хитростью, или лаской, или терпением - как сумеешь».

В этой притче отражена вся суть женщины - стремление укрощать заботой и любовью, а не силой. Наши дорогие, любимые женщины, вы - воплощение заботы, справедливости и милосердия, олицетворение тепла и уюта, источник вдохновения и красоты. Вы укрощаете нас своей нежностью и любовью, и мы боготворим вас. Благодаря вашему бесконечному терпению и мудрости нам удается преодолевать все потрясения и невзгоды. Мы очень ценим вас, ваш труд, вашу ежедневную заботу о нас! Вы украшаете нашу жизнь своими очаровательными улыбками, своим оптимизмом и верой в нас! Спасибо вам!

Пусть в этот прекрасный праздник, 8 марта, вас освещают первые весенние лучи и скромное чириканье птиц услаждает ваш слух, и этот день принесет вам только радость и весеннее настроение! Хочется, чтобы каждая женщина ощутила романтику 
сегодняшнего дня, его яркость и обаяние. Милые дамы, будьте удивительно счастливы и открыты для новых, прекрасных горизонтов!

$* * *$

Милые дамы!

Я поздравляю вас с праздником весны, с праздником женской красоты, которая сегодня расцветает в нашем (указать). В моем сердце - самые нежные чувства к вам.

Я думаю, это замечательная традиция с пробуждением весны отмечать этот прекрасный праздник, выражать свои самые лучшие, светлые и сокровенные чувства к женщинам как к чудесному творению природы.

В этот весенний день хочу выразить вам слова восхищения и любви, признательности и благодарности! Все, что мы делаем в жизни, мы делаем для вас, потому что вы даете нам жизнь, любовь и вдохновение!

Пусть начало весны принесет вам радость и удачу, множество сюрпризов. Пусть 8 Марта подарит вам как можно больше улыбок и цветов, наполнит ваши сердца любовью.

Я искренне желаю, чтобы мужчины, которые вас окружают, были настоящими рыцарями, и рядом с ними вы чувствовали себя нежными, хрупкими и защищенными.

А мы, мужчины, сделаем все от нас зависящее, чтобы этот прекрасный праздник продолжался для вас всю жизнь.

Милые дамы! Традиционно 7 марта мне оказывается честь первому поздравить вас с 8 марта, ведь поздравления и подарки от Ваших любимых, я думаю, вы получите только завтра. 
К сожалению, первые дни весны в нашем климате часто бывают серыми и промозглыми, что, конечно, не способствует созданию атмосферы праздника.

К тому же 8 марта принято относить к так называемым гендерным праздникам, так же как 14 и 23 февраля, и многие мужчины зачастую формально подходят к его празднованию. Вообще роковая троица - День всех влюбленных, День защитника Отечества и Международный женский день - может морально и материально выбить из колеи кого угодно. Сначала розы и сердечки, потом водка и галстуки, а в качестве «контрольного в голову» - тюльпаны и духи.

Однако мы, мужчины (указать), - настоящие волшебники, и даже 7 марта, накануне тройного апокалипсиса зимних праздников готовы побороться со стереотипами и сделаем это красиво. Своими руками мы приготовили оригинальные подарки для вас. Получив их, я думаю, вы почувствуете теплоту наших сердец.

(Имена) - чарующие звуки ваших имен радуют меня каждый день, и я этому безумно рад. Каждая из вас обладает своими уникальными достоинствами, благодаря которым наш коллектив можно сравнить с превосходным коктейлем, название которого (указать).

Итак, дорогие дамы, думаю, пора завершать выступление и переходить к подаркам и угощению.

Хочу пожелать вам действительно отдохнуть в эти выходные и порадоваться приближающейся весне. Желаю вам здоровья, как можно больше поводов для радости, счастливых перемен в жизни и, конечно же, любви! Всем, кто еще не нашел свою половинку, желаю скорее ее найти, а тем, кто нашел, его обнять, поцеловать и никому не отдавать! 
Милые дамы!

Казань - это место, где Запад встречается с Востоком. Наша республика славится красавицами разных национальностей. Всем известно, что существуют этнические стереотипы в восприятии женщин разных культур.

Так, татарка красива, носит платок на голове, у нее черная коса, темные брови. В ряду азиатских женщин с незаурядными кулинарными способностями особое место отводится татаркам в повседневном общении они известны своей вкусной едой, мягким тестом, беляшами, эчпочмаками, печеньем.

Она хорошая жена, заботливая, скромная и темпераментная, спокойная, но шустрая. Она эмансипированная интеллектуалка, умная и энергичная, деловая и талантливая.

Внешний облик русской женщины относится к распространенному образу настоящей красавицы - пшеничные волосы, толстая коса, бездонные голубые глаза. В целом это ненавязчивая и естественная красота.

Единодушно признаются доброта и теплота русской женщины как признаки ее любви, терпимости, отзывчивости, душевности, одним словом, той уютности, которая нравится западным мужчинам, поскольку русская женщина - прекрасная хозяйка и мать.

Высокая миссия женщины едина вне зависимости от ее национальности - родить ребенка, обустроить уютный дом, наполнить его добром и любовью - все это испокон веков было женским делом. Семья, материнство, детство - ценности, вокруг которых вращается сама жизнь.

Дорогие женщины, примите самые искренние и теплые поздравления с Днем 8 марта! 
Желаем счастья, нежности, очарования, комплиментов, ежедневных признаний в любви к вам, улыбок и ярких букетов, вечной красоты и молодости, исполнения всех ваших надежд и ожиданий, благополучия вашим родным и близким!

$$
* * *
$$

Дорогие женщины!

От всей души примите поздравления с Международным женским днем - 8 Марта!

В этот весенний день мы, мужчины, выражаем вам благодарность за вашу любовь, заботу и поддержку. Благодаря вашему бесконечному терпению и мудрости нам удается преодолевать все потрясения и невзгоды.

Вы воспитываете детей, сохраняете культурные и духовные ценности, благополучие в семье.

Милые женщины! Желаю вам здоровья, счастья, мира и благоденствия. Пусть каждый день вас окружает забота и тепло близких.

\section{$* * *$}

Примите мои самые теплые и искренние поздравления с Международным женским днем. 8 марта - один из немногих праздников, который не оставляет равнодушным ни одного мужчину.

Все мы - мужчины - готовимся к нему и с волнением ждем его наступления как едва ли не самого главного дня в году. Этот день по особому светел и согрет нашей любовью к вам, нашим преклонением перед вами - нашими мамами, женами, сестрами, дочерьми, хранительницами домашнего очага, мира и лада в семье. Рядом с женщиной любой мужчина стремится быть сильнее, мужественнее и благороднее. 
Мир устроен так, что по большому счету женщина счастлива прежде всего в своей семье, когда здоровы дети, когда в доме достаток и согласие. Пусть будет как можно больше счастливых семей, а значит - и счастливых женщин!

С праздником вас, любимые женщины! Счастья вам, любви, красоты и молодости, исполнения всех ваших надежд, благополучия вашим родным и близким!

\section{$* * *$}

Поздравляю с праздником Весны!

В этот прекрасный день красоты и женственности желаю вам счастья и любви, которые согреют вас в самые крепкие морозы, а летом сделают жизнь ярче!

Желаю нежности и теплоты, весны в душе и праздника в жизни!

$$
\text { *** }
$$

От всего сердца поздравляю с прекрасным весенним праздником - Международным женским днем!

Пусть этот день будет ярким от подаренных вам цветов и светлым от ваших улыбок!

Желаю прекрасного здоровья, душевного равновесия, исполнения всех желаний и профессиональных успехов!

***

С праздником вас, с наступившей весной, наши милые, любимые, дорогие женщины! 8 марта - самый красивый, самый нежный и трогательный праздник, ведь женщина дарит миру веру, надежду, любовь и лучезарные улыбки.

Желаю вам добрых перемен в жизни. Пусть в ваших семьях царят мир, уют и покой! 
Главное качество женщины - женственность. Это внутренний настрой на мир, на гармонию с окружающими. Он подразумевает какую-то тонкость восприятия, нежность. Но женственность вовсе не означает слабость. Женщины, окружающие нас, красивы, умны, обаятельны, профессиональны. Хотелось бы пожелать вам, чтобы весной у вас началась новая, более лучшая жизнь, чтобы все начатые дела завершались удачно и все в вашей жизни расцветало.

\section{$* * *$}

Пусть каждый день будет наполнен теплом и солнечным светом независимо от прогноза погоды. Пусть любовь окрасит Вашу жизнь в яркую гамму чудесных эмоций!

Пусть ваши сердца будут открыты весне, пусть свет ваших глаз и нежность рук дарят миру самое прекрасное!

Пусть рядом с вами всегда будут достойные мужчины! Счастья вам, любви, моря цветов и улыбок!

В этот весенний день желаю вам новых и счастливых поворотов в судьбе!

Я искренне желаю, чтобы мужчины, которые вас окружают, были настоящими рыцарями и рядом с ними вы чувствовали себя нежными, хрупкими и защищенными!

В качестве подарка на 8 марта желаю вам получить бриллиантовое колье, которое тщательно упаковано в норковую шубу, спрятанную в багажнике лимузина с молодым красавцемшофером в придачу! 
От всей души поздравляю вас с 8 Марта! Пусть все цветы мира в этот день лягут к вашим ногам, солнце в вашей жизни никогда не тускнеет, а забота близких всегда согревает своим теплом.

Желаю всегда быть в отличном настроении, украшать своим присутствием нашу жизнь! Будьте всегда счастливы, довольны, успешны, а главное - любимы! Огромных успехов вам на работе и любви, преданности дома!

\section{$* * *$}

Весна - это время любви, новой жизни, самых прекрасных цветов, и неслучайно именно 8 марта, в начале весны, мы поздравляем женщин, ведь они воплощают в себе самые чудесные весенние качества: солнечную улыбку, непредсказуемую весеннюю грозу, нежность и свежесть первой листвы...

Я искренне восхищаюсь вашим жизнелюбием и истинной женственностью и от всей души поздравляю с Международным женским днем! Пусть в вашей жизни будет вечная весна, ярко светит солнце, поют птицы, дни будут светлыми и безоблачными, а бабочки в животе порхают от любви каждый день! Улыбок, хорошего настроения, радости, счастья!

\section{$* * *$}

С радостью поздравляю Вас с Международным женским днем и желаю выразить свое восхищение! Женская душа загадка, в ней столько силы и слабости, любви и стойкости.

Вы замечательный профессионал, знаток своего дела и обаятельная женщина, которая покоряет своей привлекательностью и шармом всех вокруг. 
Желаю Вам семейного и финансового благополучия, успеха во всех сферах жизни. Пусть в этот день и всегда Ваша жизнь будет наполнена радостью, весна всегда будет в душе, а в животе порхают бабочки от любви!

\section{$* * *$}

В Международный женский день, 8 марта, я поздравляю Вас с праздником и от всей души желаю Вам волшебной любви, уюта в доме, исполнения заветных желаний и неувядающей красоты!

Будьте прекрасной женщиной, пусть в Вашем сердце цветет весна, а солнце и звезды обретают отражение в Ваших глазах!

\section{Апрель}

\section{День смеха / 1 апреля}

Поздравляю с Днем смеха! Желаю море улыбок, великолепного настроения, беспрерывный поток положительных эмоций, прекрасного чувства юмора и позитива во всех делах! Смех продлевает жизнь, так давайте жить вечно!

$* * *$

Поздравляю с Днем смеха и хочу пожелать, чтобы жизнь была наполнена добрыми шутками и веселыми затеями, увлекательными интересами и хорошими друзьями, искренними улыбками и настоящим смехом, который обеспечит долгую и счастливую жизнь.

\section{$* * *$}

Поздравляю с Днем смеха, с праздником доброго веселья и хороших шуток. Желаю, чтобы в течение всей жизни юмор и улыбка всегда были с тобой, чтобы искренний смех наполнял 
душу вдохновением и укреплял здоровье, чтобы рядом всегда была надежная поддержка жизнерадостных друзей и близких людей.

$* * *$

Как правильно, что среди праздников есть один, посвященный смеху! Смейся на здоровье, воспринимая с юмором все сюрпризы судьбы. Смейся с друзьями и родными, дари им отличное настроение, будь душой компании и первым фантазером. Пусть День смеха принесет множество приятных моментов и ярких воспоминаний!

\section{Май}

\section{Праздник весны и труда / 1 мая}

Какая же на улице замечательная погода, так и хочется все бросить и отправиться на прогулку. А знаете, что самое интересное, - то, что даже не стоит ничего бросать, потому что сегодня у нас не просто выходной, а самый настоящий праздничный день. У нас сегодня первое мая на календаре, а значит, что наступил День весны и труда. Я хочу поздравить вас с этим праздником, который дает нам несколько лишних выходных дней, в течение которых мы можем отдохнуть и расслабиться. Я предлагаю вам отправиться за город вместе со своими родными, чтобы в отличной компании провести весело время. Желаю вам удачного времяпрепровождения и просто всего самого крутого. Сегодня вы можете забыть о своей работе, потому что этот день предполагает отдых и расслабление. За город сегодня, наверняка, погода еще лучше, так что не упустите возможность. Удачи! 
Какой у нас сегодня день! Конечно же, наступил один из самых любимых и долгожданных праздников, который дает нам несколько лишних выходных дней. Я хочу поздравить вас с Первомаем! Сегодня у нас День весны и труда, однако трудиться совершенно не стоит, потому что у нас выходные. В этот замечательный праздничный день я хочу посоветовать вам собрать всех своих близких и родных, а после этого поехать куда-нибудь на отдых. Вы можете провести несколько дней в веселой компании, не думая о работе, о делах и проблемах. Проведите этот день с максимальной пользой для себя и своих родных. С праздником!

$* * *$

Я хочу поздравить вас с прекрасным праздничным днем, который мы все из года в год с большим нетерпением ждем, потому что именно этот замечательный праздничный день дарит нам несколько выходных. Я поздравляю вас с Первомаем! Проведите этот День весны и труда с большой пользой для себя, соберите веселую компанию из своих друзей и близких, а затем отправляйтесь на активный отдых. Можете, конечно, выбрать и пассивный отдых, потому что он тоже бывает полезным. После долгих рабочих месяцев любой отдых будет вам на пользу. Я поздравляю вас с тем, что наступила долгожданная весна. Конечно, она наступила еще пару месяцев назад, однако именно с сегодняшнего дня нас ожидают теплые денечки. С праздником весны и труда вас!

$$
* * *
$$

Ну вот и наступил долгожданный праздничный день, который мы все ждем с таким нетерпением, что многие даже и представить не могут. После долгих рабочих месяцев так и хочется 
немного отдохнуть и перевести дух на природе. Так что я вам желаю хорошего настроения на все эти выходные дни, а после этого пусть ваше настроение будет держаться на высоте. До лета совсем немного времени, поэтому работать осталось не так долго. Желаю вам веселого и счастливого времяпрепровождения со своими родными и близкими людьми. Наберитесь максимальной пользы для себя. Получите массу положительных эмоций и позитивного заряда энергии. Пусть этот праздничный день будет насыщен яркими и интересными событиями. Первомай является тем праздником, который располагает к хорошо проведенному времени и замечательному настроению. Удачи!

$* * *$

Посмотрите, какая замечательная солнечная погода на улице! Так и хочется просто оставить все свои дела и пойти на прогулку в ближайший парк. Однако на сегодня у вас будет самая лучшая развлекательная программа, потому что сегодняшний праздник не время для дел и проблем. Праздник весны и труда бывает лишь один раз в году, однако длится он несколько дней. Поэтому у вас есть возможность хорошенько отдохнуть и расслабиться в отличной компании. Я поздравляю вас с Первомаем! Если вы не знаете, как провести этот день, то я хочу предложить вам один замечательный способ. Просто соберите своих друзей, накупите продуктов и отправляйтесь за город на пикник. Согласитесь, что это будет отличным способом развлечься и отдохнуть, а еще набраться сил и энергии. Удачного вам времяпрепровождения! С Первомаем вас! Удачного дня!

\section{$* * *$}

Как же мы все ждали этот замечательный праздничный день, потому что он дает нам возможность отдохнуть и развлечься в 
компании своих друзей и родственников, которых мы в обычное время практически не видим. Этот прекрасный праздничный день под названием Праздник весны и труда дарит нам из года в год несколько выходных дней, поэтому нельзя упускать их, а надо проводить с максимальной пользой для себя. Я хочу пожелать вам хорошего настроения, потому что без него просто никуда. С Первомаем вас! Пусть этот праздник подарит вам массу положительных эмоций и позитивной энергии. Заряжайтесь позитивом, потому что в такой замечательный праздничный день он витает даже в воздухе. Обзвоните сейчас же всех своих друзей, с которыми вам приятно проводить время. Отправляйтесь на прогулку или поезжайте за город, на природу. С Праздником весны и труда вас!

\section{***}

Помните ли вы о том, какой сегодня день? Я думаю, что нет ни одного человека, который не знает, что сегодня за день, потому что Первое мая ждут все из года в год с большим нетерпением. Я хочу поздравить вас с этим замечательным днем - Праздником весны и труда. Несмотря на то, что весна уже пару месяцев как наступила, именно с сегодняшнего дня начинается период отличной погоды. Проведите этот день вместе со своими друзьями и родными, которых вы так сильно любите. На природе сегодня точно будет весело, так что можете отправиться именно за город. Удачного вам дня!

\section{День Победы в ВОВ 1941-1945 / 9 мая}

Разрешите поздравить вас с великим праздником. С Победой над фашизмом!

Огромную невероятную цену заплатил наш народ за Победу над фашизмом, и лично вы вписали свою страницу в летопись 
боевой славы всей страны. Пережив страшные невзгоды, сохранили веру в победу над врагом. Это беспримерный подвиг служения Отчизне!

Трудно выразить словами благодарность, которую я испытываю к вам и нашим ветеранам, отстоявшим мир и покой на земле. К сожалению, с каждым днем их становится все меньше и меньше. Мы в неоплатном долгу перед ними.

Постоянно помнить о завоеванной свободе и независимости, крепить свое единство, достойно жить и работать - наша святая обязанность.

От всей души поздравляю вас с праздником Великой Победы. Счастья, радости, мира и благополучия каждой семье, каждому дому!

\author{
$* * *$ \\ Вы все в памяти нашей, ветераны войны... \\ Той далеко и сильной... Той советской страны... \\ Тихо голову склоним... Просто все мы помолчим... \\ За Победу спасибо вам, любимым и родным...
}

Мы гордимся и всегда будем гордиться Великой Победой в Великой Войне. Величие Победы выражается и в том, что значение ее растет с каждым годом. Этот день навсегда останется одним из самых торжественных, значимых и счастливых для всех нас. Мы никогда не забудем славный подвиг нашего могучего и сильного духом народа, сплотившегося в тяжелое и страшное для всей страны время и отстоявшего свою Родину.

Прошло уже ... лет, как закончилась Великая Отечественная война. Но память о ней не меркнет, передается от поколения к поколению, от родителей к детям, от сердца к сердцу. И главной 
силой такого родства является любовь к России, к родному дому, к своим близким, к своей семье!!!

С праздником Вас! Здоровья, новых сил, любви и свершений!!!

$$
* * *
$$

КЛЯТВА

И та, что сегодня прощается с милым, -

Пусть боль свою в силу она переплавит.

Мы детям клянемся, клянемся могилам, Что нас покориться никто не заставит! Июль 1941, Ленинград

9 мая 1945 года - эта дата навечно вписана в историю нашей страны. В героической летописи Российского государства не было битвы более жестокой, чем Великая Отечественная война. Не было подвига значительнее, чем подвиг советского солдата, защитившего родину от врага, спасшего мир от нацизма.

Наш народ, как никто другой, знает цену миру и превыше всего ставит честь и свободу своей Отчизны. Мы храним в сердцах не только мужество, героизм, отвагу воинов и тружеников тыла, но и горечь утрат военного лихолетья. Миллионы людей навсегда остались на полях жесточайших сражений, приближая счастливый день всенародного торжества и славы - День Великой Победы!!!

Искренне желаю мира, добра, счастья вам и вашим родным и близким! С Днем Победы! 


\section{Последний звонок / 25 мая}

Сердечно поздравляю вас со знаменательным, ярким и торжественным событием! Этот день не отмечен ни в одном календаре, однако это важная дата для вас, трогательный день для ваших педагогов и родителей, которые помнят вас малышами-первоклассниками.

Последний звонок открыл для вас новый, безумно интересный этап жизни. С этого момента вы несете ответственность за свою свободу в мыслях и действиях.

Я думаю, что большинство выпускников уже решили, в какой профессиональной области реализоваться, чтобы быть полезным своей стране, своему государству.

Вы получили огромный массив знаний, которые составляют прочный фундамент вашего дальнейшего обучения в вузах.

Слова бесконечной благодарности я адресую педагогическому составу школы, профессиональному и компетентному, который воспитал этих талантливых молодых людей, научил их творчески мыслить, и родителям, воспитавшим таких прекрасных ребят.

Дорогие выпускники, желаю вам поступления в самые престижные вузы и реализации самых смелых планов!

$* * *$

Мне хочется от всей души поздравить наших будущих выпускников, которых до взрослой жизни отделяет всего несколько шажочков. Сегодня важный день для любого из вас, хотя, возможно, что вы даже до конца и не понимаете, что происходит. У вас уже были подобные последние звонки в четвертом классе и в девятом, однако это совершенно не то. Только представьте, что первого сентября этого года вы придете уже не в школу, а в свои 
новые учебные заведения. Кого-то эта новость явно порадует, а вот кого-то, наоборот, огорчит. Но поверьте, что через какое-то время вы все немного взгрустнете, потому что захотите вернуть школьные годы. Так что пока у вас есть еще несколько дней наслаждайтесь ими. И не переживайте по поводу экзаменов, потому что вы можете все. Вы все сдадите и получите самые высокие баллы, мои дорогие выпускники! Удачи вам!

\section{$* * *$}

Еще недавно вы только впервые пришли в школу, у вас была первая линейка, а еще был первый урок. Помните, какими радостными, но в то же время и взволнованными вы были в тот момент? Вы купили самые красивые портфели, пеналы и тетради, которыми так гордились. Вы почувствовали себя взрослыми и даже немного самостоятельными, а вот сегодня вы уже совсем взрослые - самые настоящие выпускники. Мне хочется от всей души поздравить вас с этим замечательным событием в вашей жизни - с Последним звонком. Я знаю, как долго вы готовились к этому дню, поэтому даже не сомневаюсь, что у вас все получится. C праздником вас, мои самые дорогие выпускники! Мне хочется вас всегда видеть такими вот счастливыми, как сейчас. Пусть все ваши мечты и желания исполнятся, а идеи и планы реализуются. Вы всегда можете рассчитывать на нашу поддержку, ребята.

\section{$* * *$}

Мне хочется от всей души поздравить вас, мои самые дорогие ребята, мои выпускники. Вы проделали долгий путь, который был не всегда легким, но вы выдержали. Я хочу поздравить вас и сказать, что вы большие молодцы. Вы не просто выпускники, вы уже совсем взрослые люди, которые прошли через один важный 
этап в своей жизни. Мне хочется пожелать каждому из вас терпения и стойкости, а еще выдержки и много сил, потому что не все будет даваться вам с легкостью, но поверьте, что вы можете справиться с любой проблемой, потому что вы уже прошли одну школу жизни. Но сегодня забудьте обо всем, потому что в этот замечательный праздничный день вы должны отдыхать и развлекаться. Сегодня только лишь ваш день, а экзамены немного потерпят. С праздником вас, ребятки мои! Пусть этот день подарит каждому из вас массу положительных эмоций.

$* * *$

Мне хочется поздравить этих замечательных ребят, которые стоят сейчас передо мной, с праздником! У вас сегодня Последний звонок - день, который вы так долго ждали. Многие из вас вообще ждали этот день с момента поступления в школу. Дорогие мои, вы выдержали невероятную школу жизни, ведь здесь вы не просто учились, но и влюблялись, дружили, ссорились и мирились. Вы стали настоящими личностями со своими неповторимыми качествами. Мне хочется, чтобы так было и дальше, потому что вы действительно можете добиться небывалых высот. Мне хочется, чтобы каждый из вас добился того, о чем давно мечтает. Пусть этот праздничный день еще больше укрепит вашу дружбу. Я надеюсь, что вы и дальше будете поддерживать хорошие и сплоченные отношения друг с другом. С праздником вас!

Наступил тот день, о котором вы мечтали уже последние несколько лет. На самом деле, это нормально, хотя и немного неправильно. Вы все спешите взрослеть и не живете настоящим днем. Мне не хочется, чтобы вы потом пожалели об этом, поэто- 
му хочу предостеречь вас. Я хочу поздравить вас, мои дорогие ребята, с праздником, ведь у вас сегодня Последний звонок. Сейчас вы все передо мной стоите такие веселые и счастливые ребята в красивой школьной форме, а ведь еще недавно вы только пошли в первый класс. Хочу пожелать каждому из вас исполнения всех самых заветных желаний. Вы все ребята способные и ответственные, поэтому я даже не сомневаюсь, что вы добьетесь всех самых значительных результатов. Пусть каждый ваш день будет полон красивых событий, приятных мгновений и всего самого положительного. Получайте удовольствие от этого дня, ведь он больше не повторится.

\section{Июнь}

\section{Международный день защиты детей / 1 июня}

Период детства является наиважнейшим в жизни. Это самый первый этап, который включает в себя первичную социализацию маленького человека, вступающего на большой путь. И от того, каким будет детство, зависит траектория будущего развития личности. Именно поэтому необходимо уделять этому нежному времени особое внимание, защищать и оберегать детей.

В этот прекрасный праздник я хочу от всей души поблагодарить вас за вашу работу, за всю доброту и тепло, которое вы дарите детям. Пусть ваше дело приносит вам радость.

\section{$* * *$}

Дети - это украшение нашего сурового и порой опасного мира. Без них жизнь общества оказалась бы в черно-белых красках. Нужно заботиться и защищать деток, у которых еще есть шанс для того, чтобы изменить окружающий мир, существующую 
жизнь в самую лучшую сторону. Малыши так наивно верят в светлость и красоту всех мгновений бытия, чувствуют только весну в своей душе, и в их глазах можно прочитать искренность.

Все это умиляет взрослых людей, повидавших на своем жизненном пути много разных испытаний и понимающих, что на самом деле не все так просто, как хотелось бы. День защиты детей - это возможность сделать шаг навстречу друг другу, подарить море позитивных эмоций и огромную веру в то, что в жизни все обязательно будет складываться так, как хотелось бы. Хочется пожелать здоровья и счастья деткам, ведь именно они должны менять мир в лучшую сторону прямо сейчас.

\section{День социального работника / 8 июня}

Сегодня в День социального работника я от всей души хочу поблагодарить вас за ваш самоотверженный труд, за милосердие и сопереживание, за ваш опыт и профессионализм.

Работник социальной сферы - это призвание! Выполнение ваших должностных обязанностей требует не только времени и знаний, но и душевной энергии, тепла и сострадания.

Желаю вам не растерять той доброты, которой наполнено ваше сердце, не утратить веры в людей и чтобы друзья и близкие поддерживали ваше призвание, помогали и заботились о вас. Пусть ваш дом всегда будет полной чашей и искорки оптимизма никогда не угаснут в вашей душе.

\section{$* * *$}

Поздравляем вас с профессиональным праздником!

День социального работника - этот профессиональный праздник сравнительно молод, но не время определяет его значимость, а ваша важнейшая общественная миссия. Ваша деятель- 
ность является главным звеном в осуществлении государственной социальной политики. А потому ваш ответственный труд это служение по призванию.

От результатов такого труда зависят стабильность в обществе, благополучие граждан и вера в социальную поддержку.

Спасибо вам за ваш благородный труд, терпение и ответственность! Желаем крепкого здоровья, оптимизма, отличного настроения и благополучия вам и вашим близким!

Мы верим, что и впредь нашу трудовую деятельность будет отличать высокая планка качества работы, креативность, стремление чутко реагировать на инновации регионального и федерального масштаба, а груз огромной ответственности будет облегчаться благодарностью людей за проявленную о них заботу!

8 июня мы отмечаем День социального работника. Этот праздник посвящен людям, чья профессия требует не только добросовестного отношения к делу, но и благородства души, огромного терпения, умения сопереживать.

В нашем городе приняты и реализуются немало социальных программ. Но все принятые программы и планы не имеют никакого смысла без людей, которые их выполняют, в том числе и без нас. Мы имеем серьезные перспективы и желание повысить уровень социальной защищенности населения региона. Я уверен, что все наши глобальные проекты будут осуществлены благодаря профессионализму и ответственности каждого из нас! В связи с этим предлагаю выпить за здоровье присутствующих. 
Я рад, что имею возможность поздравить вас с профессиональным праздником - Днем социального работника!

Люди, работающие в сфере социального обеспечения, должны иметь особый характер, они выбирают эту специальность по зову сердца и души.

Мы с вами внесли большой вклад в развитие социальной системы России. С каждым годом растет профессионализм наших сотрудников, наши ряды пополняются грамотными специалистами, владеющими современными знаниями.

Желаю вам новых успехов, плодотворной работы, счастья, благополучия, здоровья вам и вашим близким! С Днем социального работника!

\section{День России / 12 июня}

Я хочу поздравить вас с одним из самых почитаемых и особенных праздников, который играет большую роль в жизни нашей страны. Речь идет о Дне России, который мы ежегодно отмечаем двенадцатого июня. Мне хочется пожелать вам хорошего настроения и как можно больше сил, потому что вас ждет огромное количество интересных мероприятий, в которых непременно нужно принять участие. Поверьте, что для нас, для граждан, этот праздник имеет большое значение. Мы должны уважать этот день, потому что он напрямую связан с нашей любимой Родиной. Это невероятная честь - быть частью такой великой державы, представлять ее за границей. Именно поэтому нам непременно нужно быть внимательными, потому что на наших плечах лежит груз ответственности. Ну а сегодня мы должны хорошенько повеселиться, отдохнуть и отметить день, посвященный нашей Родине. 
$* * *$

Мне хочется поздравить вас с этим прекрасным праздником, который уже с самого утра празднуется в нашей стране. В каждом городе проводятся различные мероприятия, посвященные Дню России. Именно этот праздник мы ежедневно отмечаем в нашей стране двенадцатого июня. Я хочу поздравить вас с этим прекрасным событием, а также пожелать всего самого позитивного и положительного. Быть гражданином такой великой страны, великой державы - это настоящая честь и гордость. Мне хочется, чтобы вы всегда с гордостью и восхищением говорили о своей родине, о своей стране. Мне хочется пожелать вам хорошего настроения, потому что без него не возможен ни один день, особенно такой праздничный. Пусть этот день подарит вам массу приятных эмоций и положительной энергии. С Днем России вас! Помните, что наша страна является самой лучшей и самой красивой!

\section{$* * *$}

Ну, вот и наступило лето, а вместе с ним пришли еще и замечательные праздники, которые всегда проходят очень весело и интересно. Мне хочется поздравить вас с Днем России, который отмечают ежегодно двенадцатого июня, то есть сегодня. Самое главное, что хочется сказать в этот день, то, что нет ни одной страны, которая была бы похожа на нашу любимую Россию. У нас самая лучшая страна, которой нет конца и краю. С каждым годом она становится все интереснее для туристов, все лучше для своих граждан и гостей. Мне хочется, чтобы так было всегда. Сейчас уже на нас лежит ответственность за нашу прекрасную страну. Именно поэтому мы не должны подводить, а должны всегда помнить, что именно мы отвечаем за будущее нашей дер- 
жавы. А сегодня у нас есть возможность хорошенько отдохнуть и повеселиться, поучаствовать в различных мероприятиях, которые посвящены этому дню.

$* * *$

Я хочу от всей души поздравить вас с одним очень важным праздничком. Многие люди любят этот день только за то, что он предоставляет нам лишнюю возможность отдохнуть от работы. Однако этот день не зря носит название Дня России, потому что он посвящен нашей любимой стране. Я хочу, чтобы и вы чувствовали, насколько этот праздничный день важен для нас, именно поэтому его всегда отмечают с таким размахом. Мне очень хочется, чтобы вы в этом году приняли участие в праздничных мероприятиях, потому что они организовываются для того, чтобы граждане России, а также гости хорошо провели время и отдохнули. Кроме того, у людей будет возможность узнать как можно больше информации об истории нашей страны и так далее. Я хочу, чтобы вы были сегодня активны и энергичны. Пусть этот день будет насыщен приятными эмоциями и чувствами. Удачного дня вам!

$* * *$

На календаре уже двенадцатое июня, а это означает, что наступил один из самых любимых праздников в нашей стране. Речь идет, конечно, о Дне России! Именно в этот день у людей появляется возможность немного отдохнуть и отвлечься от работы. Мне хочется и вас поздравить с этим замечательным событием, а также пожелать всего того, что способно поднять вам настроение и держать его на высоте в течение всего дня. Я хочу, чтобы вы приняли участие в сегодняшних мероприятиях, 
потому что они проводятся специально для того, чтобы сплотить народ, чтобы дать возможность людям весело провести время. Поверьте, что сейчас это как никогда необходимо, потому что впереди еще несколько недель упорной работы. Я хочу, чтобы вы никогда не забывали, что наша страна является одной из самых лучших, если не самой лучшей. Мы гордимся ею и хотим, чтобы она процветала.

\section{$* * *$}

Наступил наш любимый праздничный день, который из года в год собирает на улицах всех городов людей, которые принимают участие в самых разных мероприятиях. В свою очередь, данные мероприятия организовываются по поводу Дня России. Да, как вы помните, именно двенадцатого июня в нашей стране отмечают этот прекрасный праздник. По-другому и быть не могло, потому что такие замечательные праздники должны проводиться именно в такие солнечные и яркие дни. Мне хочется поздравить вас и пожелать вам самого главного - приподнятого настроения и боевого настроя, потому что именно это необходимо для того, чтобы весело провести этот день, получить максимальное количество пользы. Поверьте, что сегодня вы, наверняка, встретите большое количество своих знакомых, потому что в этот день все будут гулять, веселиться и отдыхать. Удачи!

$* * *$

Я так люблю этот замечательный праздник - День России, потому что он всегда создает неповторимую атмосферу в каждом уголке нашей необъятной родины. Мне хочется поздравить и вас с этим прекрасным событием, а также пожелать всего того, что поспособствует поднятию вашего настроения, потому что такой 
день нужно встречать в приподнятом расположении духа. Никогда не забывайте о том, что вы являетесь представителем этой замечательной страны, поэтому держать имя нашей родины России нужно на самом высоком уровне. Мне хочется, чтобы вы сегодня хорошо провели время в компании своих друзей и близких, потому что в такой день нужно развлекаться и отдыхать. Забудьте о работе, о делах и обо всех проблемах, потому что в праздничный день нужно расслабиться. Желаю вам круто провести время, получить удовольствие, чтобы вечером от усталости сразу заснуть.

\section{$* * *$}

Я хочу поздравить вас с самым замечательным праздником, который у всех ассоциируется в первую очередь с отличным настроением. Мне хочется, чтобы вы сегодня отлично провели время, потому как даже погода к этому располагает. Посмотрите, какая замечательная солнечная погода за окном, ведь так и хочется пойти прогуляться, не так ли? А вот сегодня у вас есть возможность официально и законно прогулять свою работу, чтобы весело провести время со своими друзьями. Кстати, сегодня в городе будут организованы самые разные мероприятия, так что вам нужно набраться сил, чтобы успеть поучаствовать во всех тех, которые вас больше всего заинтересуют. Желаю вам отличного настроения и боевого настроя. Пусть этот праздник подарит вам новые знакомства и приятные эмоции. И помните, что у нас самая лучшая родина.

\section{$* * *$}

Сегодня у нас на календаре уже двенадцатое июня, а это означает, что наступил один из самых любимых праздников День России. Мы все любим нашу родину, ценим все то, что она 
дает нам, делает для нас и ради нас. Однако и мы сами должны отвечать взаимностью, а сделать это можно многими способами. Во-первых, нам нужно всегда высоко держать имя нашей страны, в особенности тогда, когда мы находимся по тем или иным причинам за границей. Я хочу пожелать вам еще больше патриотизма, хотя его у вас и так достаточно. Я знаю, как вы любите нашу родину, которая обладает невероятно богатой и интересной историей. Сегодня вы должны хорошенько отдохнуть, ведь наша страна отмечает свой собственный день. Ради этого, кстати, наши граждане получили лишний выходной день. Пусть этот день станет одним из самых любимых для вас. Удачного вам празднования!

\section{$* * *$}

Мне хочется поздравить вас с Днем России! Этот праздник является одним из самых любимых среди граждан нашей страны, потому что в этот день, как правило, устраиваются самые интересные мероприятия, в которых может принять участие любой желающий. Я очень надеюсь, что вы тоже относитесь к этому числу людей, которые потратят этот выходной на развлечения и отдых. Мне хочется пожелать вам отличного настроения, потому что именно оно поможет нам хорошенько отдохнуть. Пусть этот замечательный праздник подарит вам массу положительных эмоций, позитивной энергии, а также оставит вам множество воспоминаний. А потом именно эти воспоминания будут греть вашу душу. Вот увидите, что этот праздничный день станет одним из самых любимых для вас. Я поздравляю вас с этим праздником и с тем, что и вы являетесь частью этого праздничного дня. 
У нас на календаре уже двенадцатое июня. И это не просто солнечный летний день, а самый настоящий праздник - День России. Мне хочется поздравить вас с этим важным и значительным событием, которое представляет особую ценность для каждого из нас. Мне хочется пожелать вам всегда оставаться патриотом своей страны, поддерживать нашу страну что бы ни случилось. Помните, что нет ничего важнее родины, поэтому нужно всегда уважать и ценить ее. Вот сегодня, например, вы можете это продемонстрировать. Вам нужно будет всего лишь весело и интересно провести этот день. Сегодня будет организовано огромное количество самых разных мероприятий, в которых вы можете принять самое активное участие. Так что запаситесь энергией и действуйте. А еще вы должны будете позвать с собой родных и друзей, чтобы уж точно круто провести время. Удачи!

Как известно, ежегодно двенадцатого июня в нашей стране празднуется особый день - День России. Этот праздник представляет большой интерес для каждого гражданина, поэтому мы должны уважительно относиться к этому дню, чтобы показать, как мы любим нашу родину. Мне хочется пожелать вам приподнятого настроения, боевого настроя и как можно больше позитивных и положительных эмоций и воспоминаний. Я хочу, чтобы вы всегда чувствовали груз ответственности на своих плечах за нашу родину. Именно мы ответственны за будущее нашей страны, так что от нас действительно многое зависит. Я хочу, чтобы вы забыли о работе и просто весело провели время. Принимайте участие в конкурсах, концертах и других мероприятиях, каждый 
из которых представляет собой особый интерес. Удачного вам празднования! Пусть этот день подарит вам новые знакомства.

\section{День медицинского работника / 19 июня}

Поздравляю Вас с профессиональным праздником - Днем медицинского работника!

Профессия медицинского работника является одной из самых важных и уважаемых во всем мире. На представителей вашей профессии возложен груз ответственности, и нести его могут только люди с широкой душой и добрым сердцем. $\mathrm{C}$ самого момента рождения человека и на протяжении всей его жизни вы всегда готовы оказать необходимую помощь, поддержать и восстановить здоровье.

От всей души хочу поблагодарить Вас за этот нелегкий, но жизненно необходимый труд, и пожелать Вам счастья, благополучия и душевного спокойствия!

\section{$* * *$}

Люди, работающие в сфере медицинского обслуживания, должны иметь особый характер, люди выбирают эту специальность по зову сердца и души.

Вы всегда проявляете чуткость, внимание, заботу, уделяете время, ведь зачастую пациенту непросто разобраться в сложных медицинских терминах и назначенных обследованиях.

Я очень ценю предоставленную мне возможность обращаться к Вам за консультацией. Поздравляю с профессиональным праздником! 


\section{День молодежи / 27 июня}

День молодежи - это день чествования школьников, студентов, молодых работников и предпринимателей - главного потенциала нашей страны. Именно молодежь легко ориентируется в современном, быстро изменяющемся мире, поражает своей активностью, смелостью в принятии решений, открывает новые научные горизонты, развивает гражданскую активность и сознательность. В этот день от всей души желаю вам открывать для себя новые возможности для самореализации, хорошего настроения и веры в будущее!

\section{Июль}

\section{День российской почты / 2-е воскресенье июля}

Поздравляю Вас и ваших коллег с этим знаменательным праздником - Днем российской почты!

Ваша работа заслуживает особого внимания и уважения. В любую точку нашей необъятной страны, не смотря на трудности, изо дня в день сотрудники Почты доставляют корреспонденцию, обеспечивая людей информацией. Благодаря вам и вашему делу мы имеем возможность получать письма от близких людей, а это стоит особой признательности.

В этот праздник от всего сердца я желаю Вам счастья, профессиональных успехов и благополучия!

\section{День ГИБДД МВД РФ / 3 июля}

От всей души поздравляю Вас и ваших коллег с профессиональным праздником сотрудников автоинспекции. 
Движение - это жизнь! Сегодня не представляется возможным вообразить улицы наших городов без автомобилей. Координировать взаимодействие пешеходов и водителей ваша работа. Именно сотрудники автоинспекции обеспечивают безопасность на дорогах нашего региона и страны. В любое время суток, не смотря на погодные условия, сотрудники ГИБДД стоят на страже жизни и здоровья граждан.

В этот знаменательный день я хочу поблагодарить Вас за этот сложный, ответственный и необходимый труд и пожелать профессиональных успехов, крепкого здоровья и благополучия.

\section{$* * *$}

Я хочу от всей души поздравить вас с вашим профессиональным праздником - с Днем работника автоинспекции! Мне хочется от всей души пожелать вам всего самого позитивного и положительного, чего вам обычно не хватает на рабочем месте. Вы много сил тратите, когда находитесь на службе, поэтому я хочу пожелать вам крепкого здоровья и больше источников энергии. В этот прекрасный праздничный день мне хочется выразить вам благодарность от лица всех водителей и пешеходов, потому что мы осознаем, что без вашего участия наше передвижение по городу было бы очень опасным и невозможным. Я хочу пожелать вам всего самого прекрасного и светлого, что только есть в этом мире. Пусть этот праздничный день подарит вам множество поводов для радости, потому что вам этого определенно не хватает. Удачного вам дня! С праздником!

$$
* * *
$$

Сегодня просто прекрасный жаркий летний день, благодаря которому вы сможете отлично провести время и отдохнуть в 
приятном обществе своих друзей и близких. Как вы знаете, у вас сегодня, третьего июля, профессиональный праздник. Я хочу от всей души поздравить вас, наши дорогие автоинспекторы, и сказать, что ваша работа имеет очень большое значение для каждого человека, проживающего в нашей стране. Все автолюбители и пешеходы ежедневно благодарят вас за труд, за помощь и за содействие в решении самых различных вопросов и проблем. Вы ежедневно берете на себя большую ответственность. Мы хотим, чтобы вам на пути всегда встречались исключительно благодарные люди, которые будут ценить ваш труд. Я хочу пожелать вам отличного настроения, а также всего того, что поможет вам немного отдохнуть за этот день. Мне хочется, чтобы вы всегда получали удовольствие от своей работы.

\section{***}

В этот прекрасный летний день - третьего июля - я хочу поздравить вас с вашим профессиональным праздником - с Днем ГАИ. Именно в этот день мы можем в очередной раз продемонстрировать то, насколько важной является ваша трудовая деятельность. Мы знаем, как временами вам бывает трудно, потому что не все люди благоприятно и положительно настроены по отношению к вам и к вашей работе. Я хочу пожелать вам крепкого здоровья и удачи! Поверьте, что удача является той составляющей, которая необходима человеку для достижения больших и самых значительных результатов. Мне хочется пожелать вам еще и терпения и стойкости, потому что из-за своей работы вы часто раздражаетесь и нервничаете, а это негативно сказывается на вашем здоровье. Пусть этот прекрасный праздничный день порадует вас хорошей погодой, позитивными пешеходами и автолюбителями. 


\section{Август}

\section{День города}

Всем хорошо известно, что одним из самых любимых и популярных праздников в нашей стране по праву считается День города, в котором мы живем. Согласитесь, что любой город индивидуален по своему - своей историей и культурой, событиями, трудовыми, творческими, спортивными и другими достижениями, простыми, успешными и знаменитыми людьми.

В день проведения праздника Дня города, который пройдет (дата), можно будет увидеть частицу души горожан, их настроение и отношение к самому городу, узнать, как горожане относятся к нему, чем они люди и чем дышит их любимый город. Желаем всем жителям города удачи, радости и веселья!

\section{Сентябрь}

\section{День знаний / 1 сентября}

Сегодня особенный день для моего дорогого школьника, потому что он в очередной раз отправляется на линейку в свою любимую школу.

Мне хочется пожелать тебе отличного настроения, потому что сейчас его тебе реально не хватает. Кроме того, хочу пожелать тебе много положительных отметок, а вот отрицательных пусть будет как можно меньше, потому что в прошлом году их было достаточно.

Я хочу, чтобы ты не переживал по поводу начала нового учебного года, потому что он пролетит так быстро, что ты даже заметить не успеешь. Мне хочется пожелать тебе много новых 
друзей, хотя я даже не сомневаюсь, что к концу этого у тебя будет человек на сто больше друзей.

Мне нравится, что ты умеешь дружить, что умеешь находить общий язык с разными людьми. Но не забывай и про свои уроки, потому что они очень важны. Поверь, что школа играет очень важную роль в жизни человека.

$* * *$

Я хочу поздравить с началом нового учебного года моего любимого школьника.

Не могу поверить в то, что ты стал еще на один год старше, потому что мне казалось, что это время будет так долго тянуться. Но, как ты уже успел заметить, время пролетает с огромной скоростью, а это значит, что и этот год пройдет очень быстро.

Тебе нужно просто научиться получать удовольствие от каждого дня, проведенного в школьных стенах, потому что совсем скоро ты уже окончишь школу. Поверь мне, что потом ты будешь вспоминать эти годы с большой грустью, поэтому просто цени. Я не говорю тебе учиться только на одни пятерки, потому что это невозможно, но старайся разнообразить немного свой дневник.

Я тебе желаю всего самого позитивного, мой дорогой школьник. Собирайся в любимую школу, которая заждалась твоих шуточек и розыгрышей. Счастливого учебного года.

\section{День финансиста / 8 сентября}

Вы лучше всех знаете возникающие проблемы финансовой сферы и успешно их решаете: находите новые источники доходов, сокращаете расходы. Сейчас в наше нелегкое «кризисное» 
время многие люди пересматривают не только свой бюджет, но и свои взгляды. Как, например, в одном анекдоте:

«Разговаривают две подруги:

- Ты знаешь, у меня в последнее время совсем другие требования к мужчинам, главное, чтобы он был добрый, отзывчивый, человечный... Как думаешь, остались еще такие финансисты?»

Так что я поднимаю бокал за добрых, отзывчивых и человечных финансистов, и это только малая часть всех положительных качеств, которыми они обладают!

\section{$* * *$}

Желаю вам успешного преодоления всех жизненных штормов и препятствий, роста клиентской базы, завоеваний новых сегментов на зарубежном финансовом рынке, а также всех удачных свершений и больших достижений в будущем!

Пусть работа приносит вам радость, а ваш профессионализм и опыт всегда позволяют принимать верные и взвешенные решения. Успехов, процветания, стабильности и крепкого здоровья вам и вашим близким!

\section{Октябрь}

\section{Международный день пожилых людей / 1 октября}

Я рад вас всех видеть в зале, таких энергичных, бодрых, полных энтузиазма. По своему жизненному тонусу вы дадите фору многим представителям молодого поколения. Вы открываете в себе новые таланты, продолжаете вести активную общественную жизнь, участвуете в реализации социальных проектов, занимаетесь спортом, участвуете в культурной жизни города, 
щедро делитесь с нами своими знаниями и мудростью. Признаюсь, я вдохновляюсь примером своих старших коллег.

Недавно психологи пришли к удивительному выводу, что чем старше человек, тем чаще он испытывает позитивные чувства. Возможно, дело в том, что возраст способен нас вознаградить опытом и мудростью, сделать наши ожидания более реалистичными и помочь открыть новое в себе и для себя.

Желаю вам надолго сохранить в себе этот позитив, жизнелюбие, оптимизм и тягу к новым впечатлениям!

$$
* * *
$$

Сегодня наступил поистине прекрасный праздник, который обязательно нужно отметить по достоинству. Мы сегодня отмечаем День пожилых людей, проявляя почтенное уважение и стремление отметить, насколько достойной является жизнь в любом ее возрасте. Хочу пожелать идеального здоровья и энергии, любви близких людей, домашнего уюта. Пусть настроение всегда будет позитивным, а вера в лучшее будущее сохраняется навсегда. Желаю, чтобы внуки и дети радовали успехом и достижениями, старались помогать по быту. Ты еще можешь отметить важные достоинства жизни и понять, насколько судьба является благосклонной. Искренне надеюсь, что здоровье будет сохранено идеальным надолго. Пусть пожилой возраст не становится преградой для обретения настоящего счастья и возможности ценить каждый день жизни по достоинству, наслаждаясь всеми мгновениями, минутами.

$$
* * *
$$

Сегодня отмечается поистине прекрасный и достойный праздник - День пожилых людей. Многие жители мира оказались 
сплоченными друг с другом, ведь они стараются позвонить и передать приветы, сказать достойные поздравления друг другу. Пусть подаренное внимание обязательно будет важным фактором для тебя, мой милый человек. Не нужно считать, что жизнь подошла к закату, ведь даже сейчас каждый день может чем-то особенным порадовать и, конечно, дать вдохновение для дальнейшего развития. Искренне желаю много энергии и активности, стремления к успеху и гармонии, возможности посмотреть на прожитые события под новым углом. Пусть рядом с тобой всегда будут близкие люди, которые смогут порадовать и позаботиться. Помни, что крепкая и дружная семья - это наилучший подарок для каждого человека, потому твои дети и внуки заслуживают внимания и заботы.

Сегодня все внимание достается пожилым людям, которые уже успели по праву заслужить только самые теплые и искренние слова. Хочу пожелать вам счастья и здоровья, активности и энергии. Пусть любые задачи оказываются выполненными, а дни проходят только с максимальной пользой. Искренне верю в то, что вы обязательно еще проявите себя и докажете, что можете быть сильными и целеустремленными. Желаю видеть в мире только позитивные грани и никогда не отчаиваться, не поддаваться дурным эмоциям. Вы можете быть самыми счастливыми, ведь вы обладаете хорошей и крепкой семьей, накопленными навыками и знаниями. Пусть багаж знаний и прожитых лет будет только достоинством. 
Старость не может быть радостным и гармоничным, спокойным периодом жизни, но это время тоже заслуживает уважения и только самых лучших чувств. Пусть болезни и физические проблемы никогда не проявляются. Ты можешь вести здоровый образ жизни, чтобы сохранить энергию и удивительный запал, использовать каждый день для чего-то полезного. Хочу пожелать счастья и успеха, уверенности в прекрасном будущем. Пусть у тебя все будет складываться только с наилучшей стороны, чтобы любые мечты оказывались совершенными, а задачи - выполненными. Желаю тебе защиты и поддержки Бога, вдохновения и стремления к полноценной жизни. Не нужно грустить, что время уходит, ведь ты еще можешь проявить себя на достойном уровне. Дорогой и родной мой человечек, смотри в будущее только с позитивом и надеждой, наслаждайся временем с семьей и внутренней гармонией. С праздником поздравляю!

$* * *$

Дорогой человек, ты уже прожил много лет, добился серьезных высот, потому заслуживаешь только позитивных слов в виде поздравлений с сегодняшним праздником. Как много дней ты проводил в смятении, не зная, что же будет дальше. Но вот, ты уже дожил до преклонного возраста, сумел обрести настоящее счастье и открыть позитивные грани судьбы. Ты по-прежнему любишь жизнь, потому стремись навстречу к ней и надейся, что все обязательно будет складываться только так, как ты этого хочешь и планируешь. Искренне желаю тебе здоровья и сил, способности проявлять заложенный потенциал и верить только в успех. Пусть жизнь дарит многочисленные возможности даже сейчас, а будущее будет позитивным. Желаю долголетия и воз- 
можности использовать каждый день с максимальной пользой. Верю в то, что ты себя еще сможешь проявить на достойном уровне. Принимай искренние поздравления!

$$
* * *
$$

Как же хочется проявить настоящее уважение в каждом слове, специально подобранном к сегодняшнему празднику. Пусть вас обязательно балует судьба и дарит многочисленные перспективы для дальнейшего развития. Желаю идеального здоровья и крепкого иммунитета, сил и активности. Близкие люди обязательно проявят внимание и заботу к тебе, окажут достойную поддержку. Цени такое отношение, ведь оно оказывается уникальным и поистине ценным, важным. Желаю достойного быта, уюта в доме, хорошей пенсии и поддержки детей, внуков. Верь в то, что судьба по-прежнему будет радовать яркими и необычными гранями, многочисленными возможностями. Цени каждый день и верь в лучшее. Принимай слова поддержки и поздравления с праздником сегодня.

\section{День российского страховщика / 6 октября}

Поздравляю с Днем страховщика! Желаю вам застраховать всех и вся, причем чтобы страховой случай никогда не наступил! Пусть среди ваших клиентов будут представительные серьезные люди, пусть желание защитить себя и свое имущество страховкой у граждан только возрастает! Успешности вам в работе и по жизни!

\section{$* * *$}

Поздравляю тебя с великолепным праздником, с Днем страховщика! Ты всегда спешишь на помощь к обычным людям для того чтобы обезопасить их имущество и даже жизнь. 
Страховка в нынешние времена необходима и мы благодарим тебя за твои старания и силы сделать жизнь простого народа безопаснее. Пусть тебе всегда улыбается удача, чтобы ты был подстрахован от далеких невзгод. Счастья тебе и благодати!

Страхование - та мера, которая уберегает от разорения в момент непредвиденных обстоятельств. Она в первую очередь способствует материальной поддержке и позволяет избежать глубоких душевных потрясений. А ты - как ангел, который своевременно предлагает выход из затруднительной ситуации. Оставайся всегда целеустремленной, благожелательной, улыбчивой. Пускай год от года множатся добрые отзывы о тебе! Пускай небо улыбается ясно и широко! Пускай ровным и гладким будет твой путь! С Днем страховщика!

$* * *$

Ура! Сегодня просто замечательный праздник - день страховщика! Поздравляю тебя и желаю застраховать себя от искренней любви, огромного счастья, большого богатства, крепкого здоровья, хорошего настроения и получить выплаты по всем этим полисам в самое ближайшее время! С праздником тебя, дружище! Пусть все будет в лучшем виде!

$* * *$

Наши виновники торжества - представители страховой компании. Они страхуют влюбленных от несчастной любви, поэтов от затмения луны, прохожих от любителей поживиться, а нас страхуют от скуки. Так выпьем же за их здоровье! С праздником! 
Страховщик - это тот человек, который помогает нам уберечь от беды то, что нам дорого. Сегодня можно застраховать свою жизнь и здоровье, дом, путешествие или домашнего любимца... Как можно не поблагодарить за труд людей, помогающих обрести уверенность в завтрашнем дне? С праздником вас, дорогие страховщики, спасибо за вашу работу и успехов в вашем труде. Пусть жизненные катаклизмы не встречаются на вашем пути!

\section{$* * *$}

Уважаемые страховщики! Примите поздравления с вашим днем, объявленного таковым в знак признания ваших заслуг перед обществом! Ведь страхование - одна из самых важных социальных составляющих современности. Незастрахованное лицо в гораздо большей степени подвержено рискам, а имущество, которое не позаботились застраховать его владельцы, становится просто опасным. Так что все звучащие сегодня в ваш адрес добрые слова целиком и полностью оправданы. Пускай же в вашей жизни будет как можно больше франшиз и как можно меньше выплат! С праздником, уважаемые страховщики!

\section{Ноябрь}

\section{День народного единства / 4 ноября}

В День народного единства хочется пожелать уважения друг к другу, добра, понимания и милосердия, искренних отношений и великодушия. Пусть наш народ помнит наши корни, наши подвиги, нашу землю и великое становление. Пусть каждый из нас осознает и ощущает всю мощь единого народа, силу взаимовыручки и дружеской помощи. 
Уважаемые коллеги! Поздравляю вас с Днем народного единства. Он отмечается в память о судьбоносных исторических событиях 1612 года, когда сплоченность и патриотизм нашего народа помогли отстоять независимость Отечества и укрепить российскую государственность.

Сегодня от нашего единства и гражданской ответственности зависит будущее России, успех модернизации страны и благополучия общества.

Желаю вам здоровья, удачи в делах, благополучия и всего самого доброго!

\section{$* * *$}

Поздравляю вас с праздником - Днем народного единства.

Россия всегда была крепка традициями народного единения и сплоченности вокруг общих, больших целей, во имя свободы и независимости Отечества. И по праву гордится многими поколениями своих верных сынов, которые вписали незабываемые страницы в летопись ее ратных побед и трудовых свершений.

Мы должны быть достойны своей великой истории и честно служить на благо Отчизны, ее будущего.

Желаю вам мирного неба над головой, крепкого здоровья, успехов, удачи, любви и поддержки близких!

\section{Международный день бухгалтера / 16 ноября}

Рад, что нахожусь здесь в теплой компании и столь приятном месте и имею возможность поздравить вас с профессиональным праздником, днем бухгалтера. 
Милые дамы, вы связали свою жизнь с такой нелегкой, но интересной профессией. Ведь бухгалтерский учет - это не констатация прошлого и настоящего, а информационный ресурс будущего. Без вашего повседневного и кропотливого труда была бы немыслима экономика страны. Невозможно принимать фундаментальные решения, не владея данными, которыми владеют специалисты в сфере бухгалтерского учета. Позвольте озвучить небольшой анекдот:

«Начинающий бухгалтер после двух дней бесплодных попыток вручную свести оборотно-сальдовую ведомость, отрывается от бумаг и говорит:

- Это надо же! Мои цифры и с моими же не сходятся!»

Поэтому я очень рад, что в бухгалтерии собрались такие опытные и ответственные специалисты, настоящие профессионалы своего дела!

Недаром говорят: «Бухгалтерия - это триумф разума над математикой», и как людям, работающим с цифрами, больше всего хочется пожелать вам именно цифровых радостей: 365 дней без обид и разочарований, 365 ночей без слез, 52 недели отличного настроения и только красочных впечатлений, 12 месяцев без болезней, ссор и несчастий. А также целый год радости, любви, удачи, удовольствия и самых лучших и радостных событий!

\section{$* * *$}

Уважаемые коллеги! Рад, что нахожусь здесь в теплой компании и столь приятном месте и имею возможность поздравить вас с профессиональным праздником. Спешу обрадовать вас, его вы можете отмечать бессчетное количество раз, 16 ноября это Международный день бухгалтера. Знаю, еще существует день 
Московского бухгалтера. Может быть, вам стоит утвердить также день (указать город) бухгалтера?

Еще раз примите искренние поздравления! Пусть это знаменательный день одарит каждого из вас хорошим настроением, добавив в дебет новых сил и творческих идей! Пусть с каждым годом ряды вашего (указать) пополняют молодые перспективные специалисты, и крепнет статус вашего (указать)! Всем вам, прекрасные дамы, желаю профессионального роста, признания заслуг и, самое главное, здоровья и семейного благополучия!

\section{Декабрь}

\section{День Конституции РФ / 12 декабря}

День Конституции РФ - это праздник государственной важности, праздник для каждого гражданина великой страны. Это наш общий праздник! Именно в этот день был принят основной закон нашего государства, который закрепляет интересы каждого гражданина и является фундаментом демократического развития российского общества. Конституция дает нам полное право чувствовать себя гарантированно защищенными, поэтому поздравляю вас, граждане великой России, с Днем наших свобод и привилегий!

$$
* * *
$$

Дорогие коллеги!

Поздравляю вас с Днем Конституции Российской Федерации! 12 декабря 1993 года по результатам всенародного голосования была принята Конституция РФ. Впервые в истории России мы получили основной закон, одобренный большинством граждан страны путем свободного волеизъявления. 
Конституция России закрепила основы демократического устройства страны, признала высшей ценностью человека, его права и свободы. Принятие нового основного закона придало мощный импульс для развития и укрепления политической, общественной, экономической и социальной систем государства.

В этот великий день для нашей страны желаю вам счастья, здоровья, благополучия и успехов во всех начинаниях!

Продолжение следует... 
Для заметок 
Вафин Эдуард Яфасович

\section{Золотые слова}

\section{Toм 1}

Серия

«Золотое сечение жизни»

Компьютерная верстка

M.A. Axмеmoва

Подписано в печать 31.05.2017.

Бумага офсетная. Печать офсетная.

Формат 60x84 1/16. Гарнитура «Times New Roman». Усл. печ. л. 11,62.

Уч.-изд. л. 6,35. Тираж 20000 экз. Заказ 343/5

Отпечатано в типографии

Издательства Казанского университета

420008, г. Казань, ул. Профессора Нужина, 1/37

тел. (843) 233-73-59, 233-73-28 